\title{
Building Soft Skills for Employability
}

This book is among the first of its kind to comprehensively examine the implementation of soft skills in universities in the developing country, Vietnam. The context is unique as the implementation is taking place within the distinctive socio-economic, cultural and political characteristics of the country, and amidst several simultaneously-executed educational reforms.

Tran lays down the foundation for discussion by providing readers with a comprehensive review of how soft skills implementation has come into existence in higher education across the globe, before diving into the implementation of soft skills in Vietnamese universities. He goes on to highlight the interesting differences in the conceptualization of soft skills between Vietnamese universities and those in the West.

The book depicts and compares how university leaders and managers tackle contextual factors, submit to constraints enforced by political forces, and how they use institutional advantages available for implementation. It goes further to examine how personal and contextual factors affect teachers' and students' engagement with the implementation, and highlights the role of work-integrated learning and extra-curricular activities in developing soft skills for students. Finally, the book investigates the contribution of external stakeholders, such as alumni, employers, skills experts, and local authorities to the implementation, and obstacles that prevent their participation.

This book will be a valuable reference for the implementation of soft skills in higher education around the world.

Tran Le Huu Nghia is currently teaching at the Faculty of Education, Monash University (Australia). He is also an honorary researcher at Ton Duc Thang University (Vietnam). He worked for eight years in the Vietnamese higher education sector prior to coming to Australia where he worked as a research fellow for Deakin University and Swinburne University of Technology. He completed the Master of Lifelong Learning: Policy and Management (2007-2009), a program coordinated by three prestigious European universities: Aarhus University (Denmark), Bilbao University (Spain), and the Institute of Education (the United Kingdom). Then as an Endeavour Postgraduate Awardee (2012-2016), he completed his $\mathrm{PhD}$, with a focus on higher education studies, at the University of Melbourne, Australia. He has produced several research outputs, including articles in high impact journals such as Higher Education, Teaching and Teacher Education, Teaching in Higher Education, Journal of Education and Work, and International Journal of Education Development. His research interests include teaching and learning for employability, teacher education, international education, and teaching English as a second language. 


\section{Routledge Research in Higher Education}

The Phenomenological Heart of Teaching and Learning

Theory, Research, and Practice in Higher Education

Katherine H. Greenberg, Brian K. Sohn, Neil B. Greenberg, Howard R. Pollio, Sandra P. Thomas, and John T. Smith

The Tenure-Track Process for Chicana and Latina Faculty Experiences of Resisting and Persisting in the Academy

Edited by Patricia A. Pérez

Higher Education in Nepal

Policies and Perspectives

Edited by Krishna Bista, Shyam Sharma, and Rosalind Latiner Raby

Race, Law, and Higher Education in the Colorblind Era

Critical Investigations into Race-Related Supreme Court Disputes

Hoang Vu Tran

Post-Recession Community College Reform

A Decade of Experimentation

Chet Jordan and Anthony G. Picciano

Building Soft Skills for Employability

Challenges and Practices in Vietnam

Tran Le Hun Nghia

Life for the Academic in the Neoliberal University

Alpesh Maisuria and Svenja Helmes

The Doctorate Experience in Europe and Beyond

Supervision, Languages, Identities

Michael Byram and Maria Stoicheva

For more information about this series, please visit: www.routledge.com/Routledge-

Research-in-Higher-Education/book-series/RRHE 


\section{Building Soft Skills for Employability}

Challenges and Practices in Vietnam

\section{Tran Le Huu Nghia}


First published 2020

by Routledge

2 Park Square, Milton Park, Abingdon, Oxon OXI4 4RN

and by Routledge

52 Vanderbilt Avenue, New York, NY 10017

Routledge is an imprint of the Taylor \& Francis Group, an informa business

(C) 2020 Tran Le Huu Nghia

The right of Tran Le Huu Nghia to be identified as author of this work has been asserted by him in accordance with sections 77 and 78 of the Copyright, Designs and Patents Act 1988.

All rights reserved. No part of this book may be reprinted or reproduced or utilised in any form or by any electronic, mechanical, or other means, now known or hereafter invented, including photocopying and recording, or in any information storage or retrieval system, without permission in writing from the publishers

Trademark notice: Product or corporate names may be trademarks or registered trademarks, and are used only for identification and explanation without intent to infringe.

British Library Cataloguing in Publication Data

A catalogue record for this book is available from the British Library

Library of Congress Cataloging-in-Publication Data

A catalog record for this book has been requested

ISBN: 978-0-367-22703-6 (hbk)

ISBN: 978-0-429-27649-1 (ebk)

Typeset in Galliard

by Taylor \& Francis Books 
This book is dedicated to

Emeritus Professor Peter McPhee

The University of Melbourne, Australia

Professor Sophia Arkoudis

The University of Melbourne, Australia

Doctor Ryan Naylor

La Trobe University, Australia

Thank you for your guidance in my first steps into academia. 
$\Longrightarrow$ Taylor \& Francis

Taylor \& Francis Group

http://taylorandfrancis.com 


\section{Contents}

List of tables

viii

Acknowledgements

Introduction: Soft skills and graduate employability

1 The surge in developing soft skills for students in higher education $\quad 1$

2 Soft-skills implementation: A literature review 18

3 The context of soft-skills implementation in Vietnamese universities

4 Models for the development of soft skills for students in Vietnamese universities

5 Contextual factors and leadership for soft-skills policy implementation: Lessons from two Vietnamese universities

6 Teaching soft skills in Vietnamese universities: Teachers' beliefs, behaviors, and influential factors

7 Assessing soft skills: Practices and challenges

8 The contribution of internships to students' development of employability

9 Students' experience with developing soft skills via participation in extracurricular activities

10 External stakeholders' roles in developing soft skills in Vietnamese universities

11 Students' participation and engagement with soft-skills development

12 Building soft skills for employability: The way ahead 


\section{Tables}

1.1 Terms referring to soft skills in some countries 1

1.2 Different soft-skills frameworks for the $21^{\text {st }}$ century 6

2.1 Top 10 soft skills selected by Australian university groups 23

2.2 Approaches to teaching generic graduate attributes 31

2.3 Levels of soft-skills implementation and respective tasks 36

3.1 Some indicators of the Vietnamese economy 42

3.2 Statistics of Vietnamese higher education from 2006-2017 48

$\begin{array}{ll}4.1 \text { A summary of participants } & 65\end{array}$

4.2 Soft-skills-implementation models in Vietnamese universities 71

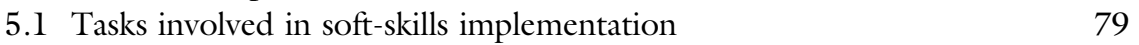

$\begin{array}{ll}5.2 \text { Participants and universities } & 83\end{array}$

$\begin{array}{ll}\text { 6.1 A summary of participants } & 102\end{array}$

$\begin{array}{ll}\text { 6.2 Teachers' beliefs about teaching soft skills } & 109\end{array}$

$\begin{array}{ll}\text { 6.3 Teachers' engagement with teaching soft skills } & 110\end{array}$

6.4 Factors influencing teachers' engagement with
teaching soft skills

$\begin{array}{ll}7.1 \text { A summary of participants } & 122\end{array}$

9.1 Contribution of extra-curricular activities participation to students' employability skills

9.2 Frequency of organizing some types of extra-curricular $\begin{array}{ll}\text { activities and student engagement } & 167\end{array}$

$\begin{array}{ll}\text { 10.1 A summary of participants and universities } & 177\end{array}$

$\begin{array}{ll}10.2 & \text { Activities that alumni can participate in } \\ 184\end{array}$

10.3 Alumni's participation in soft-skills-development activities for current students

10.4 The influence of certain factors on alumni's $\begin{array}{ll}\text { participation intention } & 185\end{array}$

11.1 Participants' information 196

11.2 Students' perception of the importance of soft skills 197

11.3 Availability of soft-skills development activities in Vietnamese universities $\quad 199$

11.4 Students' participation in soft-skills development activities 200 
11.5 Student engagement with soft-skills development

11.6 Factors influencing student engagement with soft-skills development 


\section{Acknowledgements}

This book is a combination of my doctoral dissertation and follow-up studies.

I cannot express enough thanks to my academic supervisors, academic committee, and researchers at the Centre for the Study of Higher Education (CSHE), University of Melbourne (Australia). I sincerely appreciate the learning opportunities provided by all of you.

My gratitude is also to the Australian Government's Department of Education and Training and the Department for Management of Science and Technology Development, Ton Duc Thang University (Vietnam). Without the Endeavour Postgraduate Award and your generous financial assistance, respectively, my doctoral dissertation and follow-up studies would not have been executed.

Foremost, this book project could not have been accomplished without the participants' kind support. Thank you for the time and useful data that you provided for the studies. All of your perspectives have been taken into account to generate insights into what is going on with developing soft skills for graduates' employability.

Finally, my heartfelt thanks are to my family, colleagues, friends and students. Thank you for standing by my side when the times got rough. 


\section{Introduction}

\section{Soft skills and graduate employability}

Some decades ago, possessing a university credential could guarantee graduates a permanent job with which they could climb the career ladder. However, in our contemporary society, that scenario has completely changed. A university credential alone can no longer afford graduates a permanent job. This situation appears to have resulted from some key factors.

First, knowledge expansion and technological advancement have caused constant changes in skill demands in the labor market. It is estimated that knowledge doubled every century up to 1900; that time span reduced to 25 years after World War II, and nowadays, new knowledge doubles every 13 months, on average, with nanotechnology knowledge doubling every two years and clinical knowledge every 18 months (Dehkord, Samimi, Alivand, \& Sani, 2017). The spread of the Internet is one of the major causes of the widespread distribution of knowledge (Schilling, 2010). Likewise, it is easy to observe that new technologies, equipment, and devices are being invented for the workplace at an unprecedented speed (Rossi, 2017; Susskind \& Susskind, 2015). In such a climate, university curricula, which are usually framed within three to four academic years, cannot hope to include and impart all of the new knowledge and skills needed for the modern workplace. Even if universities could do so, graduates are unlikely to master all the knowledge and skills required for work by the time of their graduation, because their professional expertise needs time to grow within a community of practice. Unfortunately, employers want new employees to hit the ground running (Brunner, Zarkin, \& Yates, 2018; McMurray, Dutton, McQuaid, \& Richard, 2016; Stevens \& Norman, 2016) so that they can spend less on training them (Lindorff, 2011; Tran, 2018). Consequently, only prospective employees who are able to demonstrate their capability, in addition to a university credential, can convince employers to offer them a job.

Second, the expansion of higher education (HE) has offered more learning opportunities for all who want a higher education, resulting in an increase in the number of graduates. For example, in a recent paper, Yang (2018) reported that in China the student $\mathrm{HE}$ enrollments increased from 936,690 in 1999 to $3,261,081$ in 2009 . By the end of this period, approximately 19 to $27 \%$ of graduates could not secure a job at their education level, despite a high economic growth rate in the country. In the same period, about $48 \%$ of four-year college graduates in the United States of America (USA) were not employed in jobs that 
require a degree (Vedder, Denhart, \& Robe, 2013). The situation is no better in the United Kingdom (UK) either, where the Office for National Statistics reports that graduate underemployment has risen from $37 \%$ in 2001 to $47 \%$ in 2013 (cited in Mok \& Jiang, 2018). In 2018, the graduate unemployment rate in Spain was 15.5\%, France 9.2\%, and Finland 7.6\% (The Statistics Portal, 2018). Although graduate unemployment could be caused by economic recession, an over-supply of graduates appears to be the main cause because all of the mentioned countries have strong and relatively stable economies.

Third, labor-market realities now are characterized by constant changes with increasing complexities and career mobility. Permanent jobs are diminishing while precarious ones are increasing (Lewchuk, 2017; Maciejewska, Mrozowicki, \& Piasna, 2016). For example, in 1976, the percentage of full-time employees in Australia and Canada was $85.4 \%$ and $87.5 \%$, respectively; by 2015 the figures had dropped to $73.7 \%$ and $81.9 \%$, respectively (Lewchuk, 2017). In Germany, between 2000 and 2010, the number of people with full-time jobs reduced by approximately 2.55 million, whereas the number of people with part-time jobs increased by 1.83 million (Lehndorff, 2016). Such a change in work arrangement means that graduates move from job to job or from one organization to another before they land a permanent employment position, possibly when their expertise is highly appraised. During the education-to-work and work-to-work transition periods, graduates need non-technical skills that enable them to navigate the world of work, identify employment opportunities relevant to their expertise, and demonstrate their capabilities to prospective employers before they can use their technical expertise for their work.

Fourth, the change in the nature of work and how work is carried out also reduces the value of university credentials. In our modern workplace, work is becoming more complex as it involves knowledge and skills from different disciplines (Bajada \& Trayler, 2013; Ivanaj \& Ivanaj, 2010). It is the norm that employees need to be capable of working individually and in a team to complete projects. Work outcomes are often the combination of the expertise of all people involved rather than reliant on individual expertise. All of this means that employees need both technical and non-technical skills and/or authentic work experience, not merely a university credential, to perform the job properly.

In response to these changes, $\mathrm{HE}$ institutions worldwide are investing in helping their students develop skills that enhance their employment and career-development prospects, creating a so-called employability agenda in HE. Employability skills are understood as "a set of achievements-skills, understanding and personal attributesthat makes graduates more likely to gain employment and be successful in their chosen occupations, which benefits themselves, the workforce, the community and the economy" (Yorke, 2006, p. 23). These skills help students "discern, acquire, adapt and continually enhance the skills, understandings and personal attributes that make them more likely to find and create meaningful paid and unpaid work that benefits themselves, the workforce, the community and the economy" (Oliver, 2015, p. 56). These snapshots of employability perspectives suggest that employability is not static but evolves throughout one's life. Therefore, graduates need to be able to adapt 
to all changes they are exposed to and learn continuously at work so that they can remain employable amidst the ups and downs of the labor market.

There are several proposed frameworks of graduate employability (for example, Clarke, 2017; Fugate, Kinicki, \& Ashforth, 2004; McQuaid \& Lindsay, 2005; Tomlinson, 2017) that comprise several types of capital, which can be developed via learning and work experience:

- Human capital: Specialized knowledge and skills, soft skills and attributes as well as socio-physical features such as gender, age, race, marital status, etc.

- Social capital: Social relationships, memberships and associations to people or organizations.

- Cultural capital: Understanding of cultures or practices in different contexts.

- Psychological capital: Psychological qualities beneficial for career development such as resilience, flexibility, self-efficacy, adaptability.

- Identity capital: Formation of work identities or personal investment in employment.

Despite being classified into several components, employability capital appears to be the combination of two sets of skills: technical and non-technical. The former includes skills distinctive to a discipline-i.e., specialized skills. The technical skills of a discipline can be homogenous between institutions in a country, or even across countries. The latter can be described as transferable, non-disciplinespecific skills that may be achieved through learning and can be applied in study, work, and life contexts (Tertiary Education Quality and Standards Agency, 2013). They are also known as soft skills, generic skills, generic graduate attributes, and transferable skills (Bowman, 2010; Maria, 2016).

Looking back to the employability capital above, soft skills are dominantly composed of these types of capital. Thus, soft skills appear to be a significant determinant of employment outcomes. They help separate employable and unemployable job applicants or distinguish capable employees, who should be invested in for the future, from those who are less capable. Indeed, an abundance of studies indicate that employers are looking for soft skills in their prospective employees. For example, Brunner et al. (2018) analyzed the content of 199 entrylevel employment advertisements posted to the Public Relations Society of America Job Center to find out what employers were looking for. They concluded that employers were not only looking for technical skills but also for soft skills, such as time management, deadline orientation, and collaboration. Using the same method, plus interviews and focus groups, Stevens and Norman (2016) analyzed 543 job advertisements in New Zealand to explore what capabilities employers needed from IT graduates. They found that employers were concerned about graduates' soft skills related to their ability to work in teams, serve customers, and function well in a business environment, and that employers often make recruitment decisions based on graduates' personal qualities. Framing their study within the context of the business discipline, McMurray et al. (2016) found that when recruiting graduates, employers paid attention to their personal attitudes, 
employability skills, relevant work experience, and degree results. They found that employers favored transferable skills such as trustworthiness, reliability, motivation, communication skills, and a willingness to learn.

Several studies also suggest that soft skills work to graduates' advantage when they apply for jobs, or in their career development once they are in a career. A study conducted by Stanford Research Institute and Carnegie Melon Foundation found that $75 \%$ of long-term job success depends on soft skills and only $25 \%$ on technical knowledge (Litecky, Arnett, \& Prabhakar, 2004, p. 69). In another study conducted in the UK, Nickson, Warhurst, Commander, Hurrell, and Cullen (2012) surveyed 173 clothing, footwear, and leather retailers about what influenced their hiring decisions. The results showed that job applicants' personalities (79.7\%) and appearance $(68.2 \%)$ were much more important for their decisions than the applicants' work experience (41.1\%) and qualifications (4.6\%). Moving away from the contribution of soft skills to graduates' employment, Gayani Fernando, Amaratunga, and Haigh (2014) explored what contributed to women's career success. They found that although success can be affected by age and gender, it depended more on soft skills than technical skills. Shaping the study in an opposite direction, Eisner (2010) found that a lack of soft skills is the key reason for employees being fired.

Against numerous studies that support the importance of soft skills in one's career development, Groh, Krishnan, McKenzie, and Vishwanath (2016) found that training in soft skills, as part of the World Bank's Jordan NOW pilot programs, did not increase possibilities for Jordanian female youth to secure jobs. However, this training was delivered within 45 hours over a nine-day period, which is not meaningful for developing soft skills as these skills need time and practice to grow (Bowman, 2010; Gonczi, 2006). The study suggests that training students in soft skills must be conducted methodologically rather than adopting a rushed, practical approach only to help students get a job. It could also be that the soft skills training in the pilot programs was not localized enough to enable participants to meet local employers' expectations.

The literature on soft-skills training, which is mostly derived from the Western English-speaking context, shows a diversity of approaches, initiatives, and activities used to help students develop these skills, depending on institutional contexts. For example, soft skills can be imparted to students via add-on units at the beginning of a degree course, or they can be integrated into the curriculum and delivered simultaneously with technical skills (Al-Mahmood \& Gruba, 2007; Barrie, Hughes, Smith, \& Thomson, 2009). They can also be developed by work-integrated learning, community service, or extracurricular activities (ECAs) (Jackson, 2018; Osman, 2011; Tran, 2017a). However, research has consistently pointed out that universities have not invested enough, academics are disengaged, and students overlook developing soft skills (Barrie et al., 2009; de la Harpe \& David, 2012; Jones, 2009; Tran, 2017a, 2017b). All of this means that, contrary to the increasing importance of soft skills in the labor market, the supply side (i.e., student, academic, and the university in general) has not developed these skills to meet the needs of the demand side. 
In short, current labor-market realities are becoming complex and require graduates to possess more than credentials and technical knowledge and skills. Soft skills are largely found to contribute to graduates' success in securing a first job and to thrive in their careers. However, it seems that soft skills training in HE is fragmented and is often disregarded by some stakeholders. It is also suggested that the implementation of soft skills in HE depends on contextual factors. For these reasons, it is vital to examine how soft skills are developed to enhance students' employability within certain HE contexts.

\section{The focus of this book}

This book reports on how Vietnamese universities are developing soft skills as a strategy to build employability for their students and identify influencers of the implementation. In this book, soft skills are defined broadly as non-disciplinary skills that may be achieved through learning and be applied in study, work, and life contexts. As noted above, soft-skills implementation is context-dependent, but most studies related to soft-skills development in $\mathrm{HE}$ have been conducted in Western English-speaking countries. For this reason, Vietnam, a developing nonEnglish-speaking country with a socioeconomic, cultural, and political context completely different from the West, provides an interesting case to expand the investigation of soft-skills implementation beyond the Western HE context.

Developing students' soft skills — as part of HE learning outcomes-has recently become a priority for Vietnamese universities. It is the response of Vietnamese universities to address the need of a skilled workforce as employers lament the shortage of soft skills in graduates (Bodewig \& Badiani-Magnusson, 2014; Truong, Laura, \& Shaw, 2018). Without a skilled workforce, the country will not be able to sustain its high socioeconomic growth rate (Anwar \& Nguyen, 2014; Trinh \& Doan, 2018) and compete in the process of regionalization in the Southeast Asian region (Jurje \& Lavenex, 2015; Suci, Asmara, \& Mulatsih, 2016; Tran \& Nørlund, 2015). Their development of students' soft skills also derives from recent political initiatives regarding improving the quality of HE (Harman, Hayden, \& Nghi, 2010; MOET, 2010, 2013).

Unfortunately, until now, there has been a lack of research examining how Vietnamese universities have been developing students' soft skills. Few studies have attempted to identify work skills that employers need, or assess graduates' attainment of these skills, and the perceived skills gaps, from the perspectives of employers, graduates, and students (Truong \& Metzger, 2007; Tran, 2018; Tran, 2013; Tran \& Swierczek, 2009). In other words, the existing studies seem to focus on output rather than process. Without investigating the process, it is difficult to identify the obstacles to remove so as to improve students' learning outcomes related to soft skills and to increase their employability throughout their career trajectories. Therefore, this book sets out to investigate the implementation of soft skills in Vietnamese universities using the perspectives and experiences of key agents of the implementation: university leaders and managers, academics, students and alumni-including employers. The book includes qualitative case 
studies conducted in six Vietnamese universities (named A, B, C, D, E, and F), which represent different institutional contexts, and quantitative studies whose data were collected from a range of Vietnamese universities across the country.

This book is unique because it captures a holistic implementation of soft skills in a non-Western HE context. It highlights a number of factors influencing soft-skills implementation that have not been found in Western HE, thus complementing the existing literature and expanding our insights into soft-skills implementation in different HE contexts. Although the book is framed within one country, its value lies in its holistic investigation of the implementation across all levels of the HE system. This holistic analysis is different from other edited books that snapshot aspects of the implementation in different countries and put them in a one-book volume. This book provides important implications for moving forward with developing soft skills at the HE level in Vietnam and in other countries so that graduates can successfully obtain their first job and remain employable throughout their career trajectory.

\section{Organization of the book}

The remainder of this book is organized into 12 chapters. The first three chapters set the background contexts and practices for soft-skills development in the world and in Vietnam; the next eight chapters report on practices and challenges associated with various tasks at different levels of soft-skills implementation. While focusing on presenting the findings relevant to the topic of each chapter, the author will also link these findings to the international context to highlight the differences and similarities in soft-skills implementation in Vietnam compared to other countries. The last chapter summarizes the main findings of the whole book and discusses ways to move forward with the implementation, not only for Vietnamese universities but also for others internationally. The main content for each chapter is as follows.

Chapter 1 reviews the literature to underline the importance of developing students' soft skills in the current changing landscape of HE across the globe. It also highlights the various initiatives used to develop university students' soft skills across different HE systems, institutions, and disciplines. It argues that soft skills are implemented differently across disciplines due to differences in disciplinary characteristics; between institutions due to discrepancies in institutional missions and visions; and between countries due to different sociocultural, economic, and political contexts and educational values.

Chapter 2 provides a comprehensive literature review on practices and challenges related to soft-skills implementation in HE contexts. Based on this literature review and theories related to education-policy implementation, the author presents a four-level conceptual framework for soft-skills implementation in HE:

- National level: The general context of soft-skills implementation.

- Institutional level: All mechanisms and strategies for executing the soft-skills policy. 
- Curriculum level: Setting soft skills learning objectives, teaching, and assessing these skills.

- Extracurricular level: The use of non-curricular activities for developing soft skills.

This framework will be used as a spine to link chapters in this book and guide the comparison of soft-skills implementation in Vietnamese universities with that of other countries.

Chapter 3 presents the context of soft-skills implementation in Vietnamese universities. It begins with depicting Vietnam as an emerging economy and a rapidly evolving society where there is a high demand for skilled workers to sustain its growth rate. Then it contradicts this picture by providing statistics about unemployment rates among university graduates and employers' complaints about the lack of soft skills in their employees. Against that national context, the chapter reports how Vietnamese universities are pressured by softskills-related policies issued by the central government, foremost the Ministry of Education and Training (MOET), employers' demands, and students' and the general public's expectations. The chapter concludes that it is time for Vietnamese universities to put forth efforts to develop students' soft skills by taking into account available institutional advantages and tackling contextual factors.

Chapter 4 reports an analysis of interviews with 28 top- and mid-level university leaders of six Vietnamese universities about how soft skills have been implemented in their institutions. The study shows that, despite choosing different soft skills to impart, they conceptualize the implementation as developing work-readiness skills for students, either on a school-wide or university-wide scale. Methodologically, the six universities develop work-readiness for students via skills subjects and ECAs. They also encourage disciplinary teachers to embed soft skills into specialized subjects and use work-integrated learning. The study suggests that university leaders make use of all possible institutional advantages for the implementation; nonetheless, they face several obstacles, such as lack of curriculum autonomy, inexperience in policy implementation, a shortage of qualified staff, and lack of connection with external stakeholders-essential elements for successful implementation of soft skills.

Chapter 5 features the influence of institutional leadership on the success of soft-skills implementation. Comparing the deployment of comparable implementation strategies in two universities, this chapter indicates that leadership skills are essential for soft-skills implementation, especially considering differences in institutional contexts and the competition of other institutional reforms. Leadership styles may affect teacher and student engagement with executing the softskills policy. This study also points out that to implement the policy successfully, Vietnamese universities need more autonomy, accountability, and proactiveness instead of relying on regulatory bodies such as MOET. It also points out that softskills implementation is context-dependent; thus, a copy-and-paste approach will not work. 
In Chapter 6, the author will report on teachers' beliefs, engagement behaviors, and factors influencing their engagement in developing students' soft skills in Vietnamese universities. Using 41 interviews with teachers of Business Administration programs in six Vietnamese universities, and 147 responses to a survey of disciplinary teachers from 27 Vietnamese universities, the two studies in this chapter show that teachers hold different beliefs about teaching soft skills and demonstrate their engagement in different acts of teaching, and that both of these are affected by several contextual factors. Based on the findings, this chapter argues that leadership should be exercised to change teachers' beliefs about the relevance of teaching soft skills, prepare them for such a new role, incentivize them, and remove obstacles so that they can engage with teaching these skills with confidence.

Chapter 7 reports a study that explores the practices and challenges of assessing students' soft skills in the Business Administration programs of six Vietnamese universities. Content analysis of interviews with 41 teachers of skills subjects and specialized subjects reveals that teachers are organizing different formative and summative soft-skills-assessment activities. Unfortunately, the analysis indicates that their practices are fragmented across subjects in the curriculum. Teachers' beliefs regarding their roles in the university, expertise in assessments, and several contextual factors are found to influence their assessment practices. The chapter argues that leadership should be exercised more effectively in order to remove obstacles and engage teachers with assessing soft skills, which will yield a washback effect on students' learning of these skills.

Chapter 8 presents a study that examines the contribution of internship experience on students' development of employability, including soft skills. Using the perspectives of 28 student interns, the study reveals that internships can help students develop many soft skills and technical skills, as well as the professional understanding and attitudes necessary for their future employment. It also reports challenges that hinder the effectiveness of this form of work-integrated learning experience. Students' awareness of the importance of the internship(s), collaboration between the university and industry, the role of the mentor, student efforts, etc. are identified as factors that influence the effectiveness of internships. The chapter discusses ways to improve the effectiveness of organizing student internships.

Chapter 9 reports a mixed-methods study about the effectiveness of developing soft skills for students via ECAs. Using six interviews with leaders of the Youth Union and associates, which are primarily in charge of organizing ECAs for students in Vietnamese universities, 18 interviews with current students, and responses to a survey of 423 students, the study suggests that these activities can contribute to the development of soft skills. However, the effectiveness of this initiative appears to depend greatly on student engagement, which is found to be associated with: (i) their beliefs about the benefits of participating in ECAs; (ii) their ability to balance formal education activities, part-time work, and ECAs; (iii) the availability of information about these activities; and (iv) the professional organization of these activities. 
Chapter 10 offers two complementary studies that explore the contribution of external stakeholders to students' soft-skills development. Using 69 university leaders' and teachers' perspectives, the qualitative study, with a focus on the Business Administration of six universities, reports that external stakeholders can take part in different tasks to impart soft skills to students. However, they find that the involvement of external stakeholders depends greatly on institutional leadership, existing industry networks, and these stakeholders' availability. The quantitative study, with participation of 154 alumni, shows that they are willing to help develop soft skills for current students in different activities. However, several factors prevent them from participating - most influentially, lack of time, not being invited by the university, fear of bureaucratic practices in the university, and a lack of experience in curriculum or program development for such activities. The chapter argues that Vietnamese university leaders need to approach external stakeholders more proactively in order to negotiate how they can help current students develop soft skills.

Chapter 11 features student engagement with soft-skills development. The analysis of 461 responses to a survey and 18 interviews with current students from six universities shows that students are highly aware of the importance of soft skills to their future work and life. They tend to develop soft skills via non-curricular activities more than curriculum-based activities. They also demonstrate a high level of cognitive engagement with developing soft skills, but this does not translate so much into concrete behaviors. The study reveals that their engagement was affected by: (i) personal beliefs about whether these activities related to their selfinterest; (ii) controlling factors such as time, effort, and cost; and (iii) third-party encouragement. The chapter argues that Vietnamese universities should focus on organizing suitable soft-skills activities that meet students' interests rather than basing them on their own perspectives.

Chapter 12 accentuates lessons for soft-skills implementation learned from the case study of Vietnamese universities. It argues that contextual factors significantly shape the development of these skills. It summarizes the key challenges to implementation presented in the previous chapters. Based on the findings, it discusses a number of initiatives so that Vietnamese universities in particular, and universities across the globe in general, can consider advancing the implementation of soft skills in their institutions. The chapter also acknowledges some limitations of the book and some directions for future studies.

\section{References}

Al-Mahmood, R., \& Gruba, P. (2007). Approaches to the implementation of generic graduate attributes in Australian ICT undergraduate education. Computer Science Education, 17(3), 171-185.

Anwar, S., \& Nguyen, L. P. (2014). Is foreign direct investment productive? A case study of the regions of Vietnam. Journal of Business Research, 67(7), 1376-1387.

Bajada, C., \& Trayler, R. (2013). Interdisciplinary business education: Curriculum through collaboration. Education + Training, 55(4/5), 385-402. 
Barrie, S., Hughes, C., Smith, C., \& Thomson, K. (2009). The national graduate attributes project: Key issues to consider in the renewal of learning and teaching experiences to foster graduate attributes. Sydney: The University of Sydney.

Bodewig, C., \& Badiani-Magnusson, R. (2014). Skilling up Vietnam: Preparing the workforce for a modern market economy. Washington, DC: World Bank Publications.

Bowman, K. (2010). Background paper for the AQF Council on generic skills. Retrieved from: www.voced.edu.au/content/ngv\%3A46853

Brunner, B. R., Zarkin, K., \& Yates, B. L. (2018). What do employers want? What should faculty teach? A content analysis of entry-level employment ads in public relations. Retrieved from https://bit.ly/2BOJj4x

Clarke, M. (2017). Rethinking graduate employability: The role of capital, individual attributes and context. Studies in Higher Education, 43(11), 1923-1937.

de la Harpe, B., \& David, C. (2012). Major influences on the teaching and assessment of graduate attributes. Higher Education Research \& Development, 31(4), 493-510.

Dehkord, F. K., Samimi, M., Alivand, R., \& Sani, E. A. (2017). An examination and assessment of knowledge management maturity in Karaj municipality. Journal of Ecophysiology and Occupational Health, 17(1-2), 34-39.

Eisner, S. (2010). Grave new world? Workplace skills for today's college graduates. American Journal of Business Education, 3(9), 27-50.

Fugate, M., Kinicki, A. J., \& Ashforth, B. E. (2004). Employability: A psycho-social construct, its dimensions, and applications. Journal of Vocational Behavior, 65(1), 14-38.

Gayani Fernando, N., Amaratunga, D., \& Haigh, R. (2014). The career advancement of the professional women in the UK construction industry: The career success factors. Journal of Engineering, Design and Technology, 12(1), 53-70.

Gonczi, A. (2006). The OECD: Its role in the key competencies debate and in the promotion of lifelong learning. In P. Hager \& S. Holland (Eds.), Graduate attributes, learning and employability (pp. 105-124). Dordrecht: Springer.

Groh, M., Krishnan, N., McKenzie, D., \& Vishwanath, T. (2016). The impact of soft skills training on female youth employment: Evidence from a randomized experiment in Jordan. IZA Journal of Labor \& Development, 5(1). doi: 10.1186/s40175-016-0055-9

Harman, G., Hayden, M., \& Nghi, P. T. (2010). Higher education in Vietnam: Reform, challenges and priorities. New York: Springer.

Ivanaj, V., \& Ivanaj, S. (2010). The contribution of interdisciplinary skills to the sustainability of business: When artists, engineers, and managers work together to serve enterprises. In J. A. F. Stoner \& C. Wankel (Eds.) Global sustainability as a business imperative (pp. 91-109). New York: Palgrave Macmillan.

Jackson, D. (2018). Developing graduate career readiness in Australia: Shifting from extracurricular internships to work-integrated learning. International Journal of Work-Integrated Learning, 19(1), 23-35.

Jones, A. (2009). Generic attributes as espoused theory: The importance of context. Higher Education, 58(2), 175-191.

Jurje, F., \& Lavenex, S. (2015). ASEAN Economic Community: What model for labour mobility? Working paper 2. NCCR-Swiss National Centre of Competence in Research. Retrieved from: www.wti.org/media/filer_public/24/f2/24f2c553-c4cc-4cc2-b670-6144e $31 \mathrm{~d} 453 \mathrm{c} / \mathrm{nccr} \_w o r k i n g \_p a p e r \_a s e a n \_j u r j e \_l a v e n e x \_. p d f$

Lehndorff, S. (2016). Internal devaluation and employment trends in Germany. In M. Myant, S. Theodoropoulou, \& A. Piasna (Eds.), Unemployment, internal devaluation and labour market deregulation in Europe (pp. 169-196). Brussels: European Trade Union Institute (ETUI). 
Lewchuk, W. (2017). Precarious jobs: Where are they, and how do they affect well-being? The Economic and Labour Relations Review, 28(3), 402-419.

Lindorff, M. (2011). Skills gaps in Australian firms. Journal of Vocational Education and Training, 63(2), 247-259.

Litecky, C. R., Arnett, K. P., \& Prabhakar, B. (2004). The paradox of soft skills versus technical skills in IS hiring. Journal of Computer Information Systems, 45(1), 69-76.

Maciejewska, M., Mrozowicki, A., \& Piasna, A. (2016). The silent and crawling crisis: International competition, labour market reforms and precarious jobs in Poland. In M. Myant, S. Theodoropoulou, \& A. Piasna (Eds.), Unemployment, internal devaluation and labour market deregulation in Europe (pp. 229-254). Brussels: European Trade Union Institute (ETUI).

Maria, C. (2016). "Lost in translation": Soft skills development in European countries. Tuning Journal for Higher Education, 3(2), 389-427. doi: 10.18543/tjhe-3(2)2016pp389-427

McMurray, S., Dutton, M., McQuaid, R., \& Richard, A. (2016). Employer demands from business graduates. Education + Training, 58(1), 112-132.

McQuaid, R. W., \& Lindsay, C. (2005). The concept of employability. Urban Studies, 42(2), 197-219.

MOET (2010). Công văn 2916/ BGDĐT-GDĐH hương dân xây dưng và công bố chuẩn đầu ra ngành đào tạo. Retrieved from http://thuvienphapluat.vn/cong-van/Giao-duc/ Cong-van-2196-BGDDT-GDDH-cong-bo-chuan-dau-ra-nganh-dao-tao-104676.aspx

MOET (2013). Công văn 2435/BGDĐT-GDĐH về việc rà soát chuẩn đầu ra và biên soạn giáo trinh. Retrieved from http://thuvienphapluat.vn/cong-van/Giao-duc/Cong-va n-2435-BGDDT-GDDH-ra-soat-chuan-dau-ra-va-bien-soan-giao-trinh-182111.aspx

Mok, K. H., \& Jiang, J. (2018). Massification of higher education and challenges for graduate employment and social mobility: East Asian experiences and sociological reflections. International Journal of Educational Development, 63(Nov), 44-51.

Nickson, D., Warhurst, C., Commander, J., Hurrell, S. A., \& Cullen, A. M. (2012). Soft skills and employability: Evidence from UK retail. Economic and Industrial Democracy, $33(1), 65-84$.

Oliver, B. (2015). Redefining graduate employability and work-integrated learning: Proposals for effective higher education in disrupted economies. Journal of Teaching and Learning for Graduate Employability, 6(1), 56-65.

Osman, K. (2011). The inculcation of generic skills through service learning experience among science student teachers. Procedia-Social and Behavioral Sciences, 18, 148-153.

Rossi, B. (2017). Technology is ready to define the future of the workplace. Information Age. 18 April. Retrieved from www.information-age.com/technology-ready-define-fu ture-workplace-123465776/

Schilling, M. A. (2010). Strategic management of technological innovation. New York: Tata McGraw-Hill Education.

Stevens, M., \& Norman, R. (2016). Industry expectations of soft skills in IT graduates: A regional survey. Paper presented at the Proceedings of the Australasian Computer Science Week Multiconference, February 2-5, Canberra, Australia.

Suci, S. C., Asmara, A., \& Mulatsih, S. (2016). The impact of globalization on economic growth in ASEAN. Bisnis \& Birokrasi Journal, 22(2), 79-87.

Susskind, R. E., \& Susskind, D. (2015). The future of the professions: How technology will transform the work of human experts. Oxford: Oxford University Press.

Tertiary Education Quality and Standards Agency (2013). Australian qualifications framework. Canberra: The Australian Qualifications Framework Council. 


\section{xxii Introduction}

The Statistics Portal (2018). Unemployment rate in member states of the European Union in June 2018. Retrieved from www.statista.com/statistics/268830/unemployment-ra te-in-eu-countries/

Tomlinson, M. (2017). Forms of graduate capital and their relationship to graduate employability. Education + Training, 59(4), 338-352.

Tran, A. N., \& Nørlund, I. (2015). Globalization, industrialization, and labor markets in Vietnam. Journal of the Asia Pacific Economy, 20(1), 143-163.

Tran, L. H. N. (2017a). Developing employability skills via extra-curricular activities in Vietnamese universities: Student engagement and inhibitors of their engagement. Journal of Education and Work, 30(8), 854-867.

Tran, L. H. N. (2017b). What hinders teachers from translating their beliefs into teaching behaviors: The case of teaching generic skills in Vietnamese universities. Teaching and Teacher Education, 64(May), 105-114.

Tran, L. H. N. (2018). Game of blames: Higher education stakeholders' perceptions of causes of Vietnamese graduates' skills gap. International Journal of Educational Development, 62(Sep), 302-312.

Tran, T. T. (2013). Limitation on the development of skills in higher education in Vietnam. Higher Education, 65(5), 631-644.

Tran, Q. T., \& Swierczek, F. W. (2009). Skills development in higher education in Vietnam. Asia Pacific Business Review, 15(4), 565-586.

Trinh, L. Q., \& Doan, H. T. T. (2018). Internationalization and the growth of Vietnamese micro, small, and medium sized enterprises: Evidence from panel quantile regressions. Journal of Asian Economics, 55(April), 71-83.

Truong, T. T. H., Laura, R. S., \& Shaw, K. (2018). The importance of developing soft skill sets for the employability of business graduates in Vietnam: A field study on selected business employers. Journal of Education and Culture Studies, 2(1), 32-45.

Truong, Q. D., \& Metzger, C. (2007). Quality of business graduates in Vietnamese institutions: Multiple perspectives. Journal of Management Development, 26(7), 629-643.

Vedder, R., Denhart, C., \& Robe, J. (2013). Why are recent college graduates underemployed? University enrollments and labour-market realities. Washington, DC: Center for College Affordability and Productivity.

Yang, L. (2018). Higher education expansion and post-college unemployment: Understanding the roles of fields of study in China. International Journal of Educational Development, 62(Sep), 62-74.

Yorke, M. (2006). Employability in higher education: What it is, what it is not. Retrieved from https://bit.ly/22VzZS0 


\section{The surge in developing soft skills for students in higher education}

Up to now, we have known that soft skills are an important component of graduate employability. Before going further, it is important to understand what soft skills are, their nature and components. This will enable us to understand the various ways to implement soft skills in higher-education institutions across the globe.

\section{What are soft skills?}

It is not easy to have a consensus on a definition of soft skills, since these skills are conceptualized differently between disciplines, contexts, and countries (see Table 1.1). For example, in Australian HE, this set of skills is often referred to as "generic graduate attributes," "generic skills," "key competencies," "soft skills," and "employability skills." They are known as "key skills" or "core skills" in the UK; "essential skills" in New Zealand; or "necessary skills," and "workplace knowhow" in the USA (Bowman, 2010; Hager \& Holland, 2006). In Vietnam, these

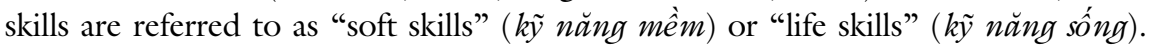
In this book, the term "soft skills" will be used as it is a common term in the literature of different disciplines and in Vietnam, the main context of this book.

Table 1.1 Terms referring to soft skills in some countries (Bowman, 2010; Cinque, 2016)

\begin{tabular}{ll}
\hline Countries & Equivalent names for soft skills \\
\hline Australia & $\begin{array}{l}\text { Generic graduate attributes, generic skills, key competencies, employability } \\
\text { skills }\end{array}$ \\
UK & Key skills, core skills, life skills, key transferable skills, cross competencies \\
USA & Necessary skills, workplace know-how \\
New Zealand & Essential skills \\
Germany & $\begin{array}{l}\text { Schlüsselkompetenzen (key competencies), Übergreifende kompetenzen } \\
\text { (general competencies) }\end{array}$ \\
Denmark & Nøglekompetence (key competencies) \\
France & Compétences transversales (transversal competencies) \\
Spain & Competencias genéricas (general competencies) \\
Vietnam & Kỹ năng sống (life skills), kỹ năng mềm (soft skills) \\
\hline
\end{tabular}




\section{The surge in developing soft skills}

Associated with different terms are a variety of definitions for soft skills. Some authors view soft skills in relation to whether these skills are innate abilities and are skeptical about whether students can be trained in them. For example, Heckman and Kautz (2012) define soft skills as personality traits, goals, motivations, and preferences that are valued in the labor market, in school, and in many other domains. Knight (2007) defines soft skills as wicked competences; others consider these skills as emotional intelligence (see Kyllonen, 2013; OECD, 2015) or non-cognitive skills, such as perseverance, sociability, and self-esteem (Heckman \& Rubinstein, 2001). Noncognitive skills and emotional skills have been found to "influence numerous measures of social outcomes, including better health, improved subjective well-being and reduced odds of engaging in conduct problems" (OECD, 2015, p. 3). Yet in reality, "soft skills include both social/interpersonal skills and [...] the capacity to work on competences, to reframe and transfer them from one field to another, even from informal to formal learning" (Cinque, 2016, p. 394).

Some organizations define soft skills from administrative and management viewpoints, distinguishing soft skills from the remainder of learning outcomes of a certain level of education. For example, using the terms "generic graduate attributes," the Higher Education Council of Australia defined soft skills as "the skills, personal attributes and values which should be acquired by all graduates, regardless of their discipline or field of study" (Treleaven \& Voola, 2008, p. 20). Likewise, Bowden et al. (2000) defined generic graduate attributes as:

... the qualities, skills and understandings a university community agrees its students should develop during their time with the institution. These attributes include but go beyond the disciplinary expertise or technical knowledge that has traditionally formed the core of most university courses. They are qualities that also prepare graduates as agents of social good in an unknown future ... (as cited in S. C. Barrie, 2007, p. 440).

In most cases, soft skills are defined in relation to technical skills. Technical skills are "those skills acquired through training and education or learned on the job and are specific to each work setting" while soft skills are "the cluster of personality traits, social graces, language skills, friendliness, and optimism that mark each one of us to varying degrees" (Litecky, Arnett, \& Prabhakar, 2004, p. 69). Robles (2012) contrasted hard skills with soft skills, in which the former is the technical expertise and knowledge needed for a job, whereas the latter includes interpersonal skills and personal attributes. Davis and Muir (2004, p. 96) defined:

... soft skills are attitudes and behaviors displayed in interactions among individuals that affect the outcomes of such encounters. These differ from hard skills, which are the technical knowledge and abilities required to perform specific job-related tasks more formally stated in job descriptions. (p. 96)

More conceptually, Weber, Finley, Crawford, and Rivera Jr (2009, p. 356) point out that soft skills are "interpersonal, human, people or behavioural skills needed 
to apply technical skills and knowledge in the workplace." Echoing this viewpoint, Laker and Powell (2011, p. 112) view soft skills as "intra-personal skills such as one's ability to manage oneself as well as interpersonal skills such as how one handles one's interactions with others."

It is also noted that some organizations or authors do not provide a concrete definition of soft skills but rather provide a list of examples of such skills for free interpretation. For example, the Malaysian Institute of Higher Learning interprets soft skills as non-academic skills such as communication, critical-thinking and problem-solving, leadership, teamwork, entrepreneurship skills, ethics and professional morals (Shakir, 2009). Mitchell, Skinner, and White (2010) consider that soft skills include leadership, self-management, conflict resolution, communication, emotional intelligence, and so on. Hager and Holland (2006) further explain that soft skills mostly cluster around human activities such as communication and working with each other, gathering and ordering information, and problem-solving (p. 2). They are seen as capable of enhancing work effectiveness, especially regarding the rapidly evolving and interconnected world we are living in now.

With the myriad terms used to refer to soft skills, as well as differences in the perspectives of researchers and governmental bodies, it is little wonder there has been a lack of consensus in coming up with a definition. Nevertheless, the importance of developing soft skills in HE as one way to enhance graduates' employability is acknowledged by all. Regardless of the availability of a definition of soft skills, it may not be applicable to the Vietnamese HE context, where some different terms have been used to refer to soft skills, albeit without any concrete definitions. Therefore, in this book, soft skills are defined broadly as non-disciplinary skills that may be achieved through learning and be applied in study, work, and life contexts. This definition allows some space to include various conceptualizations of soft skills, which could significantly influence their implementation.

\section{Nature of soft skills}

Understanding the nature of soft skills is vital for the successful implementation of these skills in a HE context. Despite there being few studies on the nature of soft skills, it seems that there is a consensus in this respect. Soft skills are found to be elusive, discipline-relating, and transferable between contexts. They cluster and complement each other. They require substantial time and practice to grow to a level where they can be used naturally.

Firstly, these skills are elusive. People have talked a lot about these skills and their importance in the modern workplace as well as in personal life. However, when it comes to providing a clear description of what they are, it is not easy at all (Knight, 2007). That partly explains why there are several definitions of soft skills, as reported above. People of different fields of study may describe these skills differently depending on which stance they hold. If they are more related to social values, they would consider these skills in terms of social benefits. Conversely, if people are business-oriented, they would view these skills in terms of socioeconomic gain. This will be further illustrated by the cases of the Tuning 


\section{The surge in developing soft skills}

Educational Structures in Europe project (Tuning) and the Assessment of Higher Education Learning Outcomes (AHELO) project below. The elusive nature of soft skills causes many difficulties for the execution of soft skills policy in HE, as stakeholders do not have a consensus on what they should teach, as well as how to teach and assess these sorts of skills.

Secondly, despite the term "generic skills" used to denote soft skills, these skills are discipline-related in the sense that the importance and balance of these skills varies across disciplines (Barrie, Hughes, Smith, \& Thomson, 2009; Jones, 2010). For example, written communication skills for students in social sciences may not be as technical and terminological as those for students in engineering. Communication and interpersonal skills are vital for journalism students, but they are less important for biotechnology students who spend most of their time working in the lab. This implies that soft skills should be taught within the disciplinary context. However, in practice, many prefer to treat soft skills as "generic" across disciplines and contexts of application possibly to ease the management of the implementation process. This may result in ineffective implementation of soft skills in educational contexts.

Thirdly, soft skills are transferable between learning and work contexts (Bridges, 1993; Hind, 1994). This characteristic reflects well the term "generic skills" in that in every learning and work context, these skills can be found. Once we master a soft skill within a particular setting, we can use it again in a different setting. For example, an IT technician can transfer problem-solving skills learned from his or her role in a bank to a textile manufacturer because most tasks would deal with computers and similar issues. However, in order to transfer these skills between the two work settings, he or she would need some time to adapt the skills to fit in with the "content" of a new work setting and focus. The problem-solving skills are the same, but the "material" on which these skills are applied is different, so they need modification. This characteristic of soft skills suggests that when developing these skills for students, activities need to be diverse so that they can flexibly practice these skills. This would enhance their ability to transfer soft skills across different work settings.

Fourthly, existing research suggests that soft skills exist as clusters of different but complementary skills which dynamically combine with each other differently in different contexts (Bowman, 2010; Gonczi, 2006; Hager \& Holland, 2006; Tuning Educational Structures in Europe, 2019). Indeed, it is difficult to imagine how a businessperson can communicate effectively to his or her clients without interpersonal skills. Likewise, teamwork may not achieve expected outcomes if team members fail to communicate with each other to discuss, negotiate, and agree on solutions to solve the problems facing them. Problem-solving ability will not suffice if it does not involve critical thinking and/or creativity. This suggests that soft skills should not be imparted skill by skill; they must be taught and assessed together rather than by single skills, preferably within the context of a discipline (Ang, D’Alessandro, \& Winzar, 2014).

Finally, soft skills take a great deal of time to develop, even one's entire life (Knight, 2007). That is why many soft skills are often classified under lifelong 
skills, which are essential for our modern life where knowledge is growing exponentially (Dehkord, Samimi, Alivand, \& Sani, 2017). The Introduction discussed a study conducted by Groh, Krishnan, McKenzie, and Vishwanath (2016) where they tested the impact of short soft-skills training courses on young Jordanian women's employment outcomes. They did not find any correlations between them. Exposed for 45 hours over a nine-day period to several soft skills might have been enough time for these women to get a general idea about what these skills were, why they were sought after by employers, and how they might affect their job applications, but it was unlikely that these women could master these skills and put them into practice. Gonczi (2006) argued that soft skills need time and practice to grow. Indeed, it is easy to validate this claim. Just imagine public-speaking skills, which are important for most businesses. Although we may read several how-to books or watch YouTube videos to learn from those who have mastered these skills, we may still end up stuttering in front of a crowd, even if we have rehearsed several times. Without regular practice, soft skills may not stay with us or be summoned for effective use when needed. This essential nature of soft skills suggests that training courses must be organized within a long enough time span to offer students numerous chances to practice the skills in order to master them.

\section{What soft skills are the most relevant for the $21^{\text {st }}$ century?}

Identifying a list of soft skills most relevant for the $21^{\text {st }}$ century is not simple because, in our rapidly changing market realities, the skills needed constantly alter. However, reviewing the frameworks of soft skills that international organizations recommend, frameworks that are based on sound research, may give us a general view about what skills should be taught to young generations so that they can function well in the modern era.

Table 1.2 shows that there is no one definitive list of generic skills. Each list has been compiled under the influence of global, local, and organizational factors. For example, in the World Health Organization list, there are soft skills that enhance human well-being (coping with emotion, stress, and empathy), whereas other lists do not emphasize these. Likewise, the list of soft skills appears to change through time, taking into account the current essential elements of society. For example, the Institute for the Future list includes several skills to enhance our ability to work with information technology (new media literary, computational thinking, virtual collaboration), an essential element of our contemporary society. Regardless of disparities, these lists share some commonalities, which can be classified, with examples, as follows:

- Basic skills: Literacy, using numbers, using technology.

- People-related skills: Communication, interpersonal, teamwork, customerservice skills. 
Table 1.2 Different soft-skills frameworks for the $21^{\text {st }}$ century (Cinque, 2016)

\begin{tabular}{lll}
\hline Organization & Year & Name \\
\hline $\begin{array}{l}\text { World Health } \\
\text { Organization } \\
\text { (WHO) }\end{array}$ & 1993 & Life skills \\
& & \\
& & \\
$\begin{array}{l}\text { Istituto per lo } \\
\text { Sviluppo della }\end{array}$ & $1994-$ & $\begin{array}{l}\text { Transversal } \\
\text { skills } \\
\text { Formazione } \\
\text { Professionale dei } \\
\text { Lavoratori }\end{array}$ \\
\end{tabular}

Organization for

2003

Economic

Co-operation

and Develop-

ment (OECD)
European Union 2006 Key competences for lifelong learning
Skills

- Decision-making and problem-solving

- Creative thinking and critical thinking

- Communication and interpersonal skills

- Self-awareness and empathy

- Coping with emotions and coping with stress

Useful to:

- Diagnose the nature of the environment and task (mainly cognitive skills)

- Relate to people and issues of a specific context (interpersonal or social skills, which is the emotional skill set, cognitive and behavioral styles, but also communication skills)

- Address, that is to "face, cope, predispose to deal with the environment and the task, both mentally and emotionally ... take action on a problem with the best chance of solving it" (be able to set goals, to develop strategies, and to build and implement action plans)

- Using tools interactively, which includes the capacity to use language, symbols and texts interactively, use knowledge and information interactively, use technology interactively

- Interacting in a socially homogenous group-i.e., relate well to others, cooperate, work in teams, manage and resolve conflicts

- Acting autonomously, which includes key competencies that empower individuals to manage their lives in meaningful and responsible ways by exercising control over their living and working conditions (for example, form and conduct life plans and personal projects, defend and assert rights, interests, limits and needs)

- Communication in the mother tongue

- Communication in foreign languages

- Mathematical competence and basic competences in science and technology

- Digital competence

- Learning to learn

- Social and civic competences

- Sense of initiative and entrepreneurship

- Cultural awareness and expression 


\begin{tabular}{|c|c|c|c|}
\hline Organization & Year & Name & Skills \\
\hline $\begin{array}{l}\text { Tuning Educa- } \\
\text { tional Structures }\end{array}$ & 2008 & $\begin{array}{l}\text { Generic } \\
\text { competences }\end{array}$ & $\begin{array}{l}\text { - Instrumental competences-i.e., cognitive } \\
\text { abilities, methodological abilities, techno- } \\
\text { logical abilities and linguistic abilities } \\
\text { - Interpersonal competences-i.e., indi- } \\
\text { vidual abilities such as social skills } \\
\text { (social interaction and cooperation) } \\
\text { - Systemic competences-i.e., abilities and } \\
\text { skills concerning whole systems (combi- } \\
\text { nation of understanding, sensibility and } \\
\text { knowledge; prior acquisition of instru- } \\
\text { mental and interpersonal competences } \\
\text { required) }\end{array}$ \\
\hline OECD & 2009 & $\begin{array}{l}21^{\text {st }} \text { century } \\
\text { skills }\end{array}$ & $\begin{array}{l}\text { - Information: "Information as source" } \\
\text { (searching, selecting, evaluating and } \\
\text { organizing) and "information as pro- } \\
\text { duct" (restructuring and modelling of } \\
\text { information and the development of } \\
\text { own ideas/knowledge) } \\
\text { - Communication: "Effective communica- } \\
\text { tion" (sharing and transmitting the results } \\
\text { or outputs of information) and "colla- } \\
\text { boration and virtual interaction" (reflect- } \\
\text { ing on others' work, creation of } \\
\text { communities) } \\
\text { Ethics: "Social responsibility" (applying } \\
\text { criteria for responsible use at personal } \\
\text { and social levels) }\end{array}$ \\
\hline $\begin{array}{l}\text { Institute for the } \\
\text { Future }\end{array}$ & 2011 & $\begin{array}{l}\text { Future work } \\
\text { skills } 2020\end{array}$ & $\begin{array}{ll}\text { - } & \text { Sense making } \\
\text { - } & \text { Social intelligence } \\
\text { - } & \text { Novel and adaptive thinking } \\
\text { - } & \text { Cross-cultural competency } \\
\text { - } & \text { Computational thinking } \\
\text { - New media literacy } \\
\text { - } \quad \text { Trans-disciplinarity } \\
\text { - } \quad \text { Design mindset } \\
\text { - } \quad \text { Cognitive load management } \\
\text { Virtual collaboration }\end{array}$ \\
\hline
\end{tabular}

This table is reproduced with written permission from the Managing Editor of Tuning Journal for Higher Education on 25 February 2019. The original work can be found in Cinque, M. (2016). "Lost in translation": Soft skills development in European countries. Tuning Journal for Higher Education, 3(2), $389-427$.

- Conceptual/thinking skills: Collecting and organizing information, problemsolving, planning and organizing, learning-to-learn skills, critical thinking, creativity.

- Personal skills and attributes: Being responsible, resourceful, flexible, having self-esteem, management skills.

- Skills related to the business world: Innovation skills, enterprise skills.

- Skills related to the community: Civic or citizenship knowledge and skills. 


\section{Soft-skills-development initiatives in higher education worldwide}

Recognizing the importance of soft skills in our modern life, international organizations, governments, and HE institutions worldwide have launched many initiatives to develop soft skills. These initiatives appear to be influenced by the socioeconomic, cultural, and political contexts of the country as well as the visions and missions of the institution.

\section{International initiatives}

On a global scale, a number of influential activities around soft-skills development have recently been initiated by supranational organizations, among which the Tuning and AHELO projects are most relevant to the HE context. Generally, despite the difference in purpose and scope, both projects highlight the importance and relevance of generic skills in current socioeconomic contexts. Furthermore, both projects take into account the differences in educational culture and tradition between education systems when tackling the issues related to $\mathrm{HE}$ learning outcomes in general and soft skills in particular.

In Europe, the Tuning project was implemented in 2000. It aimed to establish a measure to compare HE curricula across European countries (González \& Wagenaar, 2003). It has now spread to other parts of the world, forming Tuning Latin America, Tuning Africa, Tuning China, etc. (Tuning Educational Structures in Europe, 2019). It introduced the concept of competences as the basis for the learning outcomes of $\mathrm{HE}$ programs for use in the European HE space. "Learning outcomes are statements of what a learner is expected to know, understand and/or be able to demonstrate after completion of learning" and "competences represent a dynamic combination of knowledge, understanding, skills and abilities [which] will be formed in various course units and assessed at different stages" (Tuning educational structures in Europe, 2019). The project also made clear technical and generic competences. While acknowledging the importance of technical competences as the basis for university-degree programs, Tuning emphasizes that generic competences (i.e., soft skills) are becoming more relevant for students' futures in terms of employability and citizenship. During Phase 1, the project also produced a list of most relevant generic skills for each field and across fields of study, based on consultation with graduates, employers, and academics. It is also interesting to note that while Tuning attempts to create compatibility and comparability across $\mathrm{HE}$ programs in Europe, it does not look for uniformity in the degree programs or curricula but simply looks for points of reference, convergence, and common understanding. Put differently, Tuning appears to protect the rich diversity of European education, appreciates the independence of academic and subject specialists, and respects local and national authority (Tuning Educational Structures in Europe, 2019). This notion suggests that the selection and development of subject-specific and generic competences vary across disciplines, institutions, and countries depending on the bounded contexts. 
Taking a different approach, the AHELO project launched by the OECD attempted to create a new instrument to test students nearing the end of a bachelor's degree. The main rationale for the test was that current assessment methods were inadequate to meet the challenges posed by the technological changes in the $21^{\text {st }}$ century (Coates \& Richardson, 2012). The test focused on both soft and technical skills; however, for the trial, the project only focused on the economics and engineering disciplines. In terms of soft skills, the test was developed based on the adaptation of the US Collegiate Learning Assessment (Hardison \& Vilamovska, 2009). Students taking this test needed to use critical thinking, analytic reasoning, problem-solving and written communication to answer several open-ended questions about a hypothetical but realistic situation and gather necessary evidence from different sources. The results were to be used for comparing students internationally regardless of language or cultural background in order to provide data of actual quality of learning and its relevance to the labor market. The AHELO project was expected to create an impact in the HE sector, just like the Program for International Student Assessment (PISA), which is a measure to test the skills and knowledge of students at 15 years of age. The AHELO project involved $10 \mathrm{HE}$ institutions in each of the 15 participating countries across the globe, most of which are leading economies (Australia, Belgium, Columbia, Egypt, Finland, Italy, Japan, Korea, Kuwait, Mexico, the Netherlands, Norway, the Russian Federation, Sweden, and the USA). However, AHELO was critiqued to be unfit to all educational systems concerning cultural differences; thus, its reliability needed verifying (Tremblay, Lalancette, \& Roseveare, 2012). Regardless of the failure of the AHELO project, assessing HE learning outcomes is still on the OECD's agenda: a new project that evaluates HE learning outcomes was reported to follow the AHELO project (Sharma, 2015).

Contrasting the two projects with regard to their perspective towards soft skills, AHELO is more concerned with the economic aspects of soft skills whereas Tuning, launched within the framework of lifelong learning, seeks both personal and social gain. The difference appears to relate to the role of the two organizations. The OECD is an organization promoting economic development; thus, it may appear more profit-inclined in most actions. Meanwhile, the European Union (EU) plays the role of moderator of its member states with respect to cultural diversity, political complexity, and social cohesion. Such a difference between the two projects indicates different intentions behind launching programs for softskills development, and these intentions need to be examined closely.

Despite the differences, both projects converge at two points. Firstly, both are interested in and concerned with generic-skills development for HE students. This suggests that generic skills have attracted policy makers on a global scale. Secondly, both organizations are aware of cultural differences between HE systems. The AHELO project did not succeed in making the test accepted across countries due to the feasibility of administering it and difficulties in validating the reliability of the test across all HE systems. The EU does not use competences as prescriptive elements to inform the curricula of programs in the European HE space but as references and comparative elements instead. Such cultural awareness 
suggests that soft skills may be selected, prioritized, and developed differently across HE systems.

\section{National initiatives}

Nationally, in many countries, developing soft skills for university students has become a major concern of policymakers, HE leaders, and academics, and seems to be driven by political factors. The UK, Australia, New Zealand, Malaysia, Thailand, Vietnam, Korea, Japan, Canada, Denmark, Switzerland, France, and South Africa have established national qualification frameworks, which specify the learning outcomes for all levels of education in each country. At the HE level, it is observed that soft skills are included as an integral part of the learning outcomes and are linked to quality-assurance and public-funding schemes (Danish Government, 2008; Quality Assurance Agency for Higher Education, 2008; Tertiary Education Quality and Standards Agency, 2013; Thai Government, 2006; The Quality Assurance Agency for Higher Education, 2014). The influence of political factors on elevating the role of soft skills in HE will be illustrated by the cases of British and Australian higher education, as follows.

Since the 1980s, the British Government and employers have articulated the need for training students in generic, transferrable skills as a key aspect of employability. However, soft skills were not a central issue in HE at the time. Not until the Dearing Report (published in 1997) were universities encouraged to develop program specifications with intended learning outcomes including knowledge and understanding, key skills, cognitive skills, and subjectspecific skills (Atlay, 2006). Then the Framework for Higher Education Qualifications in England, Wales and Northern Ireland provided a more detailed description of knowledge, skills, and competencies that graduates of a British university should possess in terms of disciplinary knowledge and understanding, ability to apply the knowledge and understanding, communication and cognitive skills, qualities and transferable skills for employment purposes (Quality Assurance Agency for Higher Education, 2008). The Quality Assurance Agency for Higher Education (2014) in the UK has also passed the framework for $\mathrm{HE}$ qualifications and required degree-awarding bodies in the UK to comply with it.

In Australia, there have been many projects promoting the implementation of generic graduate attributes - an alternative term for soft skills in Australian HEin recent decades. In 1992, the Mayer report (Mayer, 1992) encouraged tertiary institutions to develop seven competencies for students: collecting, analyzing and organizing information; communicating ideas and information; planning and organizing activities; working with others in teams; solving problems; using mathematical ideas and techniques; and using technology. The report appeared to influence the VET (Vocational Education and Training) sector and vocationoriented universities significantly, but did not engage all Australian universities with soft-skills implementation due to the lack of a political mechanism. Then the National GAP project (2007-2008) was conducted to explore the progress 
and identify challenges to the implementation of soft skills in the Australian HE sector. The research team reported a slow and sporadic implementation across the HE system with numerous challenges along the way (Barrie, Hughes, \& Smith, 2009). The researchers recommended linking soft-skills implementation with quality assurance to boost its progress (Barrie, Hughes, Smith, \& Thomson, 2009). The Hunters and Gatherers project (2011-2013) was carried out by seven Australian universities to document the mapping of learning objectives related to soft skills in the curricula and evidence students' achievement of the objectives. This project was significant in that it urged the universities to explicitly include soft skills in the curriculum, deliver and assess them, and find ways to present their students' achievement of soft skills (Lawson et al., 2013). Most influentially, established in 2011, the Tertiary Education Quality and Standards Agency (TEQSA) issued the Australian Qualifications Framework (AQF) and Higher Education Standards Framework (HESF). TEQSA, as described on its website, "registers and assesses the performance of $\mathrm{HE}$ providers against the Higher Education Standards Framework." The "learning outcomes and assessment" section in the HESF strongly reflects the AQF, which includes soft skills as part of the HE learning outcomes. It is then possible to conclude that the arrival of the AQF and HESF has politically made soft skills an indispensable component of the Australian HE curricula.

It is also observed that the implementation of soft skills has been influenced by the socioeconomic, cultural, and political context of each country. For example, the Danish National Qualification Framework suggests that Denmark focuses on developing lifelong learning for students (Danish Government, 2008), which seems to derive from the need to better use the aging labor workforces and enhance the Danish flexicurity economic model (Bredgaard \& Madsen, 2018; Klindt, Baadsgaard, \& Jørgensen, 2017). In other words, characteristics of the labor workforce and economy may influence the selection of relevant soft skills for students to develop. Meanwhile, the Thai National Qualification Framework for Higher Education appears to require Thai universities to focus on developing moral and ethical qualities for students (Thai Government, 2006). This focus appears to be significantly influenced by Thailand being a Buddhist country and by the fact that the country is attempting to preserve "Thai wisdom" (Chaisinthop, 2014; Chansomsak \& Vale, 2008; Ma Rhea, 2018; Pimpa, 2011). As such, prominent cultural values may be taken into consideration when identifying and developing soft skills for students. In other countries, such as China, political and citizenship education is one of the central missions of the education system (Banks, 2007; Kennedy, Fairbrother, \& Zhao, 2013), suggesting that the political regime of a country also influences soft-skills implementation.

In short, the literature review suggests that while countries may engage in implementing similar initiatives for improving the quality of HE learning outcomes in general and soft skills in particular, the focus of these initiatives is influenced by the cultural, socioeconomic, and political contexts of each country. 


\section{Institutional level}

Many universities publish the mission statements and learning outcomes of their institutions, including soft skills, on their websites. It is observed that the selected soft skills may look similar in terms of word choice; however, they diverge across institutions and reflect the underpinning characteristics of that institution. For example, years after the Mayer competences were encouraged for students, Pitman and Broomhall (2009) analyzed the statements of learning outcomes available on the websites of 38 Australian universities. The analysis revealed that communication, interpersonal skills, and problem-solving were most mentioned in the learning outcomes statements across the universities. The researchers also suggested differences in the selection of the intended softskills outcomes between groups of universities: Group of Eight (Go8), the Australian Technology Network (ATN), Innovative Research Universities Australia (IRU Australia), New Generation Universities (NGU), and the Unaligned Universities (UU). Such differences appeared to associate with the mission of each university. For example, the Go8 comprises Australia's oldest universities, which all have a strong liberal arts tradition; thus, $86 \%$ of the statements of this group have moral attributes compared with $50 \%, 67 \%, 56 \%$, and $63 \%$, respectively, in the other groups. Similarly, IRU Australia leads the other groups in terms of selecting "critical and analytical thinking" (100\%) because they are more focused on innovation and research. These findings indicate that the discrepancy in soft-skills selection across universities of the same education system is likely to depend on the surrounding contexts as well as the defined missions and purpose of an institution.

In 2009, Barrie, Hughes, and Smith (2009) explored progress in implementing graduate attributes across the Australian HE sector. They found that soft skills were conceptualized differently depending on how a university viewed itself in relation to the external world. If it appreciated students' performance in the workplace, soft skills were defined more closely to the notion of employability skills; if it valued the graduates' future and their quality of life, soft skills were more about preparing the students for the unknown future; and finally if its mission was linked to and strongly influenced by professional bodies or accreditation agencies, soft skills were more about compliance with the qualities and skills determined by these organizations. Thus, it is possible to conclude that the selection of soft skills is different across HEIs contingent to their defined mission and vision or the perceived purpose of $\mathrm{HE}$, which was raised by the B-HERT project a long time ago: "the contemporary focus on generic skills is really part of a bigger, as yet unresolved, debate about the purpose of university education and how to develop educated persons who are both employable and capable of contributing to civil society" (B-HERT, 2003, p. 6).

$\mathrm{HE}$ institutions are also observed to use different strategies and approaches for the implementation of soft skills. Universities can implement soft skills institutionwide (Fleming, Donovan, Beer, \& Clark, 2010) or program-wide (O’Neill, 2010; Willcoxson, Wynder, \& Laing, 2010). They can execute the implementation top- 
down, bottom-up, or a combination of both (Barrie, Hughes, Smith, \& Thomson, 2009; James, Lefoe, \& Hadi, 2004). Some institutions develop soft skills independently of disciplinary knowledge while some integrate them into the disciplinary curriculum (Al-Mahmood \& Gruba, 2007; Barrie, Hughes, \& Smith, 2009; Jääskelä, Nykänen, \& Tynjälä, 2018). Pedagogically, soft skills are developed via problem-based learning (Hendriana, Johanto, \& Sumarmo, 2018; Ibrahim, Al-Shahrani, Abdalla, Abubaker, \& Mohamed, 2018; Vogler et al., 2018); community-service learning (Eike, Myers, \& Sturges, 2018; Mak, Lau, \& Wong, 2017; Payton, Barnes, Buch, Rorrer, \& Zuo, 2015); online and distance learning (Brodie, 2011; Myers et al., 2014; Salleh, Tasir, \& Shukor, 2012); and work-integrated learning (Losekoot, Lasten, Lawson, \& Chen, 2018; Maelah, Aman, Mohamed, \& Ramli, 2012; Tran \& Nguyen, 2018). Finally, methods applied to soft-skills assessment also vary but mostly include capstone subject, (e)-portfolio, peer-assessment, and external assessment (in case of internship or work-placement) (Cranney et al., 2012; Hughes, Mylonas, \& Ballantyne, 2017; Keller, Parker, \& Chan, 2011; Palmer, Holt, Hall, \& Ferguson, 2011). In an attempt to explain such discrepancy in the strategies and approaches to soft-skills implementation, Al-Mahmood and Gruba (2007) and S. C. Barrie (2007) suggest that such differences can be attributed to the underlying assumption and attitudes towards soft skills held by each institution and its stakeholders.

Thus, it is indicated that soft skills can be addressed differently across HE institutions based on stakeholders' perception and attitudes towards soft skills as well as institutional missions and visions. Initiatives for developing soft skills for students at the institutional level will be elaborated on in the next chapter.

\section{Conclusion}

In short, soft skills can be understood differently by individuals of different roles or organizations of different functions. It can be used as a general term to refer to non-technical skills. These skills are elusive, discipline-relating, and transferable between contexts. They cluster and complement each other and require substantial time and practice to grow to a level where they can be used naturally. Soft skills have become an essential part of $\mathrm{HE}$ curricula and developing soft skills for students has become a priority in the operation of $\mathrm{HE}$ institutions. Despite differences in approaches, the implementation of soft skills is commonly driven by political, socioeconomic, and cultural factors as well as a country's educational values. Most of the literature related to soft-skills development for enhancing graduates' employability derives from Western-developed and English-speaking countries. There has been a lack of similar research in developing, non-Englishspeaking countries whose politics, socioeconomic status, cultural features, and educational values may be different. It is useful to investigate the implementation of soft skills in these countries to complement existing literature in building soft skills for employability in HE so that our understanding about this issue can be extended. 


\section{The surge in developing soft skills}

\section{References}

Al-Mahmood, R., \& Gruba, P. (2007). Approaches to the implementation of generic graduate attributes in Australian ICT undergraduate education. Computer Science Education, 17(3), 171-185.

Ang, L., D'Alessandro, S., \& Winzar, H. (2014). A visual-based approach to the mapping of generic skills: its application to a marketing degree. Higher Education Research \& Development, 33(2), 181-197.

Atlay, M. (2006). Skills development: Ten years of evolution from institutional specification to more student-centered approach. In P. Hager \& S. Holland (Eds.), Graduate attributes, learning and employability (pp. 169-186). Dordrecht, The Netherlands: Springer.

B-HERT (2003). Developing generic skills: Examples of best practice. B-HERT News. Retrieved from https://bit.ly/2GAJ9QL

Banks, J. A. (2007). Diversity and citizenship education: Global perspectives. San Francisco, CA: Jossey-Bass.

Barrie, S., Hughes, C., \& Smith, C. (2009). The national graduate attributes project: Integration and assessment of graduate attributes in curriculum. Sydney: Australian Learning and Teaching Council.

Barrie, S., Hughes, C., Smith, C., \& Thomson, K. (2009). The national graduate attributes project: Key issues to consider in the renewal of learning and teaching experiences to foster graduate attributes. Sydney: The University of Sydney.

Barrie, S. C. (2007). A conceptual framework for the teaching and learning of generic graduate attributes. Studies in Higher Education, 32(4), 439-458.

Bowden, J., Hart, G., King, B., Trigwell, K., \& Watts, O. (2000). Generic capabilities of ATN university graduates. Canberra: Australian Government Department of Education, Training and Youth Affairs.

Bowman, K. (2010). Background paper for the AQF Council on generic skills. Retrieved from www.voced.edu.au/content/ngv\%3A46853

Bredgaard, T., \& Madsen, P. K. (2018). Farewell flexicurity? Danish flexicurity and the crisis. Transfer: European Review of Labour and Research. doi: 10.1177/ 1024258918768613

Bridges, D. (1993). Transferable skills: A philosophical perspective. Studies in Higher Education, 18(1), 43-51.

Brodie, L. (2011). Delivering key graduate attributes via teams working in virtual space. International Journal of Emerging Technologies in Learning (iJET), 6(3), 5-11.

Chaisinthop, N. (2014). Volunteering, Dana, and the cultivation of 'good people'in Thailand. Anthropological Forum, 24(4), 396-411. doi: 10.1080/00664677.2014.965129

Chansomsak, S., \& Vale, B. (2008). The Buddhist approach to education: An alternative approach for sustainable education. Asia Pacific Journal of Education, 28(1), 35-50.

Cinque, M. (2016). "Lost in translation": Soft skills development in European countries. Tuning Journal for Higher Education, 3(2), 389-427. doi: 10.18543/tjhe-3(2)2016pp389-427

Coates, H., \& Richardson, S. (2012). An international assessment of bachelor degree graduates' learning outcomes. Higher Education Management and Policy, 23(3), 1-19.

Cranney, J., Kofod, M., Huon, G., Jensen, L., Levin, K., McAlpine, I., Scoufis, M., \& Whitaker, N. (2012). Portfolio tools: Learning and teaching strategies to facilitate development of graduate attributes. Paper presented at the Australian Conference on Science and Mathematics Education (formerly UniServe Science Conference). Retrieved from: http s://openjournals.library.sydney.edu.au/index.php/IISME/article/view/6431/7078 
Danish Government (2008). Qualifications framework for Danish higher education. Retrieved from https://bit.ly/2URzxtC.

Davis, B. D., \& Muir, C. (2004). Learning soft skills at work: An interview with Annalee Luhman. Business Communication Quarterly, 67(1), 95-101.

Dehkord, F. K., Samimi, M., Alivand, R., \& Sani, E. A. (2017). An examination and assessment of knowledge management maturity in Karaj municipality. Journal of Ecophysiology and Occupational Health, 17(1-2), 34-39.

Eike, R. J., Myers, B., \& Sturges, D. (2018). The impact of service-learning targeting apparel design majors: A qualitative analysis of learning growth. Family and Consumer Sciences Research Journal, 46(3), 267-281.

Fleming, J., Donovan, R., Beer, C., \& Clark, D. (2013). A whole of university approach to embedding graduate attributes: A reflection. In J. Willems, B. Tynan, \& R. James (Eds.), Global challenges and perspectives in blended and distance learning (pp. 246-257). Hershey, PA: IGI Global.

Gonczi, A. (2006). The OECD: Its role in the key competencies debate and in the promotion of lifelong learning. In P. Hager \& S. Holland (Eds.), Graduate attributes, learning and employability (pp. 105-124). Dordrecht: Springer.

González, J., \& Wagenaar, R. (2003). Tuning educational structures in Europe. Bilbao, Spain: University of Deusto.

Groh, M., Krishnan, N., McKenzie, D., \& Vishwanath, T. (2016). The impact of soft skills training on female youth employment: Evidence from a randomized experiment in Jordan. IZA Journal of Labor \& Development, 5(1). doi: 10.1186/s40175-016-0055-9

Hager, P., \& Holland, S. (2006). Graduate attributes, learning and employability (Vol. 6). Dordrecht, Netherlands: Springer Science \& Business Media.

Hardison, C. M., \& Vilamovska, A.-M. (2009). The collegiate learning assessment: Setting standards for performance at a college or university. Santa Monica, CA: Rand Corporation.

Heckman, J. J., \& Kautz, T. (2012). Hard evidence on soft skills. Labour Economics, 19(4), $451-464$.

Heckman, J. J., \& Rubinstein, Y. (2001). The importance of noncognitive skills: Lessons from the GED testing program. American Economic Review, 91(2), 145-149.

Hendriana, H., Johanto, T., \& Sumarmo, U. (2018). The role of problem-based learning to improve students' mathematical problem-solving ability and self-confidence. Journal on Mathematics Education, 9(2), 291-300.

Hind, D. W. (1994). Transferable personal skills (2nd edition). Tyne \& Wear, UK: Business Education Publishers.

Hughes, K., Mylonas, A., \& Ballantyne, R. (2017). Enhancing tourism graduates' soft skills: The importance of teaching reflective practice. In P. Benckendorff \& A. Zehrer (Eds.), Handbook of teaching and learning in tourism (pp. 95-106). Northampton, MA: Edward Elgar.

Ibrahim, M. E., Al-Shahrani, A. M., Abdalla, M. E., Abubaker, I. M., \& Mohamed, M. E. (2018). The effectiveness of problem-based learning in acquisition of knowledge, soft skills during basic and preclinical sciences: Medical students' points of view. Acta Informatica Medica, 26(2), 119-124.

Jääskelä, P., Nykänen, S., \& Tynjälä, P. (2018). Models for the development of generic skills in Finnish higher education. Journal of Further and Higher Education, 42(1), 130-142.

James, B., Lefoe, G. E., \& Hadi, M. N. (2004). Working 'through'graduate attributes: A bottom-up approach. Paper presented at the HERDSA International Conference, 4-7 July, Miri Sarawak, Milperra, New South Wales, Australia. 
Jones, A. (2010). Generic attributes in accounting: The significance of the disciplinary context. Accounting Education: An International Journal, 19(1-2), 5-21.

Keller, S., Parker, C. M., \& Chan, C. (2011). Employability skills: Student perceptions of an IS final year capstone subject. Innovation in Teaching and Learning in Information and Computer Sciences, 10(2), 4-15.

Kennedy, K. J., Fairbrother, G., \& Zhao, Z. (2013). Citizenship education in China: Preparing citizens for the "Chinese century". New York and London: Routledge.

Klindt, M. P., Baadsgaard, K., \& Jørgensen, H. (2017). Beyond flexicurity: The shift towards work-first and its implications for street-level work in the Danish employment system. In K. Hogsbro \& I. F. Shaw (Eds.), Social work and research in advanced welfare states (pp. 47-60). London and New York: Routledge.

Knight, P. (2007). Fostering and assessing 'wicked' competences. Retrieved from https://bit. $\mathrm{ly} / 2 \mathrm{E} 7 \mathrm{bFHq}$

Kyllonen, P. C. (2013). Soft skills for the workplace. Change: The Magazine of Higher Learning, 45(6), 16-23.

Laker, D. R., \& Powell, J. L. (2011). The differences between hard and soft skills and their relative impact on training transfer. Human Resource Development Quarterly, 22(1), 111-122.

Lawson, R., Taylor, T., Fallshaw, E., Summers, J., Kinash, S., French, E., \& AngusLeppan, T. (2013). Hunters and gatherers: Strategies for curriculum mapping and data collection for assuring learning. Retrieved from https://bit.ly/2DqAWgk

Litecky, C. R., Arnett, K. P., \& Prabhakar, B. (2004). The paradox of soft skills versus technical skills in IS hiring. Journal of Computer Information Systems, 45(1), 69-76.

Losekoot, E., Lasten, E., Lawson, A., \& Chen, B. (2018). The development of soft skills during internships: The hospitality student's voice. Research in Hospitality Management, $8(2), 155-159$.

Ma Rhea, Z. (2018). Buddhist pedagogy in teacher education: Cultivating wisdom by skillful means. Asia-Pacific Journal of Teacher Education, 46(2), 199-216.

Maelah, R., Aman, A., Mohamed, Z. M., \& Ramli, R. (2012). Enhancing soft skills of accounting undergraduates through industrial training. Procedia-Social and Behavioral Sciences, 59(Oct), 541-549.

Mak, B., Lau, C., \& Wong, A. (2017). Effects of experiential learning on students: An ecotourism service-learning course. Journal of Teaching in Travel \& Tourism, 17(2), 85-100.

Mayer, E. (1992). Employment-related key competencies: A proposal for consultation. Melbourne, Australia: Mayer Committee.

Mitchell, G. W., Skinner, L. B., \& White, B. J. (2010). Essential soft skills for success in the twenty-first century workforce as perceived by business educators. Delta Pi Epsilon Journal, 52(1), 43-53.

Myers, T., Blackman, A., Andersen, T., Hay, R., Lee, I., \& Gray, H. (2014). Cultivating ICT students' interpersonal soft skills in online learning environments using traditional active learning techniques. Journal of Learning Design, 7(3), 38-53.

O'Neill, G. (2010). A programme wide approach to assessment: A reflection on some curriculum mapping tools. Paper presented at the AISHE Conference, Dublin, Ireland. Retrieved from https://bit.ly/2Vhrl6W

OECD (2015). Skills for social progress: The power of social and emotional skills. Retrieved from https://bit.ly/2qn2PMP

Palmer, S., Holt, D., Hall, W., \& Ferguson, C. (2011). An evaluation of an online student portfolio for the development of engineering graduate attributes. Computer Applications in Engineering Education, 19(3), 447-456. 
Payton, J., Barnes, T., Buch, K., Rorrer, A., \& Zuo, H. (2015). The effects of integrating service learning into computer science: An inter-institutional longitudinal study. Computer Science Education, 25(3), 311-324.

Pimpa, N. (2011). Strategies for higher education reform in Thailand. In S. Marginson, S. Kaur, \& E. Sawi (Eds.), Higher Education in the Asia-Pacific (pp. 273-289). New York, NY: Springer.

Pitman, T., \& Broomhall, S. (2009). Australian universities, generic skills and lifelong learning. International Journal of Lifelong Education, 28(4), 439-458.

Quality Assurance Agency for Higher Education (2008). The framework for higher education qualifications in England, Wales and Northern Ireland. Quality Assurance Agency for Higher Education. Retrieved from: www.ncl.ac.uk/ltds/assets/documents/qsh-p rogapp-fheqsummary.pdf

Robles, M. M. (2012). Executive perceptions of the top 10 soft skills needed in today's workplace. Business Communication Quarterly, 75(4), 453-465.

Salleh, S. M., Tasir, Z., \& Shukor, N. A. (2012). Web-based simulation learning framework to enhance students' critical thinking skills. Procedia-Social and Behavioral Sciences, 64 (Nov), 372-381.

Shakir, R. (2009). Soft skills at the Malaysian institutes of higher learning. Asia Pacific Education Review, 10(3), 309-315.

Sharma, Y. (2015). OECD to launch university outcomes benchmark system. University World News, 22 Oct. Retrieved from www.universityworldnews.com/article.php?story= 20151015142742541

Tertiary Education Quality and Standards Agency (2013). Australian qualifications framework. The Australian Qualifications Framework Council. Retrieved from: https://bit.ly/ 2UxTUHm

Thai Government (2006). National qualifications framework for higher education in Thailand. Retrieved from: https://bit.ly/2DsbFSX

The Quality Assurance Agency for Higher Education (2014). The frameworks for higher education qualifications of UK degree-awarding bodies. Retrieved from: www.qaa.ac.uk/ docs/qaa/quality-code/qualifications-frameworks.pdf

Tran, L. H. N., \& Nguyen, T. M. D. (2018). Internship-related learning outcomes and their influential factors: The case of Vietnamese tourism and hospitality students. $E d u$ cation + Training, 60(1), 69-81.

Treleaven, L., \& Voola, R. (2008). Integrating the development of graduate attributes through constructive alignment. Journal of Marketing Education, 30(2), 160-173.

Tremblay, K., Lalancette, D., \& Roseveare, D. (2012). Assessment of higher education learning outcomes. OECD. Retrieved from: https://bit.ly/2IRTRnB

Tuning Educational Structures in Europe (2019). Tuning methodology. Retrieved from: www.unideusto.org/tuningeu/tuning-methodology.html

Vogler, J. S., Thompson, P., Davis, D. W., Mayfield, B. E., Finley, P. M., \& Yasseri, D. (2018). The hard work of soft skills: Augmenting the project-based learning experience with interdisciplinary teamwork. Instructional Science, 46(3), 457-488.

Weber, M. R., Finley, D. A., Crawford, A., \& Rivera Jr, D. (2009). An exploratory study identifying soft skill competencies in entry-level managers. Tourism and Hospitality Research, 9(4), 353-361.

Willcoxson, L., Wynder, M., \& Laing, G. K. (2010). A whole-of-program approach to the development of generic and professional skills in a university accounting program. Accounting Education: An International Journal, 19(1-2), 65-91. 


\section{Notes}

\section{Chapter 3}

1 In Vietnam, HE institutions are not allowed to enroll students as they wish; instead, they follow the quota annually allotted by MOET, as at the time this book is written.

\section{Chapter 4}

1 Disciplinary teachers are teachers who teach specialized subjects in the Business Administration program.

2 Skills teachers are teachers who teach subjects that train students in certain soft skills, such as communication skills, computer skills, and English skills.

3 The Youth Union and associates is a socio-political organization established by Ho Chi Minh under the Communist Party. It is installed in each school and university in Vietnam and is in charge of political education and leading social-engagement activities.

\section{Chapter 5}

$1 \mathrm{l}$ credit is equivalent to 15 face-to-face teaching sessions of 45 minutes for theoretical subjects.

\section{Chapter 6}

1 Students are classified as external stakeholders because they only stay with the university for a limited time and are not involved in the internal affairs of the university, except those related to their learning.

\section{Chapter 7}

1 The YUA are socio-political organisations under the Communist Party of Vietnam that are installed in each school and university, primarily in charge of political education and leading social engagement activities. 
2 At the time of research, the MOET regulated that an undergraduate program should be organised within 120-140 credits, where a credit is equivalent to 15 sessions of $45-50$ minute face-to-face teaching-learning.

\section{Chapter 8}

1 KSAOs refer to knowledge, skills, abilities, and other characteristics. 


\section{References}

Al-Mahmood, R., \& Gruba, P. (2007). Approaches to the implementation of generic graduate attributes in Australian ICT undergraduate education. Computer Science Education, 17(3), 171-185.

Anwar, S., \& Nguyen, L. P. (2014). Is foreign direct investment productive? A case study of the regions of Vietnam. Journal of Business Research, 67(7), 1376-1387.

Bajada, C., \& Trayler, R. (2013). Interdisciplinary business education: Curriculum through collaboration. Education + Training, 55(4/5), 385-402.

Barrie, S., Hughes, C., Smith, C., \& Thomson, K. (2009). The national graduate attributes project: Key issues to consider in the renewal of learning and teaching experiences to foster graduate attributes. Sydney: The University of Sydney.

Bodewig, C., \& Badiani-Magnusson, R. (2014). Skilling up Vietnam: Preparing the workforce for a modern market economy. Washington, DC: World Bank Publications.

Bowman, K. (2010). Background paper for the AQF Council on generic skills. Retrieved from: www.voced.edu.au/content/ngv\%3A46853

Brunner, B. R., Zarkin, K., \& Yates, B. L. (2018). What do employers want? What should faculty teach? A content analysis of entry-level employment ads in public relations. Retrieved from https://bit.ly/2BOJj4x

Clarke, M. (2017). Rethinking graduate employability: The role of capital, individual attributes and context. Studies in Higher Education, 43(11), 1923-1937.

de la Harpe, B., \& David, C. (2012). Major influences on the teaching and assessment of graduate attributes. Higher Education Research \& Development, 31(4), 493-510.

Dehkord, F. K., Samimi, M., Alivand, R., \& Sani, E. A. (2017). An examination and assessment of knowledge management maturity in Karaj municipality. Journal of Ecophysiology and Occupational Health, 17(1-2), 34-39.

Eisner, S. (2010). Grave new world? Workplace skills for today's college graduates. American Journal of Business Education, 3(9), 27-50.

Fugate, M., Kinicki, A. J., \& Ashforth, B. E. (2004). Employability: A psycho-social construct, its dimensions, and applications. Journal of Vocational Behavior, 65(1), 14-38.

Gayani Fernando, N., Amaratunga, D., \& Haigh, R. (2014). The career advancement of the professional women in the UK construction industry: The career success factors. Journal of Engineering, Design and Technology, 12(1), 53-70.

Gonczi, A. (2006). The OECD: Its role in the key competencies debate and in the promotion of lifelong learning. In P. Hager \& S. Holland (Eds.), Graduate attributes, learning and employability (pp. 105-124). Dordrecht: Springer. 
Groh, M., Krishnan, N., McKenzie, D., \& Vishwanath, T. (2016). The impact of soft skills training on female youth employment: Evidence from a randomized experiment in Jordan. IZA Journal of Labor \& Development, 5(1). doi: 10.1186/s40175-016-0055-9

Harman, G., Hayden, M., \& Nghi, P. T. (2010). Higher education in Vietnam: Reform, challenges and priorities. New York: Springer.

Ivanaj, V., \& Ivanaj, S. (2010). The contribution of interdisciplinary skills to the sustainability of business: When artists, engineers, and managers work together to serve enterprises. In J. A. F. Stoner \& C. Wankel (Eds.) Global sustainability as a business imperative (pp. 91-109). New York: Palgrave Macmillan.

Jackson, D. (2018). Developing graduate career readiness in Australia: Shifting from extracurricular internships to work-integrated learning. International Journal of Work-Integrated Learning, 19(1), 23-35.

Jones, A. (2009). Generic attributes as espoused theory: The importance of context. Higher Education, 58(2), 175-191.

Jurje, F., \& Lavenex, S. (2015). ASEAN Economic Community: What model for labour mobility? Working paper 2. NCCR-Swiss National Centre of Competence in Research. Retrieved from: www.wti.org/media/filer_public/24/f2/24f2c553-c4cc-4cc2-b670-6144e

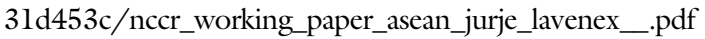

Lehndorff, S. (2016). Internal devaluation and employment trends in Germany. In M. Myant, S. Theodoropoulou, \& A. Piasna (Eds.), Unemployment, internal devaluation and labour market deregulation in Europe (pp. 169-196). Brussels: European Trade Union Institute (ETUI).

Lewchuk, W. (2017). Precarious jobs: Where are they, and how do they affect well-being? The Economic and Labour Relations Review, 28(3), 402-419.

Lindorff, M. (2011). Skills gaps in Australian firms. Journal of Vocational Education and Training, 63(2), 247-259.

Litecky, C. R., Arnett, K. P., \& Prabhakar, B. (2004). The paradox of soft skills versus technical skills in IS hiring. Journal of Computer Information Systems, 45(1), 69-76.

Maciejewska, M., Mrozowicki, A., \& Piasna, A. (2016). The silent and crawling crisis: International competition, labour market reforms and precarious jobs in Poland. In M. Myant, S. Theodoropoulou, \& A. Piasna (Eds.), Unemployment, internal devaluation and labour market deregulation in Europe (pp. 229-254). Brussels: European Trade Union Institute (ETUI).

Maria, C. (2016). "Lost in translation": Soft skills development in European countries. Tuning Journal for Higher Education, 3(2), 389-427. doi: 10.18543/tjhe-3(2)2016pp389-427

McMurray, S., Dutton, M., McQuaid, R., \& Richard, A. (2016). Employer demands from business graduates. Education + Training, 58(1), 112-132.

McQuaid, R. W., \& Lindsay, C. (2005). The concept of employability. Urban Studies, 42(2), $197-219$.

MOET (2010). Công văn 2916/ BGDĐT-GDĐH huớng dẫn xây dưng và công bố chuẩn đầu ra ngành đào tạo. Retrieved from http://thuvienphapluat.vn/cong-van/Giao-duc/ Cong-van-2196-BGDDT-GDDH-cong-bo-chuan-dau-ra-nganh-dao-tao-104676.aspx

MOET (2013). Công văn 2435/BGDĐT-GDĐH về việc rà soát chnẩn đầu ra và biên soạn giáo trinh. Retrieved from http://thuvienphapluat.vn/cong-van/Giao-duc/Cong-va n-2435-BGDDT-GDDH-ra-soat-chuan-dau-ra-va-bien-soan-giao-trinh-182111.aspx

Mok, K. H., \& Jiang, J. (2018). Massification of higher education and challenges for graduate employment and social mobility: East Asian experiences and sociological reflections. International Journal of Educational Development, 63(Nov), 44-51. 
Nickson, D., Warhurst, C., Commander, J., Hurrell, S. A., \& Cullen, A. M. (2012). Soft skills and employability: Evidence from UK retail. Economic and Industrial Democracy, $33(1), 65-84$.

Oliver, B. (2015). Redefining graduate employability and work-integrated learning: Proposals for effective higher education in disrupted economies. Journal of Teaching and Learning for Graduate Employability, 6(1), 56-65.

Osman, K. (2011). The inculcation of generic skills through service learning experience among science student teachers. Procedia-Social and Behavioral Sciences, 18, 148-153.

Rossi, B. (2017). Technology is ready to define the future of the workplace. Information Age. 18 April. Retrieved from www.information-age.com/technology-ready-define-fu ture-workplace-123465776/

Schilling, M. A. (2010). Strategic management of technological innovation. New York: Tata McGraw-Hill Education.

Stevens, M., \& Norman, R. (2016). Industry expectations of soft skills in IT graduates: A regional survey. Paper presented at the Proceedings of the Australasian Computer Science Week Multiconference, February 2-5, Canberra, Australia.

Suci, S. C., Asmara, A., \& Mulatsih, S. (2016). The impact of globalization on economic growth in ASEAN. Bisnis \& Birokrasi Journal, 22(2), 79-87.

Susskind, R. E., \& Susskind, D. (2015). The future of the professions: How technology will transform the work of human experts. Oxford: Oxford University Press.

Tertiary Education Quality and Standards Agency (2013). Australian qualifications framework. Canberra: The Australian Qualifications Framework Council.

The Statistics Portal (2018). Unemployment rate in member states of the European Union in June 2018. Retrieved from www.statista.com/statistics/268830/unemployment-ra te-in-eu-countries/

Tomlinson, M. (2017). Forms of graduate capital and their relationship to graduate employability. Education + Training, 59(4), 338-352.

Tran, A. N., \& Nørlund, I. (2015). Globalization, industrialization, and labor markets in Vietnam. Journal of the Asia Pacific Economy, 20(1), 143-163.

Tran, L. H. N. (2017a). Developing employability skills via extra-curricular activities in Vietnamese universities: Student engagement and inhibitors of their engagement. Journal of Education and Work, 30(8), 854-867.

Tran, L. H. N. (2017b). What hinders teachers from translating their beliefs into teaching behaviors: The case of teaching generic skills in Vietnamese universities. Teaching and Teacher Education, 64(May), 105-114.

Tran, L. H. N. (2018). Game of blames: Higher education stakeholders' perceptions of causes of Vietnamese graduates' skills gap. International Journal of Educational Development, 62(Sep), 302-312.

Tran, T. T. (2013). Limitation on the development of skills in higher education in Vietnam. Higher Education, 65(5), 631-644.

Tran, Q. T., \& Swierczek, F. W. (2009). Skills development in higher education in Vietnam. Asia Pacific Business Review, 15(4), 565-586.

Trinh, L. Q., \& Doan, H. T. T. (2018). Internationalization and the growth of Vietnamese micro, small, and medium sized enterprises: Evidence from panel quantile regressions. Journal of Asian Economics, 55(April), 71-83.

Truong, T. T. H., Laura, R. S., \& Shaw, K. (2018). The importance of developing soft skill sets for the employability of business graduates in Vietnam: A field study on selected business employers. Journal of Education and Culture Studies, 2(1), 32-45. 
Truong, Q. D., \& Metzger, C. (2007). Quality of business graduates in Vietnamese institutions: Multiple perspectives. Journal of Management Development, 26(7), 629-643.

Vedder, R., Denhart, C., \& Robe, J. (2013). Why are recent college graduates underemployed? University enrollments and labour-market realities. Washington, DC: Center for College Affordability and Productivity.

Yang, L. (2018). Higher education expansion and post-college unemployment: Understanding the roles of fields of study in China. International Journal of Educational Development, 62(Sep), 62-74.

Yorke, M. (2006). Employability in higher education: What it is, what it is not. Retrieved from https://bit.ly/22VzZS0

Al-Mahmood, R., \& Gruba, P. (2007). Approaches to the implementation of generic graduate attributes in Australian ICT undergraduate education. Computer Science Education, 17(3), 171-185.

Ang, L., D’Alessandro, S., \& Winzar, H. (2014). A visual-based approach to the mapping of generic skills: its application to a marketing degree. Higher Education Research \& Development, 33(2), 181-197.

Atlay, M. (2006). Skills development: Ten years of evolution from institutional specification to more student-centered approach. In P. Hager \& S. Holland (Eds.), Graduate attributes, learning and employability (pp. 169-186). Dordrecht, The Netherlands: Springer.

B-HERT (2003). Developing generic skills: Examples of best practice. B-HERT News. Retrieved from https://bit.ly/2GAJ9QL

Banks, J. A. (2007). Diversity and citizenship education: Global perspectives. San Francisco, CA: Jossey-Bass.

Barrie, S., Hughes, C., \& Smith, C. (2009). The national graduate attributes project: Integration and assessment of graduate attributes in curriculum. Sydney: Australian Learning and Teaching Council.

Barrie, S., Hughes, C., Smith, C., \& Thomson, K. (2009). The national graduate attributes project: Key issues to consider in the renewal of learning and teaching experiences to foster graduate attributes. Sydney: The University of Sydney.

Barrie, S. C. (2007). A conceptual framework for the teaching and learning of generic graduate attributes. Studies in Higher Education, 32(4), 439-458.

Bowden, J., Hart, G., King, B., Trigwell, K., \& Watts, O. (2000). Generic capabilities of ATN university graduates. Canberra: Australian Government Department of Education, Training and Youth Affairs.

Bowman, K. (2010). Background paper for the AQF Council on generic skills. Retrieved from www.voced.edu.au/content/ngv\%3A46853

Bredgaard, T., \& Madsen, P. K. (2018). Farewell flexicurity? Danish flexicurity and the crisis. Transfer: European Review of Labour and Research. doi: 10.1177/ 1024258918768613

Bridges, D. (1993). Transferable skills: A philosophical perspective. Studies in Higher Education, 18(1), 43-51.

Brodie, L. (2011). Delivering key graduate attributes via teams working in virtual space. International Journal of Emerging Technologies in Learning (iJET), 6(3), 5-11.

Chaisinthop, N. (2014). Volunteering, Dana, and the cultivation of 'good people'in Thailand. Anthropological Forum, 24(4), 396-411. doi: 10.1080/00664677.2014.965129

Chansomsak, S., \& Vale, B. (2008). The Buddhist approach to education: An alternative approach for sustainable education. Asia Pacific Journal of Education, 28(1), 35-50. 
Cinque, M. (2016). "Lost in translation": Soft skills development in European countries. Tuning Journal for Higher Education, 3(2), 389-427. doi: 10.18543/tjhe-3(2)2016pp389-427

Coates, H., \& Richardson, S. (2012). An international assessment of bachelor degree graduates' learning outcomes. Higher Education Management and Policy, 23(3), 1-19.

Cranney, J., Kofod, M., Huon, G., Jensen, L., Levin, K., McAlpine, I., Scoufis, M., \& Whitaker, N. (2012). Portfolio tools: Learning and teaching strategies to facilitate development of graduate attributes. Paper presented at the Australian Conference on Science and Mathematics Education (formerly UniServe Science Conference). Retrieved from: http s://openjournals.library.sydney.edu.au/index.php/IISME/article/view/6431/7078

Danish Government (2008). Qualifications framework for Danish higher education. Retrieved from https://bit.ly/2URzxtC.

Davis, B. D., \& Muir, C. (2004). Learning soft skills at work: An interview with Annalee Luhman. Business Communication Quarterly, 67(1), 95-101.

Dehkord, F. K., Samimi, M., Alivand, R., \& Sani, E. A. (2017). An examination and assessment of knowledge management maturity in Karaj municipality. Journal of Ecophysiology and Occupational Health, 17(1-2), 34-39.

Eike, R. J., Myers, B., \& Sturges, D. (2018). The impact of service-learning targeting apparel design majors: A qualitative analysis of learning growth. Family and Consumer Sciences Research Journal, 46(3), 267-281.

Fleming, J., Donovan, R., Beer, C., \& Clark, D. (2013). A whole of university approach to embedding graduate attributes: A reflection. In J. Willems, B. Tynan, \& R. James (Eds.), Global challenges and perspectives in blended and distance learning (pp. 246-257). Hershey, PA: IGI Global.

Gonczi, A. (2006). The OECD: Its role in the key competencies debate and in the promotion of lifelong learning. In P. Hager \& S. Holland (Eds.), Graduate attributes, learning and employability (pp. 105-124). Dordrecht: Springer.

González, J., \& Wagenaar, R. (2003). Tuning educational structures in Europe. Bilbao, Spain: University of Deusto.

Groh, M., Krishnan, N., McKenzie, D., \& Vishwanath, T. (2016). The impact of soft skills training on female youth employment: Evidence from a randomized experiment in Jordan. IZA Journal of Labor \& Development, 5(1). doi: 10.1186/s40175-016-0055-9

Hager, P., \& Holland, S. (2006). Graduate attributes, learning and employability (Vol. 6). Dordrecht, Netherlands: Springer Science \& Business Media.

Hardison, C. M., \& Vilamovska, A.-M. (2009). The collegiate learning assessment: Setting standards for performance at a college or university. Santa Monica, CA: Rand Corporation.

Heckman, J. J., \& Kautz, T. (2012). Hard evidence on soft skills. Labour Economics, 19(4), 451-464.

Heckman, J. J., \& Rubinstein, Y. (2001). The importance of noncognitive skills: Lessons from the GED testing program. American Economic Review, 91(2), 145-149.

Hendriana, H., Johanto, T., \& Sumarmo, U. (2018). The role of problem-based learning to improve students' mathematical problem-solving ability and self-confidence. Journal on Mathematics Education, 9(2), 291-300.

Hind, D. W. (1994). Transferable personal skills (2nd edition). Tyne \& Wear, UK: Business Education Publishers.

Hughes, K., Mylonas, A., \& Ballantyne, R. (2017). Enhancing tourism graduates' soft skills: The importance of teaching reflective practice. In P. Benckendorff \& A. Zehrer 
(Eds.), Handbook of teaching and learning in tourism (pp. 95-106). Northampton, MA: Edward Elgar.

Ibrahim, M. E., Al-Shahrani, A. M., Abdalla, M. E., Abubaker, I. M., \& Mohamed, M. E. (2018). The effectiveness of problem-based learning in acquisition of knowledge, soft skills during basic and preclinical sciences: Medical students' points of view. Acta Informatica Medica, 26(2), 119-124.

Jääskelä, P., Nykänen, S., \& Tynjälä, P. (2018). Models for the development of generic skills in Finnish higher education. Journal of Further and Higher Education, 42(1), 130-142.

James, B., Lefoe, G. E., \& Hadi, M. N. (2004). Working 'through'graduate attributes: A bottom-up approach. Paper presented at the HERDSA International Conference, 4-7 July, Miri Sarawak, Milperra, New South Wales, Australia.

Jones, A. (2010). Generic attributes in accounting: The significance of the disciplinary context. Accounting Education: An International Journal, 19(1-2), 5-21.

Keller, S., Parker, C. M., \& Chan, C. (2011). Employability skills: Student perceptions of an IS final year capstone subject. Innovation in Teaching and Learning in Information and Computer Sciences, 10(2), 4-15.

Kennedy, K. J., Fairbrother, G., \& Zhao, Z. (2013). Citizenship education in China: Preparing citizens for the "Chinese century". New York and London: Routledge.

Klindt, M. P., Baadsgaard, K., \& Jørgensen, H. (2017). Beyond flexicurity: The shift towards work-first and its implications for street-level work in the Danish employment system. In K. Hogsbro \& I. F. Shaw (Eds.), Social work and research in advanced welfare states (pp. 47-60). London and New York: Routledge.

Knight, P. (2007). Fostering and assessing 'wicked' competences. Retrieved from https://bit. ly $/ 2 \mathrm{E} 7 \mathrm{bFHq}$

Kyllonen, P. C. (2013). Soft skills for the workplace. Change: The Magazine of Higher Learning, 45(6), 16-23.

Laker, D. R., \& Powell, J. L. (2011). The differences between hard and soft skills and their relative impact on training transfer. Human Resource Development Quarterly, 22(1), 111-122.

Lawson, R., Taylor, T., Fallshaw, E., Summers, J., Kinash, S., French, E., \& AngusLeppan, T. (2013). Hunters and gatherers: Strategies for curriculum mapping and data collection for assuring learning. Retrieved from https://bit.ly/2DqAWgk

Litecky, C. R., Arnett, K. P., \& Prabhakar, B. (2004). The paradox of soft skills versus technical skills in IS hiring. Journal of Computer Information Systems, 45(1), 69-76.

Losekoot, E., Lasten, E., Lawson, A., \& Chen, B. (2018). The development of soft skills during internships: The hospitality student's voice. Research in Hospitality Management, $8(2), 155-159$.

Ma Rhea, Z. (2018). Buddhist pedagogy in teacher education: Cultivating wisdom by skillful means. Asia-Pacific Journal of Teacher Education, 46(2), 199-216.

Maelah, R., Aman, A., Mohamed, Z. M., \& Ramli, R. (2012). Enhancing soft skills of accounting undergraduates through industrial training. Procedia-Social and Behavioral Sciences, 59(Oct), 541-549.

Mak, B., Lau, C., \& Wong, A. (2017). Effects of experiential learning on students: An ecotourism service-learning course. Journal of Teaching in Travel \& Tourism, 17(2), 85-100.

Mayer, E. (1992). Employment-related key competencies: A proposal for consultation. Melbourne, Australia: Mayer Committee.

Mitchell, G. W., Skinner, L. B., \& White, B. J. (2010). Essential soft skills for success in the twenty-first century workforce as perceived by business educators. Delta Pi Epsilon Journal, 52(1), 43-53. 
Myers, T., Blackman, A., Andersen, T., Hay, R., Lee, I., \& Gray, H. (2014). Cultivating ICT students' interpersonal soft skills in online learning environments using traditional active learning techniques. Journal of Learning Design, 7(3), 38-53.

O'Neill, G. (2010). A programme wide approach to assessment: A reflection on some curriculum mapping tools. Paper presented at the AISHE Conference, Dublin, Ireland. Retrieved from https://bit.ly/2Vhrl6W

OECD (2015). Skills for social progress: The power of social and emotional skills. Retrieved from https://bit.ly/2qn2PMP

Palmer, S., Holt, D., Hall, W., \& Ferguson, C. (2011). An evaluation of an online student portfolio for the development of engineering graduate attributes. Computer Applications in Engineering Education, 19(3), 447-456.

Payton, J., Barnes, T., Buch, K., Rorrer, A., \& Zuo, H. (2015). The effects of integrating service learning into computer science: An inter-institutional longitudinal study. Computer Science Education, 25(3), 311-324.

Pimpa, N. (2011). Strategies for higher education reform in Thailand. In S. Marginson, S. Kaur, \& E. Sawi (Eds.), Higher Education in the Asia-Pacific (pp. 273-289). New York, NY: Springer.

Pitman, T., \& Broomhall, S. (2009). Australian universities, generic skills and lifelong learning. International Journal of Lifelong Education, 28(4), 439-458.

Quality Assurance Agency for Higher Education (2008). The framework for higher education qualifications in England, Wales and Northern Ireland. Quality Assurance Agency for Higher Education. Retrieved from: www.ncl.ac.uk/ltds/assets/documents/qsh-p rogapp-fheqsummary.pdf

Robles, M. M. (2012). Executive perceptions of the top 10 soft skills needed in today's workplace. Business Communication Quarterly, 75(4), 453-465.

Salleh, S. M., Tasir, Z., \& Shukor, N. A. (2012). Web-based simulation learning framework to enhance students' critical thinking skills. Procedia-Social and Behavioral Sciences, 64 (Nov), 372-381.

Shakir, R. (2009). Soft skills at the Malaysian institutes of higher learning. Asia Pacific Education Review, 10(3), 309-315.

Sharma, Y. (2015). OECD to launch university outcomes benchmark system. University World News, 22 Oct. Retrieved from www.universityworldnews.com/article.php?story= 20151015142742541

Tertiary Education Quality and Standards Agency (2013). Australian qualifications framework. The Australian Qualifications Framework Council. Retrieved from: https://bit.ly/ 2UxTUHm

Thai Government (2006). National qualifications framework for higher education in Thailand. Retrieved from: https://bit.ly/2DsbFSX

The Quality Assurance Agency for Higher Education (2014). The frameworks for higher education qualifications of UK degree-awarding bodies. Retrieved from: www.qaa.ac.uk/ docs/qaa/quality-code/qualifications-frameworks.pdf

Tran, L. H. N., \& Nguyen, T. M. D. (2018). Internship-related learning outcomes and their influential factors: The case of Vietnamese tourism and hospitality students. $E d u$ cation + Training, 60(1), 69-81.

Treleaven, L., \& Voola, R. (2008). Integrating the development of graduate attributes through constructive alignment. Journal of Marketing Education, 30(2), 160-173.

Tremblay, K., Lalancette, D., \& Roseveare, D. (2012). Assessment of higher education learning outcomes. OECD. Retrieved from: https://bit.ly/2IRTRnB 
Tuning Educational Structures in Europe (2019). Tuning methodology. Retrieved from: www.unideusto.org/tuningeu/tuning-methodology.html

Vogler, J. S., Thompson, P., Davis, D. W., Mayfield, B. E., Finley, P. M., \& Yasseri, D. (2018). The hard work of soft skills: Augmenting the project-based learning experience with interdisciplinary teamwork. Instructional Science, 46(3), 457-488.

Weber, M. R., Finley, D. A., Crawford, A., \& Rivera Jr, D. (2009). An exploratory study identifying soft skill competencies in entry-level managers. Tourism and Hospitality Research, 9(4), 353-361.

Willcoxson, L., Wynder, M., \& Laing, G. K. (2010). A whole-of-program approach to the development of generic and professional skills in a university accounting program. Accounting Education: An International Journal, 19(1-2), 65-91.

Al-Mahmood, R., \& Gruba, P. (2007). Approaches to the implementation of generic graduate attributes in Australian ICT undergraduate education. Computer Science Education, 17(3), 171-185.

Ang, L., D'Alessandro, S., \& Winzar, H. (2014). A visual-based approach to the mapping of generic skills: Its application to a Marketing degree. Higher Education Research \& Development, 33(2), 181-197.

B-HERT (2003). Developing generic skills: Examples of best practice. B-HERT News. Retrieved from https://bit.ly/2GAJ9QL

Barrie, S., Hughes, C., Smith, C., \& Thomson, K. (2009). The national graduate attributes project: Key issues to consider in the renewal of learning and teaching experiences to foster graduate attributes. Sydney: The University of Sydney.

Barrie, S. C. (2006). Understanding what we mean by the generic attributes of graduates. Higher Education, 51(2), 215-241.

Barrie, S. C. (2007). A conceptual framework for the teaching and learning of generic graduate attributes. Studies in Higher Education, 32(4), 439-458.

Bredgaard, T., \& Madsen, P. K. (2018). Farewell flexicurity? Danish flexicurity and the crisis. Transfer: European Review of Labour and Research. doi: 10.1177/ 1024258918768613

Brodie, L. (2011). Delivering key graduate attributes via teams working in virtual space. International Journal of Emerging Technologies in Learning (iJET), 6(3), 5-11.

Cacciolatti, L., Lee, S. H., \& Molinero, C. M. (2017). Clashing institutional interests in skills between government and industry: An analysis of demand for technical and soft skills of graduates in the UK. Technological Forecasting and Social Change, 119(Jun), 139-153.

Callaghan, R., \& McManus, J. (2010). Building the perfect graduate: What news employers want in new hires. Asia Pacific Media Educator, 20, 9-21.

Carrivick, J. L. (2011). Exploring the value of professional body accreditation for masters programmes. Journal of Geography in Higher Education, 35(4), 479-497.

Chaisinthop, N. (2014). Volunteering, Dana, and the cultivation of 'good people'in Thailand. Anthropological Forum, 24(4), 396-411. doi: 10.1080/00664677.2014.965129

Chan, C. K. Y., \& Fong, E. T. Y. (2018). Disciplinary differences and implications for the development of generic skills: A study of engineering and business students' perceptions of generic skills. European Journal of Engineering Education, 43(6), 927-949. Retrieved from https://bit.ly/2Uy7JFE

Chanock, K., Clerehan, R., Moore, T., \& Prince, A. (2004). Shaping university teaching towards measurement for accountability: Problems of the graduate skills assessment test. Australian Universities' Review, 47(1), 22-29. 
Cranney, J., Kofod, M., Huon, G., Jensen, L., Levin, K., McAlpine, I., Scoufis, M., \&Whitaker, N. (2012). Portfolio tools: learning and teaching strategies to facilitate development of graduate attributes. Retrieved from https://bit.ly/2KSckTE

Danish Government (2008). Qualifications framework for Danish higher education. Retrieved from https://bit.ly/2URzxtC

de la Harpe, B., \& David, C. (2012). Major influences on the teaching and assessment of graduate attributes. Higher Education Research \& Development, 31(4), 493-510.

de la Harpe, B., \& Radloff, A. (2008). Developing graduate attributes for lifelong learning: How far have we got? Paper presented at the 5th International Lifelong Learning Conference, 16-19 June, Queensland, Australia.

El Hassan, K. (2013). Quality assurance in higher education in 20 MENA economies. Higher Education Management and Policy, 24(2), 73-84.

Falk, J. H., Ballantyne, R., Packer, J., \& Benckendorff, P. (2012). Travel and learning: A neglected tourism research area. Annals of Tourism Research, 39(2), 908-927.

Fallows, S., \& Steven, C. (2000). Integrating key skills in higher education: employability, transferable skills and learning for life. London: Kogan Page.

Fleming, J., Donovan, R., Beer, C., \& Clark, D. (2013). A whole of university approach to embedding graduate attributes: A reflection. In J. Willems, B. Tynan, \& R. James (Eds.), Global challenges and perspectives in blended and distance learning (pp. 246-257). Hershey, PA: IGI Global.

Frank, B., Strong, D., Sellens, R., \& Clapham, L. (2013). Progress with the professional spine: A four-year engineering design and practice sequence. Australasian Journal of Engineering Education, 19(1), 63-74.

Gomes, V. G., Spandagou, I., \& Ahmadi, M. (2008). Peer assessment in imparting graduate attributes. Retrieved from https://bit.ly/2ICscHU

Gonczi, A. (2006). The OECD: Its role in the key competencies debate and in the promotion of lifelong learning. In P. Hager \& S. Holland (Eds.), Graduate attributes, learning and employability (pp. 105-124). Dordrecht, The Netherlands: Springer.

Grant-Smith, D., \& McDonald, P. (2018). Planning to work for free: Building the graduate employability of planners through unpaid work. Journal of Youth Studies, 21(2), 161-177.

Hager, P., \& Holland, S. (2006). Graduate attributes, learning and employability (Vol. 6). Dordrecht, Netherlands: Springer Science \& Business Media.

Hayes, J. (2018). The theory and practice of change management (5th edn). London: Palgrave MacMillan.

Heyman, J. E., \& Sailors, J. J. (2011). Peer assessment of class participation: Applying peer nomination to overcome rating inflation. Assessment \& Evaluation in Higher Education, 36(5), 605-618.

Holmes, D. W., Sheehan, M., Birks, M., \& Smithson, J. (2018). Development of a competency mapping tool for undergraduate professional degree programmes, using mechanical engineering as a case study. European Journal of Engineering Education, 43(1), 126-143.

Hughes, C., \& Barrie, S. (2010). Influences on the assessment of graduate attributes in higher education. Assessment \& Evaluation in Higher Education, 35(3), 325-334.

Jackson, D. (2014). Self-assessment of employability skill outcomes among undergraduates and alignment with academic ratings. Assessment \& Evaluation in Higher Education, 39(1), 53-72.

Jackson, D. (2018). Developing graduate career readiness in Australia: Shifting from extracurricular internships to work-integrated learning. International Journal of Work-Integrated Learning, 19(1), 23-35. 
James, R., Krause, K.-L., \& Jennings, C. (2009). The first year experience in Australian universities: Findings from 1994 to 2009. Retrieved from https://bit.ly/2KWCy7E

Jollands, M., Jolly, L., \& Molyneaux, T. (2012). Project-based learning as a contributing factor to graduates' work readiness. European Journal of Engineering Education, 37(2), $143-154$.

Jones, A. (2009). Generic attributes as espoused theory: The importance of context. Higher Education, 58(2), 175-191.

Jones, N., Torezani, S., \& Luca, J. (2012). A peer-to-peer support model for developing graduate students' career and employability skills. Intercultural Education, 23(1), 51-62.

Kao, G. Y. M. (2013). Enhancing the quality of peer review by reducing student "free riding": Peer assessment with positive interdependence. British Journal of Educational Technology, 44(1), 112-124.

Keller, S., Parker, C. M., \& Chan, C. (2011). Employability skills: Student perceptions of an IS final year capstone subject. Innovation in Teaching and Learning in Information and Computer Sciences, 10(2), 4-15.

Kennedy, K. J., Fairbrother, G., \& Zhao, Z. (2013). Citizenship education in China: Preparing citizens for the "Chinese century". New York and London: Routledge.

Khasanzyanova, A. (2017). How volunteering helps students to develop soft skills. International Review of Education, 63(3), 363-379.

Kilcommins, S. (2015). Capstone courses as a vehicle for integrative learning. In D. Blackshields, J. Cronin, B. Higgs, S. Kilcommins, M. McCarthy, \& A. Ryan (Eds.), Integrative learning: International research and practice (pp. 143-156). Abingdon, UK: Routledge.

Kim, J., Erdem, M., Byun, J., \& Jeong, H. (2011). Training soft skills via e-learning: International chain hotels. International Journal of Contemporary Hospitality Management, 23(6), 739-763.

Lawson, R., Taylor, T., Fallshaw, E., Summers, J., Kinash, S., French, E., \& AngusLeppan, T. (2013). Hunters and gatherers: Strategies for curriculum mapping and data collection for assuring learning. Retrieved from https://bit.ly/2DqAWgk

Lawson, R., Taylor, T., Thompson, D., Simpson, L., Freeman, M., Treleaven, L., \& Rohde, F. (2012). Engaging with graduate attributes through encouraging accurate student self-assessment. Asian Social Science, 8(4), 3-12.

Leach, L. (2012). Optional self-assessment: Some tensions and dilemmas. Assessment \& Evaluation in Higher Education, 37(2), 137-147.

Leong, R., \& Kavanagh, M. (2013). A work integrated learning (WIL) framework to develop graduate skills and attributes in an Australian university's accounting program. Asia-Pacific Journal of Cooperative Education, 14(1), 1-14.

Lewis, L. (2019). Organizational change: Creating change through strategic communication (2nd edn). Hoboken, NJ: Wiley-Blackwell.

Marek, K. (2012). Knowledge production in European universities: States, markets, and academic entrepreneurialism (Vol. 3). Frankfurt: Peter Lang.

McMahon, M., Luca, J., \& John, C. (2007). A self-assessment tool to help learners develop teamwork skills. Retrieved from https://bit.ly/2IPlHkh

Nelson, B. (2002). Striving for quality: Learning, teaching and scholarship. Canberra: Department of Education, Science and Training.

Nguyen, D. M., Truong, T. V., \& Le, N. B. (2013). Deployment of capstone projects in software engineering education at Duy Tan University as part of a university-wide projectbased learning effort. Retrieved from https://bit.ly/2UzJDKO 
Nguyen, P. T. M., Cornish, L., \& Minichiello, V. (2014). Management, leadership and change: Views from rectors, vice-rectors and academic staff in Vietnamese higher education institutions. Asia Pacific Journal of Educational Development (APJED), 3(1), 69-77.

Nikitina, L., \& Furuoka, F. (2012). Sharp focus on soft skills: A case study of Malaysian university students' educational expectations. Educational Research for Policy and Practice, 11(3), 207-224.

Njue, C., \& Ongoto, H. (2018). Strategic management practices and change implementation in selected public universities in Kenya. International Academic Journal of Human Resource and Business Administration, 3(4), 124-149.

O'Connor, K., Lynch, K., \& Owen, D. (2011). Student-community engagement and the development of graduate attributes. Education + Training, 53(2/3), 100-115.

O’Neill, G. (2010). A programme wide approach to assessment: A reflection on some curriculum mapping tools. Paper presented at the AISHE Conference, Dublin, Ireland. Retrieved from https://bit.ly/2Vhrl6W

Palmer, S., Holt, D., Hall, W., \& Ferguson, C. (2011). An evaluation of an online student portfolio for the development of engineering graduate attributes. Computer Applications in Engineering Education, 19(3), 447-456.

Pitman, T., \& Broomhall, S. (2009). Australian universities, generic skills and lifelong learning. International Journal of Lifelong Education, 28(4), 439-458.

Quarrie, S. P. (2007). Student peer review as a tool for efficiently achieving subject-specific and generic learning outcomes: Examples in botany at the Faculty of Agriculture, University of Belgrade. Higher Education in Europe, 32(2-3), 203-212.

Rowley, J., Munday, J., \& Polly, P. (2017). Preparing future career ready professionals: $A$ portfolio process to develop critical thinking using digital learning and teaching. Retrieved from https://bit.ly/2vjLdpS

Rychen, D. S., \& Salganik, L. H. (2003). Key competencies for a successful life and wellfunctioning society. Cambridge, MA: Hogrefe Publishing.

Scarinci, J., \& Pearce, P. (2012). The perceived influence of travel experiences on learning generic skills. Tourism Management, 33(2), 380-386.

Shek, D. T., \& Chak, Y. L. (2019). Perceived changes and benefits of a service-learning subject for underprivileged children in Shanghai: Views of university students. In D. T. L. Shek, G. Ngai, \& S. C. F. Chan (Eds.), Service-learning for youth leadership: The case of Hong Kong (pp. 33-47). Singapore: Springer.

Sin, C., Tavares, O., \& Amaral, A. (2017). Accepting employability as a purpose of higher education? Academics' perceptions and practices. Studies in Higher Education. doi: $10.1080 / 03075079.2017 .1402174$

Sin, S., Jones, A., \& Petocz, P. (2007). Evaluating a method of integrating generic skills with accounting content based on a functional theory of meaning. Accounting \& Finance, 47(1), 143-163.

Skoumpopoulou, D., \& Waring, T. (2017). Cultural change through the implementation of an enterprise system: A UK university case study. Journal of Enterprise Information Management, 30(5), 809-830.

Smith, C., \& Worsfold, K. (2015). Unpacking the learning-work nexus: 'Priming' as lever for high-quality learning outcomes in work-integrated learning curricula. Studies in Higher Education, 40(1), 22-42.

Star, C., \& Hammer, S. (2008). Teaching generic skills: Eroding the higher purpose of universities, or an opportunity for renewal? Oxford Review of Education, 34(2), 237-251. 
Šuba, P. (2017). Motives for young people to volunteer abroad: A case study of AIESEC interns from the perspective of volunteer tourism. African Journal of Hospitality, Tourism and Leisure, 6(3), 1-11.

Talukdar, J., Aspland, T., \& Datta, P. (2013). Australian higher education and the course experience questionnaire: Insights, implications and recommendations. Australian Universities' Review, 55(1), 27-35.

Tang, T. T., \& Yi-Fang, L. (2014). Stakeholders' perspectives on quality assurance in Vietnamese higher education. Higher Education Evaluation and Development, 8(2), 1-30. doi: 10.6197/HEED.2014.0802.01

Taylor, E. (2016). Investigating the perception of stakeholders on soft skills development of students: Evidence from South Africa. Interdisciplinary Journal of e-Skills and Lifelong Learning, 12(1), 1-18.

Tertiary Education Quality and Standards Agency (2013). Australian qualifications framework. Canberra: The Australian Qualifications Framework Council. Retrieved from https://bit.ly/ 2UxTUHm

Thai Government (2006). National qualifications framework for higher education in Thailand. Retrieved from https://bit.ly/2DsbFSX

The Quality Assurance Agency for Higher Education (2014). The frameworks for higher education qualifications of UK degree-awarding bodies. Retrieved from https://bit.ly/2W9jX9i

Tran, L. H. N., \& Nguyen, T. M. D. (2018). Internship-related learning outcomes and their influential factors: The case of Vietnamese tourism and hospitality students. Education + Training, 60(1), 69-81.

Tran, T. T. (2015). Is graduate employability the 'whole-of-higher-education-issue'? Journal of Education and Work, 28(3), 207-227.

Tremblay, K., Lalancette, D., \& Roseveare, D. (2012). Assessment of higher education learning outcomes. Retrieved from https://bit.ly/2IRTRnB

Vogler, J. S., Thompson, P., Davis, D. W., Mayfield, B. E., Finley, P. M., \& Yasseri, D. (2018). The hard work of soft skills: Augmenting the project-based learning experience with interdisciplinary teamwork. Instructional Science, 46(3), 457-488.

Williamson, I., Wildbur, D., Bell, K., Tanner, J., \& Matthews, H. (2018). Benefits to university students through volunteering in a health context: A new model. British Journal of Educational Studies, 66(3), 383-402.

Yassin, S., Hasan, F. A., Amin, W., \& Amiruddin, N. (2008). Implementation of generic skills in the curriculum. Retrieved from https://bit.ly/2UQcQGh

Yin, H., Lu, G., \& Wang, W. (2014). Unmasking the teaching quality of higher education: Students' course experience and approaches to learning in China. Assessment \& Evaluation in Higher Education, 39(8), 949-970.

Anh, H. (2011). 94\% sinh viên ra trường phải đào tạo tiếp. Thanh Nien Online, 1 Dec. Retrieved from https://bit.ly/2W9Hcjy

Berggren, K.-F., Brodeur, D., Crawley, E. F., Ingemarsson, I., Litant, W. T., Malmqvist, J., \& Östlund, S. (2003). CDIO: An international initiative for reforming engineering education. World Transactions on Engineering and Technology Education, 2(1), 49-52.

Bodewig, C., \& Badiani-Magnusson, R. (2014). Skilling up Vietnam: Preparing the workforce for a modern market economy. Washington DC: World Bank Publications.

Cao, L. (2000). Reflections on market reform in post-war, post-embargo Vietnam. Retrieved from: https://scholarship.law.wm.edu/facpubs/145

Cui, D. (2007). A weakness in Confucianism: Private and public moralities. Frontiers of Philosophy in China, 2(4), 517-532. 
Dao, K. V. (2015). Key challenges in the reform of governance, quality assurance, and finance in Vietnamese higher education: A case study. Studies in Higher Education, 40(5), 745-760.

Dao, V. K., \& Hayden, M. (2010). Reforming the governance of higher education in Vietnam. In G. Harman, M. Hayden, \& T. N. Pham (Eds.), Reforming higher education in Vietnam (pp. 129-142). New York, NY: Springer.

Dien, A. (2014). Vietnam's cheap labour may turn out to be a hard sell. Thanh Nien News, 5 March. Retrieved from https://bit.ly/2Wl0GXP

Do, Q. T., Pham, H. T., \& Nguyen, K. D. (2017). Quality assurance in the Vietnamese higher education: A top-down approach and compliance-driven QA. In M. Shah \& Q. T. N. Do (Eds.), The rise of quality assurance in Asian higher education (pp. 191-207). Cambridge, MA: Elsevier.

Doan, D. H. (2005). Moral education or political education in the Vietnamese educational system? Journal of Moral Education, 34(4), 451-463.

Evans, K., \& Rorris, A. (2010). Optimising the impact of Vietnam's higher education sector on socio-economic development. In G. Harman, M. Hayden, \& T. N. Pham (Eds.), Reforming higher education in Vietnam (pp. 167-181). New York, NY: Springer.

Fatseas, M. (2010). Research-industry cooperation supporting development in Vietnam: The challenge of translating policy into practice. In G. Harman, M. Hayden, \& T. N. Pham (Eds.), Reforming higher education in Vietnam (pp. 103-115). New York, NY: Springer.

Gates, C. L. (1995). Enterprise reform and Vietnam's transformation to a market-oriented economy. ASEAN Economic Bulletin, 12(1), 29-52.

General Statistics Office of Vietnam (2019a). Dân số trung bình phân theo giới tính và thành thị, nông thôn (Population ratio according to genders and living areas). Retrieved from www.gso.gov.vn/default.aspx?tabid=714

General Statistics Office of Vietnam (2019b). Giáo duc đại họ và cao d®ng (Higher education and vocational education). Retrieved from https://gso.gov.vn/default.aspx?ta bid $=722$.

Ha, T. (2015). Businesses more concerned about human resources quality. Vietnam Business Forum, 13 August. Retrieved from http://vccinews.com/news_detail.asp?news_id=32452

Hadad, S. (2017). Knowledge economy: Characteristics and dimensions. Management Dynamics in the Knowledge Economy, 5(2), 203-225.

Harman, G., Hayden, M., \& Nghi, P. T. (2010). Higher education in Vietnam: Reform, challenges and priorities. New York, NY: Springer.

Harman, G., \& Le, T. B. N. (2010). The research role of Vietnam's universities. In G. Harman, M. Hayden, \& T. N. Pham (Eds.), Reforming higher education in Vietnam (pp. 87-102). New York, NY: Springer.

Harman, K., \& Bich, N. T. N. (2010). Reforming teaching and learning in Vietnam's higher education system. In G. Harman, M. Hayden, \& P. T. Nghi (Eds.), Reforming higher education in Vietnam: Challenges and priorities (pp. 65-86). New York, NY: Springer.

Hoang, L. (2018). Twin privatization in Vietnam higher education: The emergence of private higher education and partial privatization of public universities. Higher Education Policy. doi: 10.1057/s41307-018-0086-8

Huong, P. L., \& Fry, G. W. (2002). The emergence of private higher education in Vietnam: Challenges and opportunities. Educational Research for Policy and Practice, 1(1-2), 127-141.

Huong, P. L., \& Fry, G. W. (2004). Education and economic, political, and social change in Vietnam. Educational Research for Policy and Practice, 3(3), 199-222.

Irvin, G. (1995). Vietnam: Assessing the achievements of Doi Moi. The Journal of Development Studies, 31(5), 725-750. 
Jurje, F., \& Lavenex, S. (2015). ASEAN Economic Community: What model for labour mobility. Retrieved from https://bit.ly/2vkoEBI.

Kim, H., \& Mobrand, E. (2019). Stealth marketisation: How international school policy is quietly challenging education systems in Asia. Globalisation, Societies and Education. doi: $10.1080 / 14767724.2019 .1571405$.

Lagemann, E. C., \& Lewis, H. (2015). What is college for? The public purpose of higher education. New York, NY: Teachers College Press.

Le, B. V., Le, H. M., \& Giang, P. (2017). Implementing the credit-based education model in Vietnamese universities. Tropicultura, 34, 20-30. Retrieved from www.tropicultura. org/text/v34ns/20.pdf

London, J. D. (2006). Vietnam: The political economy of education in a "Socialist" periphery. Asia Pacific Journal of Education, 26(1), 1-20.

Ly, T. H. (2015). Confucian influences on Vietnamese culture. Vietnam Social Sciences, 5 , 71-82. Retrieved from https://bit.ly/2Vkd4VB

ManPowerGroup (2011). Building a high-skilled economy: A new Vietnam. Retrieved from https://bit.ly/2XCRMjz

Menon, J., \& Melendez, A. C. (2017). Realizing an Asean Economic Community: Progress and remaining challenge. The Singapore Economic Review, 62(3), 681-702.

MOET (2010). Công văn 2916/ BGDĐT-GDĐH hương dân xây dụng và công bố chuẩn đầu ra ngành đào tạ. Retrieved from https://bit.ly/2VlKS4I

MOET (2014). Quyết định số 70/2014/QĐ-TTg của Thu tuớng Chính phủ: Ban hành Điều lẹ truòng đại họ. Retrieved from https://bit.ly/2ID92lp

Nguyen, H. (2015). Globalization, consumerism, and the emergence of teens in contemporary Vietnam. Journal of Social History, 49(1), 4-19.

Nguyen, H. T., Walkinshaw, I., \& Pham, H. H. (2017). EMI programs in a Vietnamese university: Language, pedagogy and policy issues. In B. Fenton-Smith, P. Humphreys, \& I. Walkinshaw (Eds.), English medium instruction in higher education in Asia-Pacific (pp. 37-52). Cham, Switzerland: Springer.

Nguyen, M. T. (2011). Vietnamese students' employability skills. International Education Studies, 4(4), 175.

Nguyen, N. D., Ngoc, N. B., \& Montague, A. (2019). Enhancing graduate work-readiness in Vietnam. In S. Dhakal, V. Prikshat, A. Nankervis, \& J. Burgess (Eds.), The Transition from graduation to work (pp. 221-237). Singapore: Springer.

Nguyen, Q. (2018). Xây dựng Chiến lược t冈ng thể phát triển giáo dục đại học ở Việt Nam. Nhan Dan, 29 March. Retrieved from https://bit.ly/2GrRHbA

Nguyen, T. (2016,). Employers lament lack of soft skills in graduates. University World News, 22 Jan. Retrieved from https://bit.ly/2ZsVDRT

Nguyen, T. L. H. (2013). Middle-level academic management: A case study on the roles of the heads of department at a Vietnamese university. Tertiary Education and Management, 19(1). doi: 10.1080/13583883.2012.724704

Nguyen, T. N. (2018). Issues in soft skills development for Vietnamese students in current undergraduate programs. Tap chi Khoa hoc, 15(7), 114-124.

Nordeatrade (2019). The economic context of Vietnam. Retrieved from https://bit.ly/2Uv58fW

Pham, H. (2013). Graduate unemployment and 'over-education' rising. University World News, 13 July. Retrieved from https://bit.ly/2IPY5w7

Pham, H. (2014). Vietnam: Aiming for at least one world-class university by 2020. University World News, 24 Jan. Retrieved from https://bit.ly/2IPZ8Mn

Prime Minister (2001). Quyết định 201/2001/QĐ-TTg của Thủ tuớng Chính Phủ phê duyệt Chiến lục phát triển giáo duc 2001-2010 (Prime Minister's decision 201/2001/QĐ-TTg 
on approval of the educational development strategy 2001-2010). Retrieved from https:// bit.ly/2GD9QEA

Prime Minister (2012). Quyết định $711 / Q Đ-T T g$ về việc phê duyệt chiến huợc phát triển giáo duc 2011-2020 (Decision 711/QD-TTg on the approval of the educational development strategy for 2011-2020). Retrieved from https://bit.ly/2vhzkRg

Sanders, S. R. (2014). North versus south: The effects of foreign direct investment and historical legacies on poverty reduction in post-Đ囚i Mới Vietnam. Journal of Vietnamese Studies, 9(2), 46-67.

Schaumburg-Müller, H., \& Chuong, P. H. (2010). The new Asian dragon: Internationalization of firms in Vietnam. Copenhagen: Copenhagen Business School Press.

Tang, T. T., \& Yi-Fang, L. (2014). Stakeholders' perspectives on quality assurance in Vietnamese higher education. Higher Education Evaluation and Development, 8(2), 1-30. doi: 10.6197/HEED.2014.0802.01

Tran, H. T., \& Santarelli, E. (2018). Successful transition to a market economy in Vietnam: An interpretation from organizational ecology theory. Retrieved from www.econstor.eu/ bitstream/10419/174886/1/GLO-DP-0181.pdf

Tran, L. H. N. (2017). Developing employability skills via extra-curricular activities in Vietnamese universities: Student engagement and inhibitors of their engagement. Journal of Education and Work, 30(8), 854-867.

Tran, L. H. N. (2018a). Game of blames: Higher education stakeholders' perceptions of causes of Vietnamese graduates' skills gap. International Journal of Educational Development, 62(Sep), 302-312.

Tran, L. H. N. (2018b). The skills gap of Vietnamese graduates and final-year university students. Journal of Education and Work, 31(7-8), 579-594.

Tran, L. H. N., Hoang, T. G., \& Vo, P. Q. (2019). At-home international education in Vietnamese universities: Impact on graduates' employability and career prospects. Higher Education. doi: 10.1007/s10734-10019-00372-w

Tran, L. H. N., Phan, T. N. P., \& Tran, L. K. H. (2018). Implementing the studentcentred teaching approach in Vietnamese universities: The influence of leadership and management practices on teacher engagement. Educational Studies. doi: 10.1080/ 03055698.2018.1555453

Tran, L. T., Le, T. T. T., \& Nguyen, N. T. (2014). Curriculum and pedagogy. In Higher education in Vietnam: Flexibility, mobility and practicality in the global knowledge economy (pp. 86-107). London: Palgrave Macmillan.

Tran, L. T., \& Marginson, S. (2018a). Internationalisation of Vietnamese higher education: An overview. In L. T. Tran \& S. Marginson (Eds.), Internationalisation in Vietnamese higher education (pp. 1-16). Cham, Switzerland: Springer.

Tran, L. T., \& Marginson, S. (2018b). Internationalisation of Vietnamese higher education: Possibilities, challenges and implications. In L. T. Tran \& S. Marginson (Eds.), Internationalisation in Vietnamese higher education (pp. 253-257). Cham, Switzerland: Springer.

Tran, L. T., Ngo, M., Nguyen, N., \& Dang, X. T. (2017). Hybridity in Vietnamese universities: An analysis of the interactions between Vietnamese traditions and foreign influences. Studies in Higher Education, 42(10), 1899-1916.

Tran, L. T., \& Nguyen, H. T. (2018). Internationalisation of higher education in Vietnam through English Medium Instruction (EMI): Practices, tensions and implications for local language policies. In I. Liyanage (Ed.), Multilingual education yearbook 2018 (pp. 91-106). Cham, Switzerland: Springer.

Tran, T. T. (2013). Limitation on the development of skills in higher education in Vietnam. Higher Education, 65(5), 631-644. 
Tran, T. T. (2015). Is graduate employability the 'whole-of-higher-education-issue'? Journal of Education and Work, 28(3), 207-227.

Tran, V. T. (2013). Vietnamese economy at the crossroads: New doi moi for sustained growth. Asian Economic Policy Review, 8(1), 122-143.

Trung, T. Q., \& Swierczek, F. W. (2009). Skills development in higher education in Vietnam. Asia Pacific Business Review, 15(4), 565-586.

Truong, H. T., Laura, R. S., \& Shaw, K. (2016). New insights for soft skills development in Vietnamese business schools: Defining essential soft skills for maximizing graduates' career success. International Journal of Social, Behavioral, Educational, Economic, Business and. Industrial Engineering, 10(6), 1857-1863.

Truong, Q. D., \& Metzger, C. (2007). Quality of business graduates in Vietnamese institutions: Multiple perspectives. Journal of Management Development, 26(7), 629-643.

Vietnamese Congress (2011). Nghi quyêt đại hội đại biểu toàn quốc là̀n thư XI Đảng Cộng Sản Việt Nam. Retrieved from https://bit.ly/2ZsfUXZ

Vietnamese Congress (2016). Nghị quyết Đại hội làn thí XII của Đảng. Retrieved from https://bit.ly/2XG7R8h

Vietnamese Government (2012). Lu凶t giáo duc đại học. Retrieved from https://bit.ly/ 2GNGV24

Vietnamese Government (2015). Nghị định: Quy định tiêu chuẩn phân tầng, khung xếp hạng và tiêu chuẩn xếp hạng cơ s区 giáo duc đại học (73/2015/NĐ-CP). Retrieved from https://bit.ly/2VnRgbJ

Vietnamese Government (2018). Nghị định số 86/2018/NĐ-CP của Chính phủ : Quy định về hợp tác, đầu tue của nuớc ngoài trong lĩnh vưc giáo duc (Government's Decision 86/ 2018/NÐ-CP on regulations on cooperation and investment in education with foreign stakeholders). Retrieved from https://bit.ly/2W53Qty

Vietnamnet (2018). Japan leads foreign investors in Vietnam in 2018. 29 Dec. Retrieved from: https://bit.ly/2WOskHc

Vo, H.-P., Berglund, A., \& Daniels, M. (2017). A perspective from Vietnamese students on teaching of soft skills. Paper presented at the International Conference on Learning and Teaching in Computing and Engineering (LaTICE). Retrieved from https://ieexp lore.ieee.org/document/8064426

Welch, A. R. (2010). Internationalisation of Vietnamese higher education: Retrospect and prospect. In G. Harman, M. Hayden, \& T. N. Pham (Eds.), Reforming higher education in Vietnam (pp. 197-213). New York, NY: Springer.

World Bank (2008). Vietnam: Higher education and skills for growth. Retrieved from http s://openknowledge.worldbank.org/handle/10986/7814

Adnan, Y. M., Daud, M. N., Alias, A., \& Razali, M. N. (2017). Importance of soft skills for graduates in the real estate programmes in Malaysia. Journal of Surveying, Construction and Property, 3(2). doi: https://doi.org/10.22452/jscp.vol3no2.4

Al-Mahmood, R., \& Gruba, P. (2007). Approaches to the implementation of generic graduate attributes in Australian ICT undergraduate education. Computer Science Education, 17(3), 171-185.

Anh, H. (2011). 94\% sinh viên ra trường phải đào tạo tiếp. Thanh Nien Online, 1 Dec. Retrieved from https://bit.ly/2W9Hcjy

Barrie, S., Hughes, C., Smith, C., \& Thomson, K. (2009). The national graduate attributes project: Key issues to consider in the renewal of learning and teaching experiences to foster graduate attributes. Sydney, Australia: Australian Learning and Teaching Council.

Bodewig, C., \& Badiani-Magnusson, R. (2014). Skilling up Vietnam: Preparing the workforce for a modern market economy. Washington DC: World Bank Publications. 
Brodie, L. (2011). Delivering key graduate attributes via teams working in virtual space. International Journal of Emerging Technologies in Learning (iJET), 6(3), 5-11.

de la Harpe, B., \& David, C. (2012). Major influences on the teaching and assessment of graduate attributes. Higher Education Research \& Development, 31(4), 493-510.

Eike, R. J., Myers, B., \& Sturges, D. (2018). The impact of service-learning targeting apparel design majors: A qualitative analysis of learning growth. Family and Consumer Sciences Research Journal, 46(3), 267-281.

Elo, S., \& Kyngäs, H. (2008). The qualitative content analysis process. Journal of Advanced Nursing, 62(1), 107-115.

Fleming, J., Donovan, R., Beer, C., \& Clark, D. (2013). A whole of university approach to embedding graduate attributes: A reflection. In J. Willems, B. Tynan, \& R. James (Eds.), Global challenges and perspectives in blended and distance learning (pp. 246-257). Hershey, PA: IGI Global.

Hager, P., \& Holland, S. (2006). Graduate attributes, learning and employability (Vol. 6). Dordrecht, Netherlands: Springer Science \& Business Media.

Harman, G., Hayden, M., \& Nghi, P. T. (2010). Higher education in Vietnam: Reform, challenges and priorities. New York, NY: Springer.

Harman, K., \& Bich, N. T. N. (2010). Reforming teaching and learning in Vietnam's higher education system. In G. Harman, M. Hayden, \& P. T. Nghi (Eds.), Reforming higher education in Vietnam: Challenges and priorities (pp. 65-86). New York, NY: Springer.

Hendriana, H., Johanto, T., \& Sumarmo, U. (2018). The role of problem-based learning to improve students' mathematical problem-solving ability and self-confidence. Journal on Mathematics Education, 9(2), 291-300.

Huong, P. L., \& Fry, G. W. (2011). Vietnam as an outlier: Tradition and change in education. In C. Brock \& L. P. Symaco (Eds.), Education in South-East Asia (pp. 221-243). Oxford, UK: Symposim Books

Hurrell, S. A. (2016). Rethinking the soft skills deficit blame game: Employers, skills withdrawal and the reporting of soft skills gaps. Human Relations, 69(3), 605-628.

Ibrahim, M. E., Al-Shahrani, A. M., Abdalla, M. E., Abubaker, I. M., \& Mohamed, M. E. (2018). The effectiveness of problem-based learning in acquisition of knowledge, soft skills during basic and preclinical sciences: Medical students' points of view. Acta Informatica Medica, 26(2), 119-124.

International Labour Organisation and Asian Development Bank (2014). ASEAN community 2015: Managing integration for better jobs and shared prosperity. Retrieved from https://bit.ly/2GzAgpI

Jääskelä, P., Nykänen, S., \& Tynjälä, P. (2018). Models for the development of generic skills in Finnish higher education. Journal of Further and Higher Education, 42(1), 130-142.

Jones, A. (2009). Generic attributes as espoused theory: The importance of context. Higher Education, 58(2), 175-191.

Jones, A. (2010). Generic attributes in accounting: The significance of the disciplinary context. Accounting Education: An International Journal, 19(1-2), 5-21.

Jones, M., Baldi, C., Phillips, C., \& Waikar, A. (2017). The hard truth about soft skills: What recruiters look for in business graduates. College Student Journal, 50(3), 422-428.

Kinash, S., Crane, L., Schulz, M., Dowling, D., \& Knight, C. (2014). Improving graduate employability: Strategies from three universities. Retrieved from https://bit.ly/2XG2juv

Losekoot, E., Lasten, E., Lawson, A., \& Chen, B. (2018). The development of soft skills during internships: The hospitality student's voice. Research in Hospitality Management, $8(2), 155-159$. 
Mak, B., Lau, C., \& Wong, A. (2017). Effects of experiential learning on students: An ecotourism service-learning course. Journal of Teaching in Travel \& Tourism, 17(2), 85-100.

Marcus, B., Weigelt, O., Hergert, J., Gurt, J., \& Gelléri, P. (2017). The use of snowball sampling for multi source organizational research: Some cause for concern. Personnel Psychology, 70(3), 635-673.

Marginson, S. (2011). Higher education in East Asia and Singapore: Rise of the Confucian model. Higher Education, 61(5), 587-611.

Menon, J., \& Melendez, A. C. (2017). Realizing an Asean Economic Community: Progress and remaining challenge. The Singapore Economic Review, 62(3), 681-702.

MOET (2010). Công văn 2916/ BGDĐT-GDĐH hương dẫn xây dưng và công bố chuẩn đầu ra ngành đào tao. Retrieved from https://bit.ly/2VlKS4I

Myers, T., Blackman, A., Andersen, T., Hay, R., Lee, I., \& Gray, H. (2014). Cultivating ICT students' interpersonal soft skills in online learning environments using traditional active learning techniques. Journal of Learning Design, 7(3), 38-53.

Nghi, P. T., \& London, J. D. (2010). The higher education reform agenda: A vision for 2020. In G. Harman, M. Hayden, \& T. N. Pham (Eds.), Reforming higher education in Vietnam (pp. 51-64). New York, NY: Springer.

Nguyen, T. L. H. (2013). Middle-level academic management: A case study on the roles of the heads of department at a Vietnamese university. Tertiary Education and Management, 19(1). doi: 10.1080/13583883.2012.724704

O’Neill, G. (2010). A programme wide approach to assessment: A reflection on some curriculum mapping tools. Paper presented at the AISHE Conference, Dublin, Ireland. Retrieved from https://bit.ly/2Vhrl6W

Pitman, T., \& Broomhall, S. (2009). Australian universities, generic skills and lifelong learning. International Journal of Lifelong Education, 28(4), 439-458.

Stevens, M., \& Norman, R. (2016). Industry expectations of soft skills in IT graduates: A regional survey. Paper presented at the Australasian Computer Science Week Multiconference, 2-5 February, Canberra, Australia.

Tertiary Education Quality and Standards Agency (2013). Australian qualifications framework. Canberra: The Australian Qualifications Framework Council.

Tran, L. H. N. (2017). Developing generic skills for students via extra-curricular activities in Vietnamese universities: Practices and influential factors. Journal of Teaching and Learning for Graduate Employability, 8(1), 22.

Tran, L. H. N. (2018). The skills gap of Vietnamese graduates and final-year university students. Journal of Education and Work, 31(7-8), 579-594.

Tran, L. H. N., \& Nguyen, T. M. D. (2018). Internship-related learning outcomes and their influential factors: The case of Vietnamese tourism and hospitality students. Education + Training, 60(1), 69-81.

Tran, L. H. N., Phan, T. N. P., \& Tran, L. K. H. (2018). Implementing the student-centred teaching approach in Vietnamese universities: The influence of leadership and management practices on teacher engagement. Educational Studies. doi: 10.1080/ 03055698.2018 .1555453

Tran, L. T., Le, T. T. T., \& Nguyen, N. T. (2014). Curriculum and pedagogy. In Higher Education in Vietnam: Flexibility, Mobility and Practicality in the Global Knowledge Economy (pp. 86-107). London: Palgrave Macmillan.

Tran, L. T., Marginson, S., Do, H. M., Do, Q. T. N., Le, T. T. T., Nguyen, N. T., ... Ho, T. T. H. (2014). Higher education in Vietnam: Flexibility, mobility and practicality in the global knowledge economy. New York, NY: Palgrave MacMillan. 
Tran, N. C. (2009). Reaching out to society: Vietnamese universities in transition. Science and Public Policy, 36(2), 91-95.

Tran, N. T. (2013). Vietnamese Parents' Attitudes Towards Western Parenting Behaviors and Interventions. Nashville, TN: Vanderbilt University.

Tran, T. T. (2016). Building a close connection between higher education and industry for a better education outcome for Vietnam. VNU Journal of Science, 32(4), 36-43.

Varghese, N. (2007). GATS and higher education: The need for regulatory policies. Paris: International Institute for Educational Planning.

Vietnamese Government (2012). Lu凶t giáo duc đại học. Retrieved from https://bit.ly/ 2GNGV24

Willcoxson, L., Wynder, M., \& Laing, G. K. (2010). A whole-of-program approach to the development of generic and professional skills in a university accounting program. Accounting Education: An International Journal, 19(1-2), 65-91.

World Bank (2008). Vietnam: Higher education and skills for growth. Retrieved from http s://openknowledge.worldbank.org/handle/10986/7814

World Bank (2018). The World Bank in Vietnam. www.worldbank.org/en/country/viet nam/overview

Yin, R. K. (2009). Case Study Research, Design \& Methods (4th edn). Thousand Oaks, CA: Sage.

Al-Mahmood, R., \& Gruba, P. (2007). Approaches to the implementation of generic graduate attributes in Australian ICT undergraduate education. Computer Science Education, 17(3), 171-185.

Ang, L., D'Alessandro, S., \& Winzar, H. (2014). A visual-based approach to the mapping of generic skills: Its application to a Marketing degree. Higher Education Research \& Development, 33(2), 181-197.

Barrie, S., Hughes, C., Smith, C., \& Thomson, K. (2009). The national graduate attributes project: Key issues to consider in the renewal of learning and teaching experiences to foster graduate attributes. Sydney: Australian Learning and Teaching Council.

Bourdieu, P. (1977). Outline of a theory of practice (Vol. 16). New York: Cambridge University Press.

Bourdieu, P. (1989). Social space and symbolic power. Sociological Theory, 7(1), 14-25.

Bourdieu, P., \& Wacquant, L. (1992). An invitation to reflexive sociology. Cambridge: Polity.

Camillo, A. A. (2015). Handbook of research on global hospitality and tourism management. Hershey, PA: IGI Global.

Dao, K. V. (2015). Key challenges in the reform of governance, quality assurance, and finance in Vietnamese higher education: A case study. Studies in Higher Education, 40(5), 745-760.

de la Harpe, B., \& David, C. (2012). Major influences on the teaching and assessment of graduate attributes. Higher Education Research \& Development, 31(4), 493-510.

Do, H. M., \& Do, Q. T. N. (2014). Higher and tertiary education in Vietnam. In Higher education in Vietnam: Flexibility, mobility and practicality in the global knowledge economy (pp. 29-53). London: Palgrave Macmillan.

Dumenden, I. E., \& English, R. (2013). Fish out of water: refugee and international students in mainstream Australian schools. International Journal of Inclusive Education, 17(10), 1078-1088.

Eike, R. J., Myers, B., \& Sturges, D. (2018). The impact of service-learning targeting apparel design majors: A qualitative analysis of learning growth. Family and Consumer Sciences Research Journal, 46(3), 267-281.

Elo, S., \& Kyngäs, H. (2008). The qualitative content analysis process. Journal of Advanced Nursing, 62(1), 107-115. 
Hardy, I. (2009). Critiquing teacher professional development: Teacher learning within the field of teachers' work. Critical Studies in Education, 51(1), 71-84.

Harman, K., \& Bich, N. T. N. (2010). Reforming teaching and learning in Vietnam's higher education system. In G. Harman, M. Hayden, \& P. T. Nghi (Eds.), Reforming higher education in Vietnam: Challenges and priorities (pp. 65-86). New York, NY: Springer.

Hayden, M., \& Lam, T. Q. (2010). Vietnam's higher education system. In G. Harman, M. Hayden, \& N. T. Pham (Eds.), Reforming higher education in Vietnam (pp. 14-29). New York, NY: Springer.

Henderson, A., \& Trede, F. (2017). Strengthening attainment of student learning outcomes during work-integrated learning: A collaborative governance framework across academia, industry and students. Asia-Pacific Journal of Cooperative Education, 18(1), 73-80.

Hendriana, H., Johanto, T., \& Sumarmo, U. (2018). The role of problem-based learning to improve students' mathematical problem-solving ability and self-confidence. Journal on Mathematics Education, 9(2), 291-300.

James, N., Busher, H., \& Suttill, B. (2015). Using habitus and field to explore Access to Higher Education students' learning identities. Studies in the Education of Adults, 47(1), 4-20.

Jones, A. (2009). Generic attributes as espoused theory: The importance of context. Higher Education, 58(2), 175-191.

Marcus, B., Weigelt, O., Hergert, J., Gurt, J., \& Gelléri, P. (2017). The use of snowball sampling for multi-source organizational research: Some cause for concern. Personnel Psychology, 70(3), 635-673.

Marginson, S. (2011). Higher education in East Asia and Singapore: Rise of the Confucian model. Higher Education, 61(5), 587-611.

Merriam, S. B. (2009). Qualitative research: A guide to design and implementation. San Francisco, CA: Jossey-Bass.

MOET (2010). Công văn 2916/ BGDĐT-GDĐH huớng dẫn xây dụng và công bố chuẩn đầu ra ngành đào tao. Retrieved from https://bit.ly/2VlKS4I

Nguyen, T. Q. T. (2017). Maintaining teachers' face in the context of change: Results from a study of Vietnamese college lecturers' perceptions of face. Teachers and Teaching, 23(1), 78-90.

Palmer, S., Holt, D., Hall, W., \& Ferguson, C. (2011). An evaluation of an online student portfolio for the development of engineering graduate attributes. Computer Applications in Engineering Education, 19(3), 447-456.

Pham, T. H. T. (2010). Implementing a student-centered learning approach at Vietnamese higher education institutions: Barriers under layers of casual layered analysis. Journal of Futures Studies, 15(1), 21-38.

Phuong, H. (2018). Luật Giáo dục Đại học cản trở đổi mới. Phap Luat, 14 March. Retrieved from https://bit.ly/2UAomAL

Quarrie, S. P. (2007). Student peer review as a tool for efficiently achieving subject-specific and generic learning outcomes: Examples in botany at the Faculty of Agriculture, University of Belgrade. Higher Education in Europe, 32(2-3), 203-212.

Ravasi, D., \& Schultz, M. (2006). Responding to organizational identity threats: Exploring the role of organizational culture. Academy of Management Journal, 49(3), $433-458$.

Robley, W., Whittle, S., \& Murdoch-Eaton, D. (2005). Mapping generic skills curricula: A recommended methodology. Journal of Further and Higher Education, 29(3), 221-231.

Roulin, N., \& Bangerter, A. (2013). Students' use of extra-curricular activities for positional advantage in competitive job markets. Journal of Education and Work, 26(1), 21-47. 
Schein, E. H. (2004). Organizational culture and leadership. San Francisco, CA: Jossey-Bass.

Scott, J. C. (2006). The mission of the university: Medieval to postmodern transformations. The Journal of Higher Education, 77(1), 1-39.

Siisiainen, M. (2003). Two concepts of social capital: Bourdieu vs. Putnam. International Journal of Contemporary Sociology, 40(2), 183-204.

Tran, L. T., Le, T. T. T., \& Nguyen, N. T. (2014). Curriculum and pedagogy. In Higher education in Vietnam: Flexibility, mobility and practicality in the global knowledge economy (pp. 86-107). London: Palgrave Macmillan.

Tran, T. T. (2015). Is graduate employability the 'whole-of-higher-education-issue'? Journal of Education and Work, 28(3), 207-227.

Truong, T. D., Hallinger, P., \& Sanga, K. (2017). Confucian values and school leadership in Vietnam: Exploring the influence of culture on principal decision making. Educational Management Administration \& Leadership, 45(1), 77-100. doi: 10.1177/ 1741143215607877

Vietnamese Government (2012). Luật giáo duc đại học. Retrieved from https://bit.ly/ 2GNGV24

Yin, R. K. (2009). Case study research, design \& methods (4th edn). Thousand Oaks, CA: Sage.

Adnan, Y. M., Daud, M. N., Alias, A., \& Razali, M. N. (2017). Importance of soft skills for graduates in the real estate programmes in Malaysia. Journal of Surveying, Construction and Property, 3(2). doi: 10.22452/jscp.vol3no2.4

Ajzen, I. (1991). The theory of planned behavior. Organizational Behavior and Human Decision Processes, 50(2), 179-211.

Anh, H. (2011). 94\% sinh viên ra truờng phải đào tạo tiếp. Thanh Nien Online, 1 Dec. Retrieved from https://bit.ly/2W9Hcjy

Assen, J., Meijers, F., Otting, H., \& Poell, R. (2016). Explaining discrepancies between teacher beliefs and teacher interventions in a problem-based learning environment: A mixed methods study. Teaching and Teacher Education, 60, 12-23.

Barrie, S., Hughes, C., \& Smith, C. (2009). The national graduate attributes project: Integration and assessment of graduate attributes in curriculum. Sydney: Australian Learning and Teaching Council.

Barrie, S., Hughes, C., Smith, C., \& Thomson, K. (2009). The national graduate attributes project: Key issues to consider in the renewal of learning and teaching experiences to foster graduate attributes. Sydney: Australian Learning and Teaching Council.

Bodewig, C., \& Badiani-Magnusson, R. (2014). Skilling up Vietnam: Preparing the workforce for a modern market economy. Washington, DC: World Bank Publications.

Bridgstock, R. (2009). The graduate attributes we've overlooked: Enhancing graduate employability through career management skills. Higher Education Research \& Development, 28(1), 31-44.

Browne, K. (2005). Snowball sampling: Using social networks to research non-heterosexual women. International Journal of Social Research Methodology, 8(1), 47-60.

Coates, H., \& Richardson, S. (2012). An international assessment of bachelor degree graduates' learning outcomes. Higher Education Management and Policy, 23(3), 1-19.

Cohen, L., Manion, L., \& Morison, K. (2018). Research methods in education. New York, NY: Routledge.

Dao, K. V. (2015). Key challenges in the reform of governance, quality assurance, and finance in Vietnamese higher education: A case study. Studies in Higher Education, 40(5), 745-760.

de la Harpe, B., \& David, C. (2012). Major influences on the teaching and assessment of graduate attributes. Higher Education Research \& Development, 31(4), 493-510. 
Eike, R. J., Myers, B., \& Sturges, D. (2018). The impact of service-learning targeting apparel design majors: A qualitative analysis of learning growth. Family and Consumer Sciences Research Journal, 46(3), 267-281.

Elo, S., \& Kyngäs, H. (2008). The qualitative content analysis process. Journal of Advanced Nursing, 62(1), 107-115.

Ertmer, P. A., Ottenbreit-Leftwich, A. T., Sadik, O., Sendurur, E., \& Sendurur, P. (2012). Teacher beliefs and technology integration practices: A critical relationship. Computers of Education, 59(2), 423-435.

Gayani Fernando, N., Amaratunga, D., \& Haigh, R. (2014). The career advancement of the professional women in the UK construction industry: The career success factors. Journal of Engineering, Design and Technology, 12(1), 53-70.

Giao Duc Viet Nam (2019). 63\% sinh viên th $₫ t$ nghiẹp khi ra truờng. Retrieved from http s://bit.ly/2Z19sqD

Hager, P., \& Holland, S. (2006). Graduate attributes, learning and employability (Vol. 6). Dordrecht, Netherlands: Springer Science \& Business Media.

Harman, K., \& Bich, N. T. N. (2010). Reforming teaching and learning in Vietnam's higher education system. In G. Harman, M. Hayden, \& P. T. Nghi (Eds.), Reforming higher education in Vietnam: Challenges and priorities (pp. 65-86). New York, NY: Springer.

Hayhoe, R., Li, J., Lin, J., \& Zha, Q. (2012). Portraits of 21st century Chinese universities: In the move to mass higher education (Vol. 30). Dordrecht, Netherlands: Springer Science \& Business Media.

Hendriana, H., Johanto, T., \& Sumarmo, U. (2018). The role of problem-based learning to improve students' mathematical problem-solving ability and self-confidence. Journal on Mathematics Education, 9(2), 291-300.

Humphreys, G., \& Wyatt, M. (2013). Helping Vietnamese university learners to become more autonomous. ELT Journal, 68(1), 52-63.

Hurrell, S. A. (2016). Rethinking the soft skills deficit blame game: Employers, skills withdrawal and the reporting of soft skills gaps. Human Relations, 69(3), 605-628.

Ibrahim, M. E., Al-Shahrani, A. M., Abdalla, M. E., Abubaker, I. M., \& Mohamed, M. E. (2018). The effectiveness of problem-based learning in acquisition of knowledge, soft skills during basic and preclinical sciences: Medical students' points of view. Acta Informatica Medica, 26(2), 119-124.

Jones, A. (2009). Generic attributes as espoused theory: The importance of context. Higher Education, 58(2), 175-191.

Linh, T. (2018). Nước ta đang có 5 triệu lao động trình độ đại học, 200 ngàn th囚t nghiệp. Giao Duc, 2 August. Retrieved from https://bit.ly/2ToWIep

Losekoot, E., Lasten, E., Lawson, A., \& Chen, B. (2018). The development of soft skills during internships: The hospitality student's voice. Research in Hospitality Management, $8(2), 155-159$.

Marginson, S. (2009). The knowledge economy and higher education: Rankings and classifications, research metrics and learning outcomes measures as a system for regulating the value of knowledge. Higher Education Management and Policy, 21(1), 1-15.

Marginson, S. (2011). Higher education in East Asia and Singapore: Rise of the Confucian model. Higher Education, 61(5), 587-611.

Ministry of Education and Training (2017). Số liệu chung về đại học năm học 2015-2016 và 2016-2017. Ha Noi, Vietnam: Ministry of Education and Training.

MOET (2010). Công văn 2916/BGDĐT-GDĐH huớng dẫn xây dụng và công bố chuẩn đầu ra ngành đào tao. Retrieved from https://bit.ly/2VlKS4I 
Myers, T., Blackman, A., Andersen, T., Hay, R., Lee, I., \& Gray, H. (2014). Cultivating ICT students' interpersonal soft skills in online learning environments using traditional active learning techniques. Journal of Learning Design, 7(3), 38-53.

Nickson, D., Warhurst, C., Commander, J., Hurrell, S. A., \& Cullen, A. M. (2012). Soft skills and employability: Evidence from UK retail. Economic and Industrial Democracy, 33(1), 65-84.

Palmer, S., Holt, D., Hall, W., \& Ferguson, C. (2011). An evaluation of an online student portfolio for the development of engineering graduate attributes. Computer Applications in Engineering Education, 19(3), 447-456.

Payton, J., Barnes, T., Buch, K., Rorrer, A., \& Zuo, H. (2015). The effects of integrating service learning into computer science: An inter-institutional longitudinal study. Computer Science Education, 25(3), 311-324.

Soh, K. (2017). The seven deadly sins of world university ranking: A summary from several papers. Journal of Higher Education Policy and Management, 39(1), 104-115.

Star, C., \& Hammer, S. (2008). Teaching generic skills: Eroding the higher purpose of universities, or an opportunity for renewal? Oxford Review of Education, 34(2), 237-251.

Temple, P. (2012). Universities in the knowledge economy: Higher education organisation and global change. New York: Routledge.

The Quality Assurance Agency for Higher Education (2014). The frameworks for higher education qualifications of UK degree-awarding bodies. Retrieved from: www.qaa.ac. uk/docs/qaa/quality-code/qualifications-frameworks.pdf

Tiwari, A., Das, A., \& Sharma, M. (2015). Inclusive education a "rhetoric" or "reality"? Teachers' perspectives and beliefs. Teaching and Teacher Education, 52, 128-136.

Tran, L. H. N. (2018). Game of blames: Higher education stakeholders' perceptions of causes of Vietnamese graduates' skills gap. International Journal of Educational Development, 62(Sep), 302-312.

Tran, L. H. N., \& Nguyen, T. M. D. (2018). Internship-related learning outcomes and their influential factors: The case of Vietnamese tourism and hospitality students. Education + Training, 60(1), 69-81.

Tran, L. H. N., Phan, T. N. P., \& Tran, L. K. H. (2018). Implementing the studentcentred teaching approach in Vietnamese universities: The influence of leadership and management practices on teacher engagement. Educational Studies. doi: 10.1080/ 03055698.2018 .1555453

Tran, L. T., Le, T. T. T., \& Nguyen, N. T. (2014). Curriculum and pedagogy. In Higher education in Vietnam: flexibility, mobility and practicality in the global knowledge economy (pp. 86-107). London: Palgrave Macmillan.

Tran, T. T. (2016). Building a close connection between higher education and industry for a better education outcome for Vietnam. VNU Journal of Science, 32(4), 36-43.

Yin, R. K. (2009). Case study research, design \& methods (4th edn). Thousand Oaks, CA: Sage.

Barrie, S., Hughes, C., Smith, C., \& Thomson, K. (2009). The national graduate attributes project: Key issues to consider in the renewal of learning and teaching experiences to foster graduate attributes. Sydney: Australian Learning and Teaching Council.

Bodewig, C., \& Badiani-Magnusson, R. (2014). Skilling up Vietnam: Preparing the workforce for a modern market economy. Washington, DC: World Bank Publications.

Browne, K. (2005). Snowball sampling: Using social networks to research non-heterosexual women. International Journal of Social Research Methodology, 8(1), 47-60.

Bunney, D., Sharplin, E., \& Howitt, C. (2015). Generic skills for graduate accountants: The bigger picture, a social and economic imperative in the new knowledge economy. Higher Education Research \& Development, 34(2), 256-269. 
Burke, K. (2010). Balanced assessment from formative to summative (Vol. 25). Portland, OR: Ringgold Inc.

Chanock, K., Clerehan, R., Moore, T., \& Prince, A. (2004). Shaping university teaching towards measurement for accountability: Problems of the graduate skills assessment test. Australian Universities' Review, 47(1), 22-29.

Cranney, J., Kofod, M., Huon, G., Jensen, L., Levin, K., McAlpine, I., Scoufis, M., \& Whitaker, N. (2012). Portfolio tools: Learning and teaching strategies to facilitate development of graduate attributes. Paper presented at the Proceedings of The Australian Conference on Science and Mathematics Education (formerly UniServe Science Conference). Retrieved from: https://bit.ly/2KSckTE

de la Harpe, B., \& David, C. (2012). Major influences on the teaching and assessment of graduate attributes. Higher Education Research \& Development, 31(4), 493-510.

Duong, V. A., \& Chua, C. S. (2016). English as a symbol of internationalization in higher education: A case study of Vietnam. Higher Education Research \& Development, 35(4), 669-683.

Elo, S., \& Kyngäs, H. (2008). The qualitative content analysis process. Journal of Advanced Nursing, 62(1), 107-115.

Gonczi, A. (2006). The OECD: Its role in the key competencies debate and in the promotion of lifelong learning. In P. Hager \& S. Holland (Eds.), Graduate attributes, learning and employability (pp. 105-124). Dordrecht, Netherlands: Springer.

Hager, P., \& Holland, S. (2006). Graduate attributes, learning and employability (Vol. 6). Dordrecht, Netherlands: Springer.

Harman, G., Hayden, M., \& Nghi, P. T. (2010). Higher education in Vietnam: Reform, challenges and priorities. New York, NY: Springer.

Harman, K., \& Bich, N. T. N. (2010). Reforming teaching and learning in Vietnam's higher education system. In G. Harman, M. Hayden, \& P. T. Nghi (Eds.), Reforming higher education in Vietnam: Challenges and priorities (pp. 65-86). New York, NY: Springer.

Hernández, R. (2012). Does continuous assessment in higher education support student learning? Higher Education, 64(4), 489-502.

Holdsworth, A., Watty, K., \& Davies, M. (2009). Developing capstone experiences. Melbourne: Centre for the Study of Higher Education, University of Melbourne.

Horton, J., Macve, R., \& Struyven, G. (2004). Qualitative research: Experiences in using semi-structured interviews. In C. Humphrey \& B. Lee (Eds.), The real life guide to accounting research: a behind-the-scenes view of using qualitative research methods (pp. 339-357). Oxford, UK: Elsevier.

Hughes, C., \& Barrie, S. (2010). Influences on the assessment of graduate attributes in higher education. Assessment \& Evaluation in Higher Education, 35(3), 325-334.

Jackson, D. (2014). Self-assessment of employability skill outcomes among undergraduates and alignment with academic ratings. Assessment \& Evaluation in Higher Education, 39 (1), 53-72.

Jones, A. (2009). Generic attributes as espoused theory: The importance of context. Higher Education, 58(2), 175-191.

Jones, A. (2010). Generic attributes in accounting: The significance of the disciplinary context. Accounting Education: An International Journal, 19(1-2), 5-21.

Kao, G. Y. M. (2013). Enhancing the quality of peer review by reducing student "free riding": Peer assessment with positive interdependence. British Journal of Educational Technology, 44(1), 112-124.

Keller, S., Parker, C. M., \& Chan, C. (2011). Employability skills: Student perceptions of an IS final year capstone subject. Innovation in Teaching and Learning in Information and Computer Sciences, 10(2), 4-15. 
Lai, C.-Y. (2016). Training nursing students' communication skills with online video peer assessment. Computers \& Education, 97, 21-30.

Lawson, R., Taylor, T., Thompson, D., Simpson, L., Freeman, M., Treleaven, L., \& Rohde, F. (2012). Engaging with graduate attributes through encouraging accurate student self-assessment. Asian Social Science, 8(4), 3-12.

ManPowerGroup (2011). Building a high-skilled economy: A new Vietnam. Retrieved from https://bit.ly/2XCRMjz

McMahon, M., Luca, J., \& John, C. (2007). A self-assessment tool to help learners develop teamwork skills. Paper presented at EdMedia: World Conference on Educational Media and Technology. Retrieved from: https://ro.ecu.edu.au/ecuworks/1609/

Merriam, S. B. (2009). Qualitative research: A guide to design and implementation. San Francisco, CA: Jossey-Bass.

MOET (2010). Công văn 2916/BGDĐT-GDĐH huớng dẫn xây dụng và công bố chuẩn đầu ra ngành đào tao. Retrieved from https://bit.ly/2VlKS4I

Musekamp, F., \& Pearce, J. (2015). Assessing engineering competencies: The conditions for educational improvement. Studies in Higher Education, 40(3), 505-524.

Nelson, B. (2002). Striving for quality: Learning, teaching and scholarship. Canberra: Department of Education, Science and Training.

Ng, A. K.-L., Kiang, K.-M., \& Cheung, D. H.-C. (2016). Assessing students' attainment in learning outcomes: A comparison of course-end evaluation and entry-exit surveys. World Journal of Education, 6(3), 56-65.

Nguyen, N. D., Ngoc, N. B., \& Montague, A. (2019). Enhancing graduate work-readiness in Vietnam. In S. Dhakal, V. Prikshat, A. Nankervis, \& J. Burgess (Eds.), The transition from graduation to work (pp. 221-237). Singapore: Springer.

Palmer, S., Holt, D., Hall, W., \& Ferguson, C. (2011). An evaluation of an online student portfolio for the development of engineering graduate attributes. Computer Applications in Engineering Education, 19(3), 447-456.

Quarrie, S. P. (2007). Student peer review as a tool for efficiently achieving subject-specific and generic learning outcomes: Examples in botany at the Faculty of Agriculture, University of Belgrade. Higher Education in Europe, 32(2-3), 203-212.

Rowley, J., Munday, J., \& Polly, P. (2017). Preparing future career ready professionals: A portfolio process to develop critical thinking using digital learning and teaching. Paper presented at the International Conference on Interactive Collaborative Learning, 27-29 Sep, Budapest, Hungary.

Tertiary Education Quality and Standards Agency (2013). Australian qualifications framework. Canberra, Australia: The Australian Qualifications Framework Council.

Tran, L. H. N. (2018). The skills gap of Vietnamese graduates and final-year university students. Journal of Education and Work, 31(7-8), 579-594.

Tremblay, K., Lalancette, D., \& Roseveare, D. (2012). Assessment of higher education learning outcomes. Feasibility study report. OECD. Retrieved from: https://bit.ly/ 2IRTRnB

World Bank (2008). Vietnam: Higher education and skills for growth. Retrieved from http s://openknowledge.worldbank.org/handle/10986/7814

Ya-hui, S., \& Li-yia, F. (2008). Assessing graduate attributes for employability in the context of lifelong learning: The holistic approach. US-China Education Review, 5(11). Retrieved from: https://files.eric.ed.gov/fulltext/ED503876.pdf

Yin, H., Lu, G., \& Wang, W. (2014). Unmasking the teaching quality of higher education: Students' course experience and approaches to learning in China. Assessment \& Evaluation in Higher Education, 39(8), 949-970. 
Yin, R. K. (2009). Case study research, design \& methods (4th edn). Thousand Oaks, CA: Sage.

Binder, J. F., Baguley, T., Crook, C., \& Miller, F. (2015). The academic value of internships: Benefits across disciplines and student backgrounds. Contemporary Educational Psychology, 41(April), 73-82.

Borghetti, C., \& Beaven, A. (2017). Lingua francas and learning mobility: Reflections on students' attitudes and beliefs towards language learning and use. International Journal of Applied Linguistics, 27(1), 221-241.

Bourdieu, P. (1989). Social space and symbolic power. Sociological Theory, 7(1), 14-25.

Bourdieu, P., \& Wacquant, L. (1992). An invitation to reflexive sociology. Cambridge, UK: Polity.

Clarke, M. (2017). Rethinking graduate employability: The role of capital, individual attributes and context. Studies in higher education, 43(11), 1923-1937.

Elo, S., \& Kyngäs, H. (2008). The qualitative content analysis process. Journal of Advanced Nursing, 62(1), 107-115.

Fugate, M., Kinicki, A. J., \& Ashforth, B. E. (2004). Employability: A psycho-social construct, its dimensions, and applications. Journal of Vocational Behavior, 65(1), 14-38.

Gault, J., Leach, E., \& Duey, M. (2010). Effects of business internships on job marketability: the employers' perspective. Education + Training, 52(1), 76-88.

Gilbert, B. L., Banks, J., Houser, J. H., Rhodes, S. J., \& Lees, N. D. (2014). Student development in an experiential learning program. Journal of College Student Development, 55(7), 707-713.

Jackson, D. (2015). Employability skill development in work-integrated learning: Barriers and best practice. Studies in Higher Education, 40(2), 350-367.

Khalil, O. E. (2015). Students' experiences with the business internship program at Kuwait University. The International Journal of Management Education, 13(3), 202-217.

King, R., Findlay, A., \& Ahrens, J. (2010). International student mobility literature review. Retrieved from: https://core.ac.uk/download/pdf/20458001.pdf

Lam, T., \& Ching, L. (2007). An exploratory study of an internship program: The case of Hong Kong students. International Journal of Hospitality Management, 26(2), 336-351.

Lave, J., \& Wenger, E. (1991). Situated learning: Legitimate peripheral participation. Cambridge, UK: Cambridge University Press.

Li, S., Whalley, J., \& Xing, C. (2014). China's higher education expansion and unemployment of college graduates. China Economic Review, 30(Sep), 567-582.

McQuaid, R. W., \& Lindsay, C. (2005). The concept of employability. Urban Studies, 42 (2), 197-219.

Merriam, S. B. (2009). Qualitative research: A guide to design and implementation. San Francisco, CA: Jossey-Bass.

Montano, D. E., \& Kasprzyk, D. (2015). Theory of reasoned action, theory of planned behavior, and the integrated behavioral model. In K. Glanz, B. K. Rimer, \& K. Viswanath (Eds.), Health behavior: Theory, research and practice (5th edn, pp. 95-124). San Francisco, CA: Jossey-Bass.

Narayanan, V., Olk, P. M., \& Fukami, C. V. (2010). Determinants of internship effectiveness: An exploratory model. Academy of Management Learning \& Education, 9(1), 61-80.

Navarro, D., \& Thornton, K. (2011). Investigating the relationship between belief and action in self-directed language learning. System, 39(3), 290-301.

Nunley, J. M., Pugh, A., Romero, N., \& SealsJr, R. A. (2016). College major, internship experience, and employment opportunities: Estimates from a résumé audit. Labour Economics, 38(Jan), 37-46. 
Odio, M., Sagas, M., \& Kerwin, S. (2014). The influence of the internship on students' career decision making. Sport Management Education Journal, 8(1), 46-57.

Oliver, B. (2015). Redefining graduate employability and work-integrated learning: Proposals for effective higher education in disrupted economies. Journal of Teaching and Learning for Graduate Employability, 6(1), 56-65.

Read, P., Hughes, J. D., Blagrove, R., Jeffreys, I., Edwards, M., \& Turner, A. N. (2017). Characteristics and experiences of interns in strength and conditioning. Journal of Sports Sciences, 35(3), 269-276.

Rothman, M., \& Sisman, R. (2016). Internship impact on career consideration among business students. Education + Training, 58(9), 1003-1013.

Schmidt, M. K. (2017). Personal and professional development through internship engagement. In T. Newman \& A. Schmitt (Eds.), Field-based learning in family life education (pp. 39-49). Cham: Springer.

Simiyu, R. R., Okaka, F. O., \& Omondi, P. (2015). Geography students' assessment of internship experience at a Kenyan university. Journal of Geography in Higher Education, 39(3), 343-355.

Son, T. (2015). Vietnam to get tough on bribery for job, promotion: Officials. Thanhnien News, 30 January. Retrieved from https://bit.ly/2SArdZk

Tomlinson, M. (2017). Forms of graduate capital and their relationship to graduate employability. Education + Training, 59(4), 338-352.

Tran, L. H. N. (2018a). Game of blames: Higher education stakeholders' perceptions of causes of Vietnamese graduates' skills gap. International Journal of Educational Development, 62(Sep), 302-312.

Tran, L. H. N. (2018b). The skills gap of Vietnamese graduates and final-year university students. Journal of Education and Work, 31(7-8), 579-594.

Tran, L. H. N., \& Nguyen, T. M. D. (2018). Internship-related learning outcomes and their influential factors: The case of Vietnamese tourism and hospitality students. Education + Training, 60(1), 69-81.

Tuoi Tre News (2012). Corruption in Vietnam is serious, blatant, rampant. Retrieved from https://bit.ly/2W4eGzS

Wenger, E. (2010). Communities of practice and social learning systems: The career of a concept. In C. Blackmore (Ed.), Social learning systems and communities of practice (pp. 179-198). London: Springer.

Wu, C.-C. (2011). High graduate unemployment rate and Taiwanese undergraduate education. International Journal of Educational Development, 31(3), 303-310.

Yorke, M. (2006). Employability in higher education: What it is, what it is not. Retrieved from https://bit.ly/22VzZS0.

Al-Ansari, A., Al-Harbi, F., AbdelAziz, W., AbdelSalam, M., El Tantawi, M. M., \& ElRefae, I. (2016). Factors affecting student participation in extra-curricular activities: A comparison between two Middle Eastern dental schools. The Saudi Dental Journal, 28(1), 36-43.

Al-Mahmood, R., \& Gruba, P. (2007). Approaches to the implementation of generic graduate attributes in Australian ICT undergraduate education. Computer Science Education, 17(3), 171-185. doi: 10.1080/08993400701538054

Barrie, S., Hughes, C., Smith, C., \& Thomson, K. (2009). The national graduate attributes project: Key issues to consider in the renewal of learning and teaching experiences to foster graduate attributes. Sydney: The University of Sydney.

Bodewig, C., \& Badiani-Magnusson, R. (2014). Skilling up Vietnam: Preparing the workforce for a modern market economy. Washington, DC: World Bank Publications. 
Clark, G., Marsden, R., Whyatt, J. D., Thompson, L., \& Walker, M. (2015). "It's everything else you do...": Alumni views on extracurricular activities and employability. Active Learning in Higher Education, 16(2), 133-147.

De Lisle, J. (2011). The benefits and challenges of mixing methods and methodologies: Lessons learnt from implementing qualitatively led mixed methods research designs in Trinidad and Tobago. Caribbean Curriculum, 18, 87-120. Retrieved from https://bit.ly/ 2JbhJUU.

De Vaus, D. A. (2014). Surveys in social research. Abingdon, UK: Routledge.

Elo, S., \& Kyngäs, H. (2008). The qualitative content analysis process. Journal of Advanced Nursing, 62(1), 107-115.

Ho Chi Minh Communist Youth Union (2019). Ho Chi Minh Communist Youth Union. Retrieved from http://english.doanthanhnien.vn/.

Hordósy, R., \& Clark, T. (2018). Beyond the compulsory: A critical exploration of the experiences of extracurricular activity and employability in a northern red brick university. Research in Post-Compulsory Education, 23(3), 414-435.

Kalles, S., \& Ryan, T. G. (2015). Service-learning: Promise and possibility in post-secondary education. International Journal of Progressive Education, 11(1), 132-148.

Khan, S. A. R., \& Zhang, Y. (2017). The effective role of visiting lecturers in the courses of supply chain management. American Journal of Traffic and Transportation Engineering, 2(6), 104-109.

Lau, H.-H., Hsu, H.-Y., Acosta, S., \& Hsu, T.-L. (2014). Impact of participation in extracurricular activities during college on graduate employability: An empirical study of graduates of Taiwanese business schools. Educational Studies, 40(1), 26-47.

Lindorff, M. (2011). Skills gaps in Australian firms. Journal of Vocational Education and Training, 63(2), 247-259.

Litecky, C. R., Arnett, K. P., \& Prabhakar, B. (2004). The paradox of soft skills versus technical skills in IS hiring. Journal of Computer Information Systems, 45(1), 69-76.

Mestechkina, T., Son, N. D., \& Shin, J. Y. (2014). Parenting in Vietnam. In H. Selin (Ed.), Parenting across cultures (pp. 47-57). Dordrecht, Netherlands: Springer.

Nickson, D., Warhurst, C., Commander, J., Hurrell, S. A., \& Cullen, A. M. (2012). Soft skills and employability: Evidence from UK retail. Economic and Industrial Democracy, 33(1), 65-84.

Osman, K. (2011). The inculcation of generic skills through service learning experience among science student teachers. Procedia - Social and Behavioral Sciences, 18, 148-153. doi: 10.1016/j.sbspro.2011.05.022

Roulin, N., \& Bangerter, A. (2013). Students' use of extra-curricular activities for positional advantage in competitive job markets. Journal of Education and Work, 26(1), 21-47.

Scarinci, J., \& Pearce, P. (2012). The perceived influence of travel experiences on learning generic skills. Tourism Management, 33(2), 380-386.

Sepahpanah, M., Zarafshani, K., Mirakzade, A., \& Rosch, D. M. (2013). Service learning processes and challenges in Iran: A case study. NACTA Journal, 57(3a), 36-39.

Tertiary Education Quality and Standards Agency (2013). Australian qualifications framework. Sydney: The Australian Qualifications Framework Council.

The Quality Assurance Agency for Higher Education (2014). The frameworks for higher education qualifications of UK degree-awarding bodies. Retrieved from: www.qaa.ac.uk/ docs/qaa/quality-code/qualifications-frameworks.pdf

Thompson, L. J., Clark, G., Walker, M., \& Whyatt, J. D. (2013). "It's just like an extra string to your bow": Exploring higher education students' perceptions and experiences of extracurricular activity and employability. Active Learning in Higher Education, 14(2), 135-147. 
Tran, L. H. N. (2018). Game of blames: Higher education stakeholders' perceptions of causes of Vietnamese graduates' skills gap. International Journal of Educational Development, 62(Sep), 302-312.

Tran, T. T. (2015). Is graduate employability the "whole-of-higher-education-issue"? Journal of Education and Work, 28(3), 207-227. doi: 10.1080/13639080.2014.900167

UK Commission for Employment and Skills (2016). Employer skills survey 2015: UK results. Retrieved from https://bit.ly/2PpNxFj

Williams, B., Onsman, A., \& Brown, T. (2010). Exploratory factor analysis: A five-step guide for novices. Australasian Journal of Paramedicine, 8(3), 1-13.

Yorke, M. (2006). Employability in higher education: What it is, what it is not. Retrieved from https://bit.ly/22VzZS0.

Al-Mahmood, R., \& Gruba, P. (2007). Approaches to the implementation of generic graduate attributes in Australian ICT undergraduate education. Computer Science Education, 17(3), 171-185.

Anthony, S., \& Garner, B. (2016). Teaching soft skills to business students: An analysis of multiple pedagogical methods. Business and Professional Communication Quarterly, 79 (3), 360-370.

Barrie, S., Hughes, C., Smith, C., \& Thomson, K. (2009). The national graduate attributes project: Key issues to consider in the renewal of learning and teaching experiences to foster graduate attributes. Sydeney: Australian Learning and Teaching Council.

Browne, K. (2005). Snowball sampling: Using social networks to research non-heterosexual women. International Journal of Social Research Methodology, 8(1), 47-60.

Carter, L., Ruskin, J., \& Cassilles, A. (2017). Three modes of work-integrated learning: stories of success. In L. N. Wood \& Y. A. Breyer (Eds.), Success in higher education (pp. 203-215). Singapore: Springer.

Choudaha, R., Chang, L., \& Kono, Y. (2014). International student mobility trends 2013: Towards responsive recruitment strategies. World Education News \& Reviews, 26(2), 1-8.

Chowdhury, T. A., \& Miah, M. K. (2016). Employability skills for entry-level human resources management positions: Perceptions of students and employers. Australian Journal of Career Development, 25(2), 55-68.

Elo, S., \& Kyngäs, H. (2008). The qualitative content analysis process. Journal of Advanced Nursing, 62(1), 107-115.

Hayhoe, R., Li, J., Lin, J., \& Zha, Q. (2012). Portraits of $21^{\text {st }}$ century Chinese universities: In the move to mass higher education (Vol. 30). Dordrecht, Netherlands: Springer Science \& Business Media.

Heffernan, T. A., \& Heffernan, A. (2018). Language games: University responses to ranking metrics. Higher Education Quarterly, 72(1), 29-39.

Horton, J., Macve, R., \& Struyven, G. (2004). Qualitative research: Experiences in using semi-structured interviews. In C. Humphrey \& B. Lee (Eds.), The real life guide to accounting research: A behind-the-scenes view of using qualitative research methods (pp. 339-357). Oxford, UK: Elsevier.

Jackson, D. (2015). Employability skill development in work-integrated learning: Barriers and best practice. Studies in Higher Education, 40(2), 350-367.

Jackson, D. (2018). Developing graduate career readiness in Australia: Shifting from extracurricular internships to work-integrated learning. International Journal of Work-Integrated Learning, 19(1), 23-35.

Khan, S. A. R., \& Zhang, Y. (2017). The effective role of visiting lecturers in the courses of supply chain management. American Journal of Traffic and Transportation Engineering, 2(6), 104-109. 
Kohlbry, P. W. (2016). The impact of international service-learning on nursing students' cultural competency. Journal of Nursing Scholarship, 48(3), 303-311.

Lebeau, Y., Stumpf, R., Brown, R., Lucchesi, M. A. S., \& Kwiek, M. (2012). Who shall pay for the public good? Comparative trends in the funding crisis of public higher education. Compare: A Journal of Comparative and International Education, 42(1), 137157.

Mason, G., Williams, G., \& Cranmer, S. (2009). Employability skills initiatives in higher education: What effects do they have on graduate labour market outcomes? Education Economics, 17(1), 1-30.

Maxwell, G., Scott, B., Macfarlane, D., \& Williamson, E. (2009). Employers as stakeholders in postgraduate employability skills development. International Journal of Management, 8(2), 13-23.

Merriam, S. B. (2009). Qualitative research: A guide to design and implementation. San Francisco, CA: Jossey-Bass.

Mok, K. H., \& Jiang, J. (2018). Massification of higher education and challenges for graduate employment and social mobility: East Asian experiences and sociological reflections. International Journal of Educational Development, 63(Nov), 44-51.

Murray, M., Ross, A., Blaney, N., \& Adamson, L. (2015). Mentoring undergraduate civil engineering students. Proceedings of the ICE-Management, Procurement and Law, 168 (4), 189-198.

Osman, K. (2011). The inculcation of generic skills through service learning experience among science student teachers. Procedia-Social and Behavioral Sciences, 18, 148-153.

Sepahpanah, M., Zarafshani, K., Mirakzade, A., \& Rosch, D. M. (2013). Service learning processes and challenges in Iran: A case study. NACTA Journal, 57(3a), 36-39.

Singh, A., \& Jaykumar, P. (2019). On the road to consensus: Key soft skills required for youth employment in the service sector. Worldwide Hospitality and Tourism Themes, 11 (1), 10-24. doi: 10.1108/WHATT-10-2018-0066

Soh, K. (2017). The seven deadly sins of world university ranking: A summary from several papers. Journal of Higher Education Policy and Management, 39(1), 104-115.

Tomlinson, M. (2018). Employers and universities: Conceptual dimensions, research evidence and implications. Higher Education Policy. doi: 10.1057/s41307-018-0121-9

Tran, L. H. N., \& Nguyen, T. M. D. (2018). Internship-related learning outcomes and their influential factors: The case of Vietnamese tourism and hospitality students. $E d u$ cation + Training, 60(1), 69-81.

Tran, T. T. (2013). Limitation on the development of skills in higher education in Vietnam. Higher Education, 65(5), 631-644.

van Hoek, R., Godsell, J., \& Harrison, A. (2011). Embedding "insights from industry" in supply chain programmes: The role of guest lecturers. Supply Chain Management: An International Journal, 16(2), 142-147.

Yang, L. (2018). Higher education expansion and post-college unemployment: Understanding the roles of fields of study in China. International Journal of Educational Development, 62(Sep), 62-74.

Yin, R. K. (2009). Case study research, design o methods (4th edn). Thousand Oaks, CA: Sage.

Barrie, S., Hughes, C., Smith, C., \& Thomson, K. (2009). The national graduate attributes project: Key issues to consider in the renewal of learning and teaching experiences to foster graduate attributes. Sydney: The University of Sydney.

Bodewig, C., \& Badiani-Magnusson, R. (2014). Skilling up Vietnam: Preparing the workforce for a modern market economy. Washington, DC: World Bank Publications. 
Christie, H., Tett, L., Cree, V. E., Hounsell, J., \& McCune, V. (2008). "A real rollercoaster of confidence and emotions": Learning to be a university student. Studies in Higher Education, 33(5), 567-581.

de la Harpe, B., \& David, C. (2012). Major influences on the teaching and assessment of graduate attributes. Higher Education Research \& Development, 31(4), 493-510.

de la Harpe, B., \& Radloff, A. (2008). Developing graduate attributes for lifelong learninghow far have we got? Paper presented at the $5^{\text {th }}$ International Lifelong Learning Conference, 16-19 June, Yeppoon, Australia.

Filsecker, M., \& Kerres, M. (2014). Engagement as a volitional construct: A framework for evidence-based research on educational games. Simulation \& Gaming, 45(4-5), 450-470.

Fredricks, J. A., Blumenfeld, P. C., \& Paris, A. H. (2004). School engagement: Potential of the concept, state of the evidence. Review of Educational Research, 74(1), 59-109.

Furlong, M. J., Whipple, A. D., Jean, G. S., Simental, J., Soliz, A., \& Punthuna, S. (2003). Multiple contexts of school engagement: Moving toward a unifying framework for educational research and practice. The California School Psychologist, 8(1), 99-113.

Hu, S., \& Kuh, G. D. (2002). Being (dis)engaged in educationally purposeful activities: The influences of student and institutional characteristics. Research in Higher Education, $43(5), 555-575$.

Jimerson, S. R., Campos, E., \& Greif, J. L. (2003). Toward an understanding of definitions and measures of school engagement and related terms. The California School Psychologist, $8(1), 7-27$.

Johnson, G. M. (2005). Student alienation, academic achievement, and WebCT use. Journal of Educational Technology \& Society, 8(2), 179-189.

Kahu, E. R. (2013). Framing student engagement in higher education. Studies in Higher Education, 38(5), 758-773.

Kahu, E. R., \& Nelson, K. (2018). Student engagement in the educational interface: understanding the mechanisms of student success. Higher Education Research o Development, 37(1), 58-71.

Kimbark, K., Peters, M. L., \& Richardson, T. (2017). Effectiveness of the student success course on persistence, retention, academic achievement, and student engagement. Community College Journal of Research and Practice, 41(2), 124-138.

Klauda, S. L., \& Guthrie, J. T. (2015). Comparing relations of motivation, engagement, and achievement among struggling and advanced adolescent readers. Reading and Writing, 28(2), 239-269.

Konold, T., Cornell, D., Jia, Y., \& Malone, M. (2018). School climate, student engagement, and academic achievement: A latent variable, multilevel multi-informant examination. AERA Open, 4(4), 1-17.

Krause, K. L., \& Coates, H. (2008). Students' engagement in first-year university. Assessment \& Evaluation in Higher Education, 33(5), 493-505.

Kuh, G. D. (2001). The national survey of student engagement: Conceptual framework and overview of psychometric properties. Bloomington, IN: Indiana University Center for Postsecondary Research. Retrieved from https://bit.ly/2HRUHAq.

Kuh, G. D. (2007). How to help students achieve. Chronicle of Higher Education, 53(41), B12-B13. Retrieved from www.chronicle.com/article/How-to-Help-Students-Achieve/ 31980

Kuh, G. D. (2009). What student affairs professionals need to know about student engagement. Journal of College Student Development, 50(6), 683-706. 
Lessiter, J., Freeman, J., Keogh, E., \& Davidoff, J. (2001). A cross-media presence questionnaire: The ITC-Sense of Presence Inventory. Presence: Teleoperators \& Virtual Environments, 10(3), 282-297.

Libbey, H. P. (2004). Measuring student relationships to school: Attachment, bonding, connectedness, and engagement. Journal of School Health, 74(7), 274-283.

Linnenbrink-Garcia, L., Rogat, T. K., \& Koskey, K. L. (2011). Affect and engagement during small group instruction. Contemporary Educational Psychology, 36(1), 13-24.

Lisle, J. D. (2011). The benefits and challenges of mixing methods and methodologies: Lessons learnt from implementing qualitatively led mixed methods research designs in Trinidad and Tobago. Caribbean Curriculum, 18, 87-120.

Macfarlane, B., \& Tomlinson, M. (2017). Critiques of student engagement. Higher Education Policy, 30(1), 5-21.

Mann, S. J. (2001). Alternative perspectives on the student experience: Alienation and engagement. Studies in Higher Education, 26(1), 7-19.

Nguyen, M. T. (2011). Vietnamese students' employability skills. International Education Studies, 4(4), 175.

Nguyen, N. D., Ngoc, N. B., \& Montague, A. (2019). Enhancing graduate work-readiness in Vietnam. In S. Dhakal, V. Prikshat, A. Nankervis, \& J. Burgess (Eds.), The transition from graduation to work (pp. 221-237). Singapore: Springer.

Nguyen, T. N. (2018). Issues in soft skills development for Vietnamese students in current undergraduate programs. Tap chi Khoa hoc, 15(7), 114-124. Retrieved from https:// bit.ly/2ZHIMNc

Radloff, A., \& Coates, H. (2010). Doing more for learning: Enhancing engagement and outcomes: Australasian survey of student engagement: Australasian student engagement report. Camberwell, Australia: Australian Council for Educational Research (ACER).

Reeve, J., \& Tseng, C.-M. (2011). Agency as a fourth aspect of students' engagement during learning activities. Contemporary Educational Psychology, 36(4), 257-267.

Shuck, B., \& Wollard, K. (2010). Employee engagement and HRD: A seminal review of the foundations. Human Resource Development Review, 9(1), 89-110.

The Higher Education Funding Council for England (HEFCE) (2008). Tender for a Study into Student Engagement. Bristol: Higher Education Funding Council for England.

Thomas, L. (2002). Student retention in higher education: The role of institutional habitus. Journal of Education Policy, 17(4), 423-442.

Toshalis, E., \& Nakkula, M. J. (2012). Motivation, engagement, and student voice. Retrieved from: https://studentsatthecenterhub.org/wp-content/uploads/2012/04/ Exec-Toshalis-Nakkula-032312.pdf

Tran, L. H. N. (2017). Developing employability skills via extra-curricular activities in Vietnamese universities: Student engagement and inhibitors of their engagement. Journal of Education and Work, 30(8), 854-867.

Tran, L. H. N. (2018). The skills gap of Vietnamese graduates and final-year university students. Journal of Education and Work, 31(7-8), 579-594.

Tran, L. T., Le, T. T. T., \& Nguyen, N. T. (2014). Curriculum and pedagogy. In Higher education in Vietnam: Flexibility, Mobility and practicality in the global knowledge economy (pp. 86-107). London: Palgrave Macmillan.

Tran, T. T. (2015). Is graduate employability the "whole-of-higher-education-issue"? Journal of Education and Work, 28(3), 207-227.

Tsai, C. T. L. (2006). The influence of Confucianism on women's leisure in Taiwan. Leisure Studies, 25(4), 469-476. doi: 10.1080/02614360600898177 
Wang, M.-T., \& Holcombe, R. (2010). Adolescents' perceptions of school environment, engagement, and academic achievement in middle school. American Educational Research Journal, 47(3), 633-662.

Wang, M. T., \& Fredricks, J. A. (2014). The reciprocal links between school engagement, youth problem behaviors, and school dropout during adolescence. Child Development, 85(2), 722-737.

Al-Mahmood, R., \& Gruba, P. (2007). Approaches to the implementation of generic graduate attributes in Australian ICT undergraduate education. Computer Science Education, 17(3), 171-185.

Ang, L., D'Alessandro, S., \& Winzar, H. (2014). A visual-based approach to the mapping of generic skills: its application to a marketing degree. Higher Education Research o Development, 33(2), 181-197.

Anh, H. (2014). University lecturers receive \$183-368 monthly salary: Report. Vietnamenet. Retrieved from https://bit.ly/2W9Hcjy

Attard, A., Di Iorio, E., Geven, K., \& Santa, R. (2010). Student-centred learning: Toolkit for students, staff and higher education institutions. Retrieved from https://bit.ly/ 2UCtDYG

B-HERT (2003).Developing generic skills: Examples of best practice. B-HERT News. Retrieved from https://bit.ly/2GAJ9QL

Barrie, S., Hughes, C., Smith, C., \& Thomson, K. (2009). The national graduate attributes project: Key issues to consider in the renewal of learning and teaching experiences to foster graduate attributes. Sydney: The University of Sydney.

Barrie, S. C. (2006). Understanding what we mean by the generic attributes of graduates. Higher Education, 51(2), 215-241.

Barrie, S. C. (2007). A conceptual framework for the teaching and learning of generic graduate attributes. Studies in Higher Education, 32(4), 439-458.

Brodie, L. (2011). Delivering key graduate attributes via teams working in virtual space. International Journal of Emerging Technologies in Learning (iJET), 6(3), 5-11.

Chapman, E., \& O'Neill, M. (2010). Defining and assessing generic competencies in Australian universities: Ongoing challenges. Education Research and Perspectives, 37(1), 105.

Danish Government (2008). Qualifications framework for Danish higher education. Retrieved from https://bit.ly/2URzxtC.

de la Harpe, B., \& David, C. (2012). Major influences on the teaching and assessment of graduate attributes. Higher Education Research \& Development, 31(4), 493-510.

de la Harpe, B., \& Radloff, A. (2008). Developing graduate attributes for lifelong learninghow far have we got? Paper presented at the 5th International Lifelong Learning Conference, 16-19 June, Yeppoon, Australia.

Do, H. M. (2014). Towards more flexible organization. In L. T. Tran, S. Marginson, H. M. Do, Q. T. N. Do, T. T. T. Le, N. T. Nguyen, T. T. P. Vu, T. N. Pham, H. T. L. Nguyen, \& T. T. H. Ho (Eds.), Higher education in Vietnam: Flexibility, mobility and practicality in the global knowledge economy (pp. 54-85). New York, NY: Palgrave MacMilan.

Dollinger, M., Coates, H., Bexley, E., Croucher, G., \& Naylor, R. (2018). Framing international approaches to university-industry collaboration. Policy Reviews in Higher Education, 2(1), 105-127. doi: 10.1080/23322969.2018.1424560

Ho Chi Minh Communist Youth Union (2019). Ho Chi Minh Communist Youth Union. Retrieved from http://english.doanthanhnien.vn/

Hughes, C., \& Barrie, S. (2010). Influences on the assessment of graduate attributes in higher education. Assessment \& Evaluation in Higher Education, 35(3), 325-334. 
Jackson, D. (2017). Developing pre-professional identity in undergraduates through workintegrated learning. Higher Education, 74(5), 833-853.

Jackson, D. (2018). Developing graduate career readiness in Australia: Shifting from extracurricular internships to work-integrated learning. International Journal of Work-Integrated Learning, 19(1), 23-35.

Jackson, D., \& Collings, D. (2018). The influence of work-integrated learning and paid work during studies on graduate employment and underemployment. Higher Education, 76(3), 403-425. doi: 10.1007/s10734-017-0216-z

Jones, A. (2009). Generic attributes as espoused theory: The importance of context. Higher Education, 58(2), 175-191.

Lam, A. (2011). University-industry collaboration: careers and knowledge governance in hybrid organisational space. International Journal of Strategic Business Alliances, 2(1-2), $135-145$.

Lawson, R., Taylor, T., Fallshaw, E., Summers, J., Kinash, S., French, E., \& AngusLeppan, T. (2013). Hunters and gatherers: Strategies for curriculum mapping and data collection for assuring learning. Retrieved from https://bit.ly/2DqAWgk

Marginson, S. (2011). Higher education in East Asia and Singapore: Rise of the Confucian model. Higher Education, 61(5), 587-611.

MOET (2010a). Công văn 2916/ BGDĐT-GDĐH hương dẫn xây dưng và công bố chuẩn đầu ra ngành đào tao. Retrieved from https://bit.ly/2VlKS4I

MOET (2010b). Quyết định: Quy định về việc xác định chỉ tiêu tuyển sinh, quy trình đăng ký, thông báo chỉ tiêu tuyển sinh, kiểm tra và xủ lý việc thẹc hiện các quy định về xác định chỉ tiêu tuyển sinh đại học, sau đại học, cao đẳng và trung cấp chuyên nghiệp. (795/QD$B G D Ð T)$. Retrieved from https://bit.ly/2ZI4DD4

Napier, N. K., \& Hoang, V. Q. (2013). What we see, why we worry, why we hope: Vietnam going forward. Boise, ID: Boise State University CCI Press.

Nguyen, T. L. H. (2013). Middle-level academic management: A case study on the roles of the heads of department at a Vietnamese university. Tertiary Education and Management, 19(1), 1-15. doi: 10.1080/13583883.2012.724704

Pitman, T., \& Broomhall, S. (2009). Australian universities, generic skills and lifelong learning. International Journal of Lifelong Education, 28(4), 439-458.

Prabhu, B. V., \& Kudva, S. A. (2016). Success of student internship in engineering industry: A faculty perspective. Higher Education for the Future, 3(2), 164-182. doi: $10.1177 / 2347631116650550$

Rampersad, G. C. (2015). Developing university-business cooperation through work-integrated learning. International Journal of Technology Management, 68(3-4), 203-227.

Rowe, A. D., \& Zegwaard, K. E. (2017). Developing graduate employability skills and attributes: Curriculum enhancement through work-integrated learning. Asia-Pacific Journal of Cooperative Education, 18(2), 87-99.

Schlesinger, W., Cervera, A., \& Pérez-Cabañero, C. (2017). Sticking with your university: The importance of satisfaction, trust, image, and shared values. Studies in Higher Education, 42(12), 2178-2194.

Sharda, H., \& Butler, A. (2004). The role of alumni in increasing university/industry interaction. In Creating Flexible Learning Environments: Proceedings of the 15th Australasian Conference for the Australasian Association for Engineering Education and the 10th Australasian Women in Engineering Forum. Toowoomba, Australia: Australasian Association for Engineering Education.

Shek, D. T., \& Chak, Y. L. (2019). Perceived changes and benefits of a service-learning subject for underprivileged children in Shanghai: Views of university students. In D. T. 
L. Shek, G. Ngai, \& S. C. F. Chan (Eds.), Service-learning for youth leadership: The case of Hong Kong (pp. 33-47). Singapore: Springer.

Thai Government (2006). National qualifications framework for higher education in Thailand. Retrieved from: https://bit.ly/2DsbFSX

Tran, L. H. N., Phan, T. N. P., \& Tran, L. K. H. (2018). Implementing the studentcentred teaching approach in Vietnamese universities: The influence of leadership and management practices on teacher engagement. Educational Studies. doi: 10.1080/ 03055698.2018 .1555453

Tran, L. T., Le, T. T. T., \& Nguyen, N. T. (2014). Curriculum and pedagogy. In Higher education in Vietnam: Flexibility, mobility and practicality in the global knowledge economy (pp. 86-107). London: Palgrave Macmillan.

Tran, T. T. (2015). Is graduate employability the "whole-of-higher-education-issue"? Journal of Education and Work, 28(3), 207-227.

Tremblay, K., Lalancette, D., \& Roseveare, D. (2012). Assessment of higher education learning outcomes. OECD. Retrieved from: https://bit.ly/2IRTRnB

Vietnamese Government (2012). Luật giáo dụ đại học. Retrieved from https://bit.ly/ 2GNGV24

Vogler, J. S., Thompson, P., Davis, D. W., Mayfield, B. E., Finley, P. M., \& Yasseri, D. (2018). The hard work of soft skills: augmenting the project-based learning experience with interdisciplinary teamwork. Instructional Science, 46(3), 457-488.

Vu, T. P. A. (2014). Tự chủ đại học ở Việt Nam: Thiếu thực chất. Tia Sang, 22 August. Retrieved from https://bit.ly/2IU59rC 